\title{
Film Classification in Canada and the United States: The Freedom of Government Control?
}

\author{
by
}

Timothy Covell

A thesis submitted to the Faculty of Graduate and Postdoctoral Affairs in partial fulfillment of the requirements for the degree of

Master of Arts

in

Canadian Studies

Carleton University

Ottawa, Ontario

(C) 2015 Timothy Covell 


\begin{abstract}
The American film industry voluntarily classifies films, using the well-known MPAA ratings. The industry claims this is preferable and more liberal than the alternative approach of government classification. In Canada, film classification is mandatory in most jurisdictions, and performed by provincial governments. This thesis demonstrates that the Canadian government controlled mandatory ratings systems for films results in more liberal film ratings than the voluntary system in the United States, for most mainstream films. An analysis of one hundred recent releases and case studies support this conclusion.

The histories and operations of the agencies in Canada and the United States, and differences among the provinces, are reviewed to identify factors leading to the different ratings, as well as challenges to the ratings systems. A key factor may be that Canadian agencies classify films not subject to MPAA classification.
\end{abstract}




\section{Acknowledgements}

It has been twenty years since I developed an interest in film censorship and started working towards a Master's Degree. Many people have helped along the way.

At the beginning was Jacqueline Jenkins, now at the University of Calgary. I'd also like to thank George McKnight, José Sanchez, Charles O'Brien, and others in Film Studies at Carleton.

Peter Hodgins of Canadian Studies assisted with various drafts of this thesis and other work in my area of interest. I am grateful for his assistance and direction.

I am fortunate to have received advice and encouragement from André Loiselle for several years, on various projects, through my Film and Canadian Studies degrees. As my advisor, he has been patient, flexible, and generally great to work with.

Thanks to Dorothyanne for support and encouragement with this and other efforts, and for challenging me to become a better writer and a better person.

Thanks to Nancy for putting up with me being busy writing much of time, and for lots of movie nights, including some that were not research related.

My parents, Katherine Covell and Brian Howe, retired university professors, have long provided great examples of academic achievement, and served as unofficial readers and advisors on this thesis. I appreciated their assistance, and am grateful that I was never in their classes.

There is another party I would like to thank, but cannot mention by name due to a court order. I trust they will never think they were forgotten. 


\section{Table of Contents}

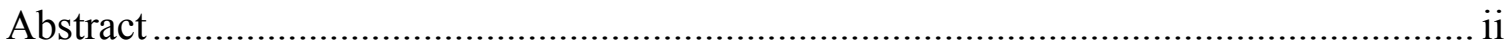

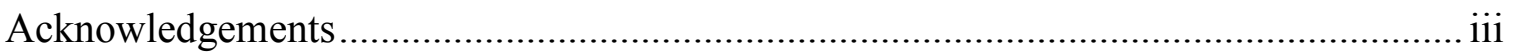

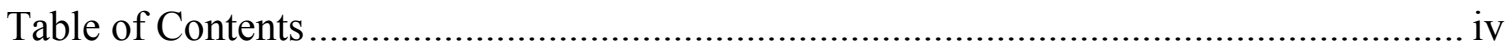

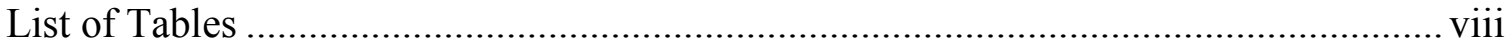

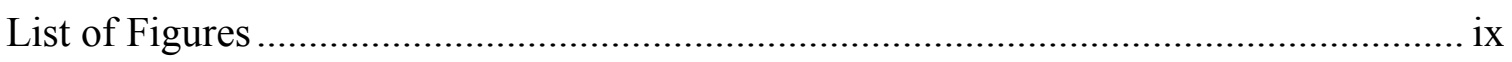

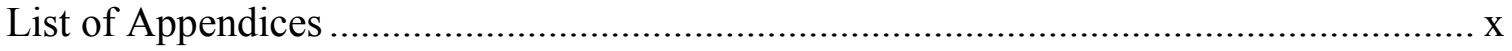

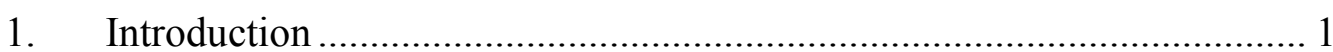

1.1. American and Canadian Ratings Differences ...................................... 2

1.2. Rating Systems Background ………………................................... 3

1.3. Ratings Systems Relevance ................................................................. 5

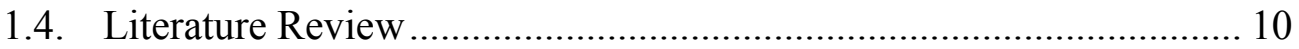

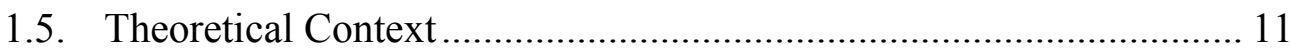

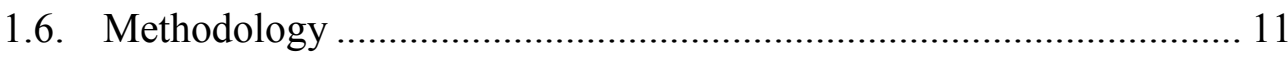

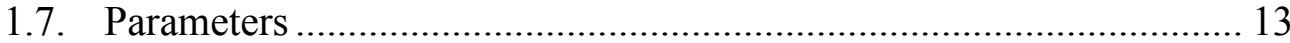

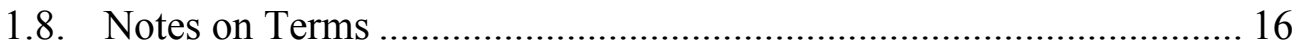

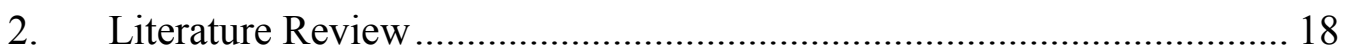

2.1. International Film Ratings Comparisons ………………………….... 18

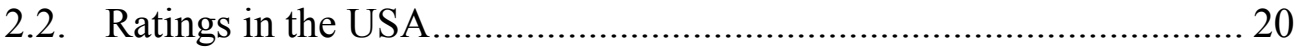

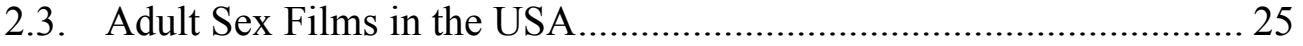

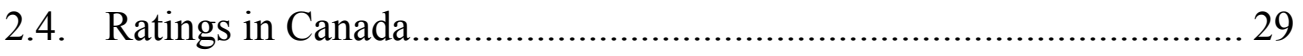


2.5. Adult Sex Films in Canada. 31

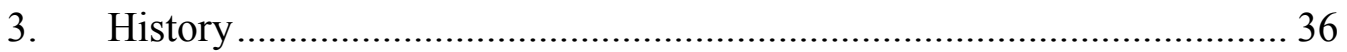

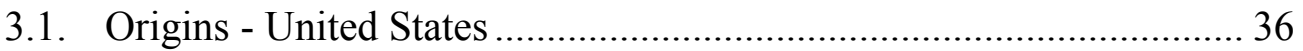

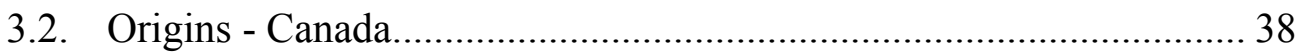

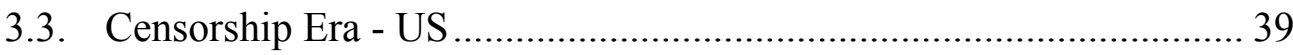

3.4. Censorship Era - Canada ............................................................ 41

3.5. Production Code Era - United States............................................... 43

3.6. Production Code Era - Canada ..................................................... 47

4. Legalization of Adult Sex Films ....................................................... 52

4.1. Early History of Adult Sex Films in the USA.................................. 53

4.2. Development of the Adult Sex Feature ........................................... 54

4.3. The Decline of the Adult Sex Feature ................................................ 59

4.4. Early History of Adult Sex Films in Canada.................................... 62

4.5. Acceptance of Adult Sex Films in Canada....................................... 67

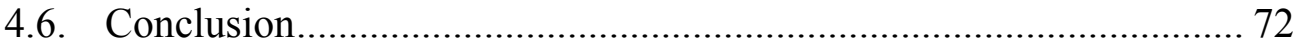

5. Structure and Operation of the Agencies ...................................... 73

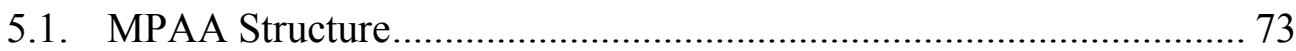

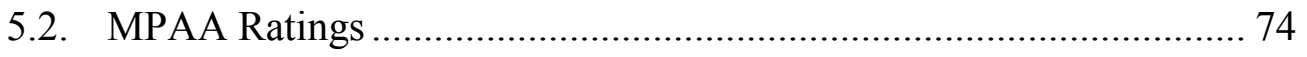

5.3. Provincial Agency Structures ...................................................... 76

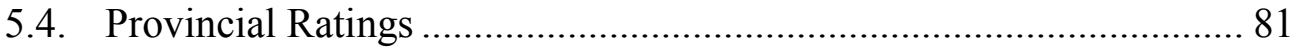




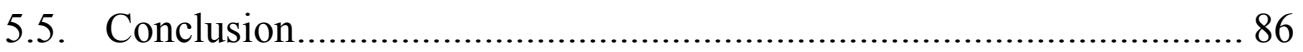

6. Comparing Classifications .................................................................. 92

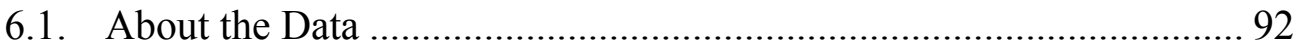

6.2. Discussion of English Language Agency Ratings ............................... 95

6.3. Comparison with Quebec Classifications ......................................... 100

6.4. Comparison with MPAA Classifications ……………………........... 102

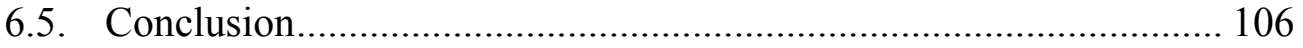

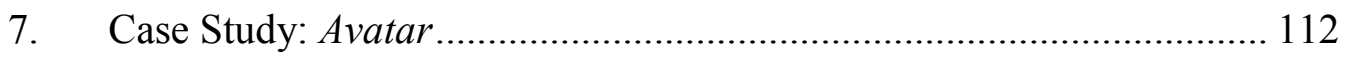

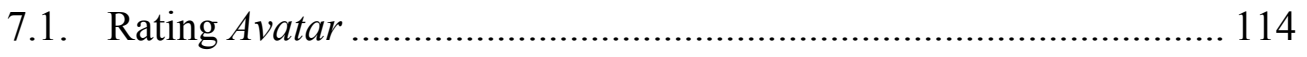

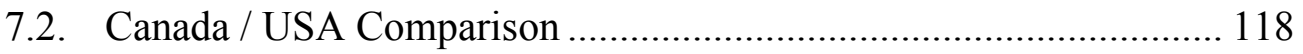

7.3. Encoding and Decoding Ratings ........................................................ 119

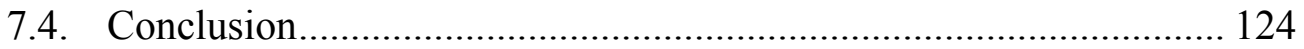

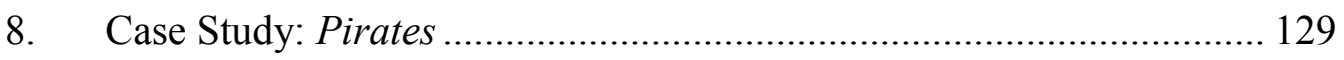

8.1. Rating Pirates in the United States ..................................................... 134

8.2. Rating Pirates in Canada................................................................ 135

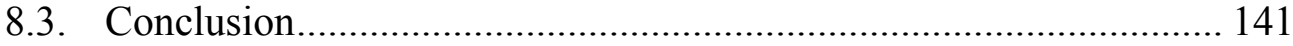

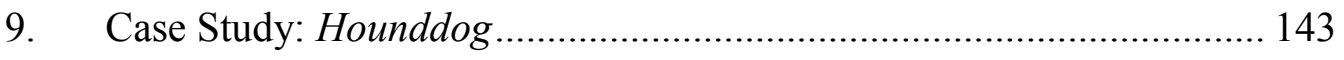

9.1. Hounddog and Independent Film Ratings in the USA...................... 146

9.2. Hounddog and Festival Film Ratings in Canada............................... 148

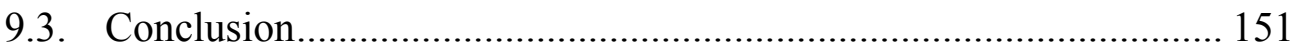


10. Conclusion.

Appendix A: Quebec Labels ............................................................................... 160

Appendix B: Ontario Guidelines Summary Handout .............................................. 161

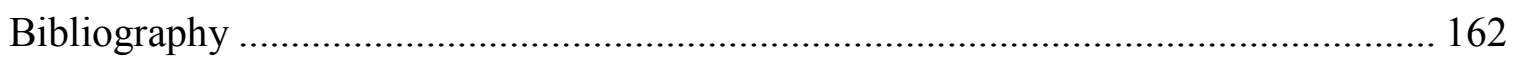




\section{List of Tables}

Table 1 - Agency Jurisdictions and Structures

Table 2 - Ratings Summary

Table 3 - Classifications for the Most Popular films of 2013

Table 4 - Avatar Classifications, Advisories, and other information 


\section{List of Figures}

Figure 1 - Pirates of the Caribbean DVD box cover

Figure 2 - Pirates (Restricted Version) DVD box cover

Figure 3 - Pirates (Uncut Version) DVD box cover 


\section{List of Appendices}

Appendix A - Avatar Classification Stickers in Quebec

Appendix B - Ontario Film Review Board Guidelines Handout 


\section{Introduction}

Film classification and censorship is frequently performed by governments, as in Canada, but in some countries, including the United States, the film industry does this. The rationale behind industry censorship and classification is that self-regulation is less restrictive and preferable to government regulation. Particularly in the United States, the notion of government regulation or censorship has long been associated with totalitarian regimes. In 1936, a writer addressing "the motion picture problem" noted "Censorship by the Government easily becomes an instrument of tyranny and cannot be tolerated in a Democracy." ${ }^{1}$ Decades later, the president of the American film industry's classification body claimed, "If you crush the current ratings system, strip it from (the) self-regulating hands of the industry itself, you will surely be confronting new ratings boards armed with the might of the law, governmentally constituted ratings boards politically populated by those who find what we create to be staining and soiling the values of the neighborhood."2

However, government regulation, at least in Canada, is less restrictive than industry self-regulation in the United States. For example, many films that are PG-13 in the United States are simply PG in Canada; many films that are PG in the United States are $\mathrm{G}$ in Canada. This suggests, counter-intuitively and opposite to the claims of the

\footnotetext{
${ }^{1}$ Sidney E. Goldstein, "The Motion Picture and Social Control," in The Movies on Trial: The Views and Opinions of Outstanding Personalities Anent Screen Entertainment Past and Present, ed. William J. Perlman (New York: MacMillan, 1936), 215.

${ }^{2}$ Jack Valenti, quoted in Michael Phillips, "Not Suitable in Dallas : Movies: Dentist Fred Aurbach Presides over the Only Big-City Film Ratings Board in the Country--a Thorn in Distributors' Sides," Los Angeles Times, accessed August 28, 2014, http://articles.latimes.com/1990-09-18/entertainment/ca817_1_classification-board.
} 
industry, that government ratings may be more liberal than industry ratings, and raises the question of how this occurs.

This thesis compares how film ratings are assigned in Canada and in the United States, and demonstrates that the Canadian government controlled mandatory ratings systems for films results in more liberal film ratings than the voluntary system in the United States. Through comparisons of the ratings agencies and systems in the provinces and in the United States, an analysis of one hundred recently classified films, and case studies, this thesis concludes that government controlled systems are more liberal due to public accountability, and that the greater scope of the Canadian ratings systems results in film classifiers ratings films in a broader context.

\subsection{American and Canadian Ratings Differences}

A simple explanation for the difference in ratings might be the assumption that Canada is a more liberal country than the United States. While Canada's politics are clearly more liberal on some issues, particularly in regard to personal sexual morality issues such as same sex marriage and birth control, they are more conservative on other issues, such as copyright exemptions for educational material. Political scientist Seymour Martin Lipset notes some literary analysts have argued that Canada's politics and history have led to a national literature which is more conservative. ${ }^{3}$ Jason Kaufman, in the same field, argues that "Canadians and Americans are so culturally similar that their separate

\footnotetext{
${ }^{3}$ Seymour Martin Lipset, Continental Divide: Values and Institutions of the United States and Canada (New York: Routledge, 1990), 52-53.
} 
nationality is virtually undetectable." ${ }^{4}$ While film ratings may be more liberal, it is difficult to argue they are an outcome of a more liberal culture when the degree and applicability of liberalism in that culture is uncertain.

The assumption that liberalism has led to less restrictive ratings also disregards the significantly different methods, scopes, and histories of the ratings systems. Canadian classifiers are government employees or appointees, with the public accountability and legislative authority that carries, while American classifiers are employees of a private organization. Classification is voluntary in the United States, while it is mandatory in most of Canada. Age restrictions are legally enforceable in Canada, but not in the United States. Home video does not require classification in the United States, but it is required in most of Canada. Sexually explicit films became legal in the United States decades before they became legal in Canada, and are not subject to classification. In Canada, once these films were legal, they became subject to classification in most jurisdictions. Canadian film classification has greater reach and authority than American classification, suggesting a more restrictive approach, yet despite, or perhaps because of that, the ratings themselves are more liberal.

\subsection{Rating Systems Background}

Governments around the world began creating film censorship agencies in the early 1900s, typically as part of regulations to set safety standards and licencing requirements for theatres, film exchanges or distributors, and projectionists. In Canada, these regulations came under provincial responsibility, and most were passed between

\footnotetext{
${ }^{4}$ Jason Andrew Kaufman, The Origins of Canadian and American Political Differences (Cambridge, Mass. : Harvard University Press, 2009), 3.
} 
1910 and $1914 .^{5}$ The constitutional validity of film censorship and ratings has been challenged in several provinces, before and after adoption of the Canadian Charter of Rights and Freedoms. Even when it has been found unconstitutional, film censorship and the operations of the agencies have not significantly changed.

There are now ratings agencies in six provinces: Nova Scotia, Quebec, Ontario, Manitoba, Alberta and British Columbia. The remaining jurisdictions either do not require film ratings, or rely on one or more of the other provincial agencies. All agencies classify feature films for theatrical exhibition, but requirements for film festivals and home video vary.

Censorship agencies in the United States originated at the municipal or state level, depending on which authority licenced theatres. A 1915 court case determined that films were not protected speech under the First Amendment, and could be legally censored. In an effort to avoid meeting the requirements of dozens of censorship agencies, major companies in the American film industry created the Production Code Administration, an agency to ensure films would be suitable for all audiences in any state.

Compliance was voluntary, and independent films and theatres continued to operate under the oversight of censor boards. However, a 1952 court case reversed the 1915 decision, and films became protected speech. This led to most state and municipal censors shutting down. In 1966, the Production Code Administration introduced ratings.

\footnotetext{
${ }^{5}$ Malcolm Dean, Censored! Only in Canada: The History of Film Censorship - The Scandal Off the Screen (Toronto: Virgo, 1981), 20.
} 
Chapters three and four provide more information on the historical development of ratings by the agencies, and chapter five outlines the current structures and operations of the agencies.

\subsection{Ratings Systems Relevance}

Since the late 1970s, when home video became widely available, the ability of any authority to censor, rate, or otherwise limit the distribution of material has been significantly weakened. Video tapes, DVDs, and particularly electronic files are easy to copy and distribute. It is relatively easy to obtain almost any film in an uncensored form, either online or by mail.

This availability of uncensored and unrated product has not reduced the awareness or prevalence of film ratings. They continue to be widely used, enforced, and even requested by distributors when not required. ${ }^{6}$ Private organizations offer complementary or competing ratings systems, testifying to public support for ratings. Agencies routinely receive complaints about being too strict and too lax from the public, and ratings decisions continue to be newsworthy, particularly for distributors seeking publicity. ${ }^{7}$

Ratings still affect content. For example, Ontario initially gave a Restricted rating to The Texas Chainsaw Massacre (Marcus Nispel, 2003), not allowing admission to anyone under eighteen. The distributor discussed the rating with the Board, and removed

\footnotetext{
${ }^{6}$ Several agencies do not require classification of home video content that has been previously broadcast over the air and unscrambled. Despite this, distributors routinely submit DVDs of old television shows for classification, so that they can be sold with ratings.

${ }^{7}$ Multiple sources reported that eOne films appealed Nova Scotia's 18A classification for Riddick (David Twohy, 2013). The rating, the same as given in four other provinces, was upheld.
} 
one shot. ${ }^{8}$ This allowed the film to be rated 18A. Ratings also affect pre-production and production decisions.

As Clarissa Smith notes in her study of British soft-core magazines, "regulation is not simply a repressive tool ... it also forms a set of production imperatives with significant effects on the content...." Elements such as language or sexuality may be added or toned down to reach the target market. A film intended for a young teen audience may have gratuitous swearing added to avoid the stigma of a $\mathrm{G}$ rating. ${ }^{10} \mathrm{~A}$ studio contract typically specifies the desired rating for the film, and production notes may refer to the desired rating. The published script for Michael Crichton's Westworld (1973) includes set notes such as "preliminary hanky-panky consonant with a PG rating is taking place."11

In the United States, classification is performed by the Classification and Rating Administration (CARA), part of the Motion Picture Association of America (MPAA). MPAA members include the six largest American film companies. ${ }^{12}$ The companies that finance and thus control production are also the ones that regulate content. Multiple

\footnotetext{
${ }^{8}$ Personal communication with a member of the Board, September, 2005.

${ }^{9}$ Clarissa Smith, "A Perfectly British Business: Stagnation, Continuities, and Change on the Top Shelf," in International Exposure: Perspectives on Modern European Pornography, 1800-2000, ed. Lisa Z. Sigel (Piscataway NJ: Rutgers University Press, 2005), 156.

${ }^{10}$ Tom Perlmutter, "Going Public: Mary Brown and the Ontario Film Review Board," Cinema Canada, no. 117 (April 1985): 7.

${ }^{11}$ Michael Crichton, Westworld (Bantam, 1974), 28.

${ }^{12}$ Walt Disney Studios Motion Pictures; Paramount Pictures Corporation; Sony Pictures Entertainment Inc.; Twentieth Century Fox Film Corporation; Universal City Studios LLC; and Warner Bros.

Entertainment Inc. "Meet the MPAA," Motion Picture Association of America, accessed January 23, 2015, http://www.mpaa.org/our-story/.
} 
submissions to review content, beginning with script reviews, are common. ${ }^{13}$ Films outside of the Hollywood system are also affected by regulations. As Eric Schaefer notes in "Bold! Daring! Shocking! True!": A History of Exploitation Films, the content of classic exploitation films consisted of what Hollywood did not offer, and Hollywood relied on these films to provide a contrast to its own wholesome product. ${ }^{14}$ It is now a common marketing practice for crude adult comedies, and other films with sexual or violent content, to release an unrated DVD version, providing additional content "not seen in theatres." 15

Regulations intended to restrict films can even have the opposite effect. Section 2257 of the United States Code of Federal Regulations, the "Child Protection and Obscenity Enforcement Act" was signed into law by President Ronald Reagan in 1988. It was probably not the intention of the law's conservative supporters to help pornography production, but that was a result. The law's defined proof of legal age record keeping requirements for performers in adult sex films has been adopted by pornography producers worldwide, for films and online content. This requirement has essentially defined legal content and stabilized the industry despite variations in national laws. ${ }^{16}$

\footnotetext{
${ }^{13}$ Stephen Tropiano, Obscene, Indecent, Immoral \& Offensive: 100+ Years of Censored, Banned, and Controversial Films (New York: Limelight Editions, 2009), 96. Tropiano references a 1972 source, but more recent sources suggest script review is still part of the process, and a member of the MPAA has noted there can be up to a dozen resubmissions to obtain the desired rating (Personal communication, June 2014).

${ }^{14}$ Eric Schaefer, Bold! Daring! Shocking! True: A History of Exploitation Films, 1919-1959 (Durham: Duke University Press Books, 1999), 4-14.

15 Though unrated by the MPAA, unrated versions sold in Canada have been rated by the appropriate agency.

${ }^{16}$ Katalin Szoverfy Milter and Joseph W. Slade, "Global Traffic in Pornography: The Hungarian Example," in International Exposure: Perspectives on Modern European Pornography, 1800-2000, ed. Lisa Z. Sigel (Piscataway NJ: Rutgers University Press, 2005), 174-75.
} 
Ratings may someday play a role in shaping internet content. The internet has, so far, been resistant to centralized authority and ratings. This is not for lack of effort. Schemes to rate web page content have been tried and failed. ${ }^{17}$ The British government is requiring major broadband internet service providers to offer filtering, so that subscribers must opt in to receive pornography. Several non-democratic countries restrict internet content, and various software products are available to limit internet access in libraries, schools, and private homes. Both filters and state blocking are routinely shown to be both too restrictive and easily circumvented.

The internet is similar to the early film industry. Much of the visual content is aesthetically or technically crude, copyright is widely violated, distribution and consumption is decentralized, and many hands are wrung over content and its effects. As the film industry centralized and became subject to censorship and ratings, it is conceivable that the internet will also become subject to content regulations.

James Boyle suggests that the internet may be easier to censor than many claim, partly through developments in filtering technologies and partly because censoring technologies tend to become invisible and normalized. ${ }^{18}$ Such censorship as is currently practiced online is performed at larger sites through a mix of policy and crowd sourcing, but there are problems with this approach. ${ }^{19}$ The question is not whether the internet has

\footnotetext{
17 The Recreational Software Advisory Council Internet ratings system (RSACi) was formed in 1995 and closed in 1999. The Internet Content Rating Association (ICRA) system started in 1994, and ceased operations in 2010. One of the participants has written about why ICRA failed: Archer, Phil. ICRAfail: A Lesson For the Future 2009. Accessed September 18, 2014 http://philarcher.org/icra/ICRAfail.pdf

18 "Foucault in Cyberspace: Surveillance, Sovereignty, and Hardwired Censors," University of Cincinnati Law Review 66 (January 1, 1997): 177-205.

${ }^{19}$ Policies tend to focus on issues related to copyright and intellectual property, rather than issues like individual harassment. Crowd sourcing is vulnerable to internet mobs that have repeatedly demonstrated
} 
or will have censorship, but whether the censorship, at least in democracies, will continue to be done by industry, crowdsourcing, or by governments. As with the film industry, proponents of an unfettered internet consider government censorship the worst possible option. ${ }^{20}$ A comparison of industry censorship and censorship by a democratic government is beneficial to seeing if this concern is justified.

Finally, comparing the government ratings systems in Canada with each other and with the United States provides information about the provinces and the country. To paraphrase Lipset, "Nations and provinces can be understood only in comparative perspective." 21

The operations of film review agencies is a small part of Canadian state power, but the application of this power both shapes and reflects Canadian culture. All of the agencies have to the legal right to limit children's viewing of certain films, and most of the agencies have the legal right to ban a film, as well as the power of prior restraint. However, as public facing agencies, all of the boards have some degree of public participation, and like any government agency, their operations are ultimately under the control of elected officials.

extreme misogyny. For example, see "The Unsafety Net: How Social Media Turned Against Women," The Atlantic, October 2014, http://www.theatlantic.com/technology/archive/2014/10/the-unsafety-net-howsocial-media-turned-against-women/381261/?single_page=true Accessed Dec 29, 2014.

${ }^{20}$ For example, see papers by White, Bell, and Brand and Finn. Amy E. White, Virtually Obscene: The Case for an Uncensored Internet (Jefferson, N.C: McFarland \& Company, 2006).; Tom W. Bell, Internet Privacy and Self-Regulation: Lessons from the Porn Wars (Cato Institute, August 9, 2001), http://gateway.proquest.com.proxy.library.carleton.ca/openurl?url_ver=Z39.88-

2004\&res_dat=xri:policyfile\&rft_dat=xri:policyfile:article:00042670. J. Brand and M. Finn, "Informing Our Own Choices: A Proposal for User-Generated Classification," Media International Australia, no. 130 (February 2009): 112-26.

${ }^{21}$ Continental Divide, xiii. 
The research and conclusions here should be considered a first step towards a deeper analysis of the relationships between cultural regulations and cultural content. A more nuanced examination would include analysis of film aspects such as genre and ratings content elements (sexuality, violence, etc.), to determine if agencies approach these differently, why they might, and the cultural meanings of that.

\subsection{Literature Review}

There does not appear to be any academic work specifically comparing film ratings between countries, or between provinces in Canada. There are a few commissioned reports for ratings agencies, and one study tested its conclusions on the operations of the MPAA by comparing a group of film ratings in four countries, including Canada and the United States.

There is also very little work about the operation of film classification in Canada, and most of it is dated. However, there is a substantial body of literature on film censorship and classification in the United States. Literature on obscenity and pornography is also relevant, as this addresses the upper limits of what is permissible in films, and while much of this literature is American, there is some Canadian and international material.

A full discussion of the literature relevant to this thesis is presented in chapter two. This thesis will help bring the literature on Canadian film classification up to date, and provide information about current approaches to film rating in Canada. 


\subsection{Theoretical Context}

Films, the ratings and warning messages that accompany them, and the public activities associated with censorship/review agencies, will be considered as cultural texts with multiple possible meanings following the model of Stuart Hall's theory of encoding and decoding. ${ }^{22}$

This paper does not take a stand on censorship, not out of an academic evasion of responsibility, nor out of the resignation that Michael Holquist expresses. He states "to be for or against censorship as such is to assume a freedom no one has. Censorship is. One can only discriminate among its more and less repressive effects." ${ }^{23}$ This acknowledges that being for or against censorship is pointless, but unfortunately still characterizes censorship as a bad thing. A more neutral position concerning research of potentially controversial issues is expressed by Lisa Sigel: "Academics engage the world of pornography to fulfill a basic function of scholarship: to provide a reservoir of information on a topic." 24 This thesis aims to provide a reservoir of information about film censorship. This does not preclude criticism of the ratings process.

\subsection{Methodology}

Chapters three and four provide historical context for film classification in the United States and Canada. The fifth chapter describes the current structures of the

\footnotetext{
22 Stuart Hall, "Encoding/Decoding," in Culture, Media, Language: Working Papers in Cultural Studies 1972-79 (London: Routledge, 1991), 117-27.

${ }^{23}$ Michael Holquist, "Introduction: Corrupt Originals: The Paradox of Censorship," PMLA 109, no. 1 (January 1, 1994): 16.

${ }^{24}$ Lisa Z. Sigel, "Introduction: Issues and Problems in the History of Pornography," in International Exposure: Perspectives on Modern European Pornography, 1800-2000, ed. Lisa Z. Sigel (Piscataway NJ: Rutgers University Press, 2005), 1.
} 
agencies and the classification schemes. Chapter six reviews the Canadian and American ratings assigned to the top one hundred North American feature films released in 2013. As discussed in that chapter, comparing ratings between different ratings systems is difficult. Rather than make subjective judgements to determine numbers for statistical analysis, this analysis discusses the ratings differences in a more qualitative manner. Chapters seven, eight and nine are case studies of three films: A mainstream release, Avatar (James Cameron, 2009), an adult sex film, Pirates (Joone, 2005), and a festival film, Hounddog, (Deborah Kampmeier, 2007). The three types reflect the three general approaches used in Canada. The agencies that review both mainstream films and adult sex films treat them differently, charging different fees and following different guidelines. Festival films have varying degrees of exemption from the regular classification process. The three approaches are also applicable to films in the United States. Mainstream films are classified by the MPAA, festival films might be, but not necessarily treated the same, and adult sex films are not classified.

In each case, the film chosen is intended to be representative of that type of film, and not necessarily significant with regard to classification. Notwithstanding that, all three films have had some degree of controversy with their ratings. In addition, all three films are recent enough to have been rated under current systems and laws. Avatar was chosen to represent mainstream films as it is currently the highest grossing mainstream film. Pirates remains a popular adult film several years after release, and, unusually for an adult film, an edited version was released and classified by the MPAA. Hounddog was an unrated festival release, later released theatrically with an MPAA classification, and then released on DVD, with classifications in Canada. 


\subsection{Parameters}

Several American organizations classify films. Histories of the Production Code typically refer to the involvement of the Catholic Church at the outset, implying the church lost interest in films once the Production Code was in place. In fact that church has long issued its own film ratings and continues to do so. The Catholic News Service now provides the film ratings once supplied by the Office for Film and Broadcasting of the U.S. Conference of Catholic Bishops. Theatrical releases are rated for "artistic merit and moral suitability" and online reviews are available for films dating back to the 1930 s. $^{25}$

Since 1991, the American Dove Foundation has reviewed and rated films for their "family suitability" and alignment with "traditional Judeo-Christian values." Some studios include the "Dove Approved" logo on the DVD packaging for films which have been blessed with Dove's approval. ${ }^{26}$ There are websites that offer reviews based on various child or family standards, including Christian Spotlight on Entertainment, KidsIn-Mind ("Movie Ratings That Actually Work"), Screenit ("Movie Reviews for Parents"), and Movie Mom ("A parents' eye on media, culture, and values"). ${ }^{27}$

Starting in the late 1990s, a number of small American companies prepared and sold "family friendly" edits of feature films for home video. The concept was similar to

\footnotetext{
25 "Movie Reviews," Catholic News Service, accessed January 9, 2015, http://www.catholicnews.com/movies.htm.

26 "About Dove: How a Few Parents Launched a Movement," http://www.dove.org/the-story-of-the-dovefoundation/ Accessed December 29, 2014

27 "Christian Spotlight on Entertainment," Films for Christ / Christian Answers Net, accessed January 9 , 2015, http://christiananswers.net/spotlight/. "Kids-In-Mind," Critics / Kids-In-Mind, accessed January 9, 2015, http://www.kids-in-mind.com/. "Screenit," accessed January 9, 2015, http://www.screenit.com/. "Movie Mom," Belief Net - Movie Mom, accessed January 9, 2015, http://www.beliefnet.com/columnists/moviemom.
} 
the edited versions of films prepared for television broadcast or in-flight viewing, but those edits are prepared with the cooperation of the studios. ${ }^{28}$ Courts eventually determined that the companies selling "family friendly" versions of films were violating copyrights. ${ }^{29}$

A legal alternative for people wanting "family friendly" movies is offered by ClearPlay. ClearPlay uses a modified DVD player and online data to censor DVD playback on the fly, as per user settings. Filter data is available for most popular films. Censored streaming movies are also available through the ClearPlay website. ${ }^{30}$ With ClearPlay, a viewer will never know what they are missing - the invisible technological censorship predicted by Boyle.

The MPAA ratings are the dominant system, the only one used by theatres, and the only one that consistently works with Hollywood producers during production of films. The existence of the other agencies reveals dissatisfactions with the MPAA ratings, and they are worth exploring in future research, but they are outside the scope of this paper.

Within Canada, although ratings are applied by government agencies, approval does not mean a film is legal under the criminal code. The ratings agencies are provincial, while criminal obscenity is a federal concern. Approved films can and have been seized

\footnotetext{
${ }^{28}$ Rick Lyman, "Hollywood Balks at High-Tech Sanitizers; Some Video Customers Want Tamer Films, and Entrepreneurs Rush to Comply," The New York Times, September 19, 2002, sec. Movies, http://www.nytimes.com/2002/09/19/movies/hollywood-balks-high-tech-sanitizers-some-video-customerswant-tamer-films.html.

${ }^{29}$ Ameilia Nielson-Stowell, "CleanFlicks Plans to Appeal Ruling," DeseretNews.com, July 9, 2006, http://www.deseretnews.com/article/640193492/CleanFlicks-plans-to-appeal-ruling.html?pg=all.

30 "ClearPlay Movies," ClearPlay, accessed January 9, 2015, http://www.clearplay.com.
} 
by the police as obscene materials. In addition, a previously approved film may be refused entry into the country at the discretion of Canada Customs. Agencies that review and ban adult sex films use criminal obscenity as a guideline, so federal law is a factor in ratings, but the actions of police and customs are outside the scope of this paper.

Despite the wider scope of Canadian ratings agencies compared to the MPAA, every agency allows some material to be distributed without ratings. Examples include business training videos, non-profit religious films, promotional videos, recorded sports events, video material integrated into concerts and theatrical performances, and exercise videos. Exemption from classification is generally only applicable to films that would most likely receive a $\mathrm{G}$ rating if classified, and they are not classified in the United States, so exclusion of these films has no bearing on this research.

Several Canadian jurisdictions require video games to be rated, but none rate games. Instead, they require games to have an ESRB (Entertainment Software Rating Board) rating. This is applied by the industry, but there are policies in place that give the Boards some input into the ESRB. ${ }^{31}$ This is a minor function of the Boards, and outside the scope of this paper.

The Motion Picture Association of Canada (MPA-Canada) maintains the Canadian Home Video Rating System (CHRVS), which issues Canadian rating information for DVDs sold in Canada. The ratings are based on the provincial ratings, and the operation of the CHRVS will be discussed in chapter five. MPA-Canada does not perform any classification.

\footnotetext{
${ }^{31}$ All of the provincial agencies except Quebec are members of the Interprovincial Film Classification Council of Canada, founded in 2003. Quebec has observer status. The Council participates in the Canadian Advisory Committee of the ESRB.
} 


\subsection{Notes on Terms}

Censorship studies considers censorship to be much broader than regulations affecting production and distribution. Film content and distribution are also affected by pressure groups on the left and right of the political spectrum and by commercial interests, and production is subject to specific contractual and funding considerations as well as broader issues of power and culture. This paper focuses on censorship in the narrow sense of regulations.

Several agencies claim they no longer censor, just rate or classify, but distributors can and do cut films to obtain desired ratings, and avoid bans, which are still permitted in most jurisdictions. For example, the web site for the Régie du cinéma du Quebec notes: "Censorship in Québec was officially abolished in 1967 with the creation of the Bureau de surveillance du cinéma. Should the Régie du cinéma feel that a film interferes with public order, it can refuse to classify it, which would mean that the film could not be distributed in Québec."32 The term and concepts of censorship are still applicable when discussing systems that claim to only classify.

Some agencies refer to reviewing films as rating, while others call this classifying, and the decision might be a rating or a classification. The terms are interchangeable in this paper. Several provinces refer to their ratings organization as a board, while others eschew the term. The term agency is used to refer to any ratings organization.

The literature on censorship and classification typically uses the terms liberal and liberalization to refer to ratings that are lower, allowing younger viewers, or to less censorship. The terms conservative or restrictive are typically used to refer to ratings that

\footnotetext{
32 Government of Quebec, "Régie Du Cinéma," accessed January 19, 2015, http://www.rcq.gouv.qc.ca/.
} 
are higher, or more censorship. The use of these terms has been contested. For example, Richard Ellis argues that increased acceptance of sexuality in films represents a politicization of the content, rather than liberalized moral standards. ${ }^{33}$ The use of these terms in Canada is further complicated by possible association with the major political parties, the Liberals and the Conservatives. Acknowledging that these are contested terms, this thesis nevertheless uses liberal and conservative or restrictive to describe and compare censorship and classification approaches, as in typical in the literature.

Although MPAA ratings are actually issued by CARA, they are generally known as the MPAA ratings, and that is term used here, unless referring specifically to CARA.

\footnotetext{
${ }^{33}$ Quoted in Linda Williams, Hard Core: Power, Pleasure, and the "Frenzy of the Visible," Expanded
} edition (Berkeley: University of California Press, 1999), 89. 


\section{Literature Review}

\subsection{International Film Ratings Comparisons}

The most relevant and thorough research is Comparing Classifications: Feature films and Video Games 2012 \& 2013, prepared for the Office of Film and Literature Classification in New Zealand, by Henry Talbot. It compares the ratings for about a hundred films between New Zealand and the Australian Classification Board, the Ontario Film Review Board, the Singapore Media Development Authority, the British Board of Film Classification, and the MPAA. Ontario was found to have one of the most liberal systems. Though just one province, this supports the conclusion that Canada's ratings are more liberal than in the United States. The report offers very little explanation for the differences found. The data will be discussed further in chapter six, in the analysis of ratings. An earlier version of this report was issued for 2010 and 2011, by Kate Ward and Talbot. $^{34}$

Jeffrey Brand, a Professor of Communication and Media at Bond University in Australia, prepared a report for the Australian Parliament in 2002, which summarizes the rating systems of twenty-two countries. "A Comparative Analysis of Ratings, Classification and Censorship in Selected Countries around the World" covers some of the issues in making international comparisons between ratings agencies. Although useful in presenting the different options in different countries, it does not compare the end results of the systems, and there is little discussion of the reasons for differences. Brand

\footnotetext{
${ }^{34}$ Kate Ward and Henry Talbot, Comparing Classifications: Feature Films and Video Games 2010 \& 2011 (Wellington, New Zealand: Information Unit at the Office of Film and Literature Classification, 2013), www.censorship.govt.nz.; Henry Talbot, Comparing Classifications: Feature Films and Video Games 2012 \& 2013 (Wellington, New Zealand: Information Unit at the Office of Film and Literature Classification, 2014), www.censorship.govt.nz.
} 
notes that a key difference between systems is whether they are run by government or industry, and draws attention to the less common use of guidelines by industry based agencies. He speculates that the closer relationship between the industry and industry run agencies makes guidelines less necessary, but does not fully explore the implications. The use of guidelines varies within Canada, and the relationship between the industry and ratings is relevant to discussion of the MPAA, particularly with regard to festival films. Canada is noted as being unique among the countries examined for its use of a provincial rather than national system, and only Alberta is considered in his report. There is no explanation for that choice. ${ }^{35}$

"The Ratings Game: Asymmetry in Classification," by David M. Waguespack and Olav Sorenson, from 2011, is one of several papers criticizing the operations of the MPAA. This detailed statistical analysis of MPAA ratings used a large group of films and considered factors such as studio, crew, cast and director history. It concluded that films from major studios received less restrictive ratings than films from independent studios. They then compared ratings between the MPAA and Ontario, Australia, and UK, and concluded the pattern of powerful studios obtaining less restrictive ratings was repeated in the industry operated British Board of Film Classification, while the publicly accountable government boards in Australia and Ontario demonstrated no such bias. In their analysis, the government agencies are more restrictive than the MPAA. This is not consistent with the New Zealand work or this research, however it is possible for the government boards to be more restrictive on some films and less restrictive

\footnotetext{
35 Jeffrey Brand, A Comparative Analysis of Ratings, Classification and Censorship in Selected Countries around the World (Australia: Centre for New Media Research and Education, Bond University., 2002), http://epublications.bond.edu.au/cgi/viewcontent.cgi?article=1886\&context=hss_pubs.
} 
overall. Waguespack and Sorenson called for more study of the classification process to determine if ratings bias is systemic or isolated. " 36 The possible MPAA bias against independent films is discussed in chapter nine, the case study of a festival film.

Bret Boyce's "Obscenity and Community Standards" law journal paper from 2008 is concerned with obscenity, not ratings per se, but the literature on obscenity is relevant to ratings. Boyce stresses the value of making comparisons between Canada and the United States, due to their similar origins but different evolutions of obscenity law. ${ }^{37}$

With the limited literature available there is a consensus that international comparisons are appropriate and beneficial. The goals of literature comparing film ratings systems vary, and none of the comparative literature appears to look into the relationship between how film ratings agencies operate and the resulting ratings.

\subsection{Ratings in the USA}

There is a lot of material about the operation of the MPAA ratings system and film censorship in the United States. Every history of the American film industry devotes some space to discussion of the Production Code. It has been a subject of study since the 1936 essay collection: The Movies on Trial: The Views and Opinions of Outstanding Personalities Anent Screen Entertainment Past and Present. That book, referring to the implementation of the Code, notes: "Now that public indignation against the movies has

\footnotetext{
${ }^{36}$ David M. Waguespack and Olav Sorenson, "The Ratings Game: Asymmetry in Classification," Organization Science 22, no. 3 (June 1, 2011): 550, doi:10.1287/orsc.1100.0533.

${ }^{37}$ Bret Boyce, Obscenity and Community Standards, SSRN Scholarly Paper (Rochester, NY: Social Science Research Network, June 1, 2008), 302-303, http://papers.ssrn.com/abstract=1418684.
} 
subsided, an attempt has been made to present, between the covers of this volume, the issues involved in the recent controversy." 38

The issues are still being presented and re-examined. A 2006 essay collection, Movie Censorship and American Culture, covers the latest developments, reaches back to censorship in the late 1800 s, and expands the notion of censorship to pressure groups and other non-regulatory agencies. As contributor Garth Jowett notes in his essay, despite the American First Amendment guaranteeing free speech, movies were subject to prior restraint from 1915 to $1952 .{ }^{39}$ That restriction is an anomaly in the march of freedom, and a source of the fear that government censorship may return. The essay "Hollywood, Main Street, and the Church: Trying to Censor the Movies before the Production Code" from contributor (and editor) Francis G. Couvares provides some early censorship history. $^{40}$

Stephen Tropiano's Obscene, Indecent, Immoral, and Offensive: 100+ Years of Censored, Banned, and Controversial Films, from 2009, provides a thorough history of film regulation in the United States, including copies of the various guidelines and codes, past and present. The bulk of this work is case studies of controversial films, however the

${ }^{38}$ William J. Perlman, "Why This Book?," in The Movies on Trial: The Views and Opinions of Outstanding Personalities Anent Screen Entertainment Past and Present, ed. William J. Perlman (New York: MacMillan, 1936), vii.

39 "'A Significant Medium for the Communication of Ideas:' The Miracle Decision and the Decline of Motion Picture Censorship, 1952-1968.," in Movie Censorship and American Culture, ed. Francis G. Couvares, second edition (Amherst: University of Massachusetts Press, 2006), 258.

40 "Hollywood, Main Street, and the Church: Trying to Censor the Movies before the Production Code," in Movie Censorship and American Culture, ed. Francis G. Couvares, second edition (Amherst: University of Massachusetts Press, 2006), 129-58. 
chapters on the origins of film censorship and the development of the MPAA rating system are a rich source of information. ${ }^{41}$

Raymond J Haberski Jr.'s 2007 Freedom to Offend: How New York Remade Movie Culture takes a different and suspiciously elitist approach to the history of controversial films, stating that artistic taste, now lacking, not the courts or censors, should limit films. This work also suggests there was a tension between the west coast origins of Hollywood films, and the east coast censorship battles in New York. This is an interesting contribution to the history of film censorship in the United States, but not sufficiently relevant to this comparison of ratings systems. ${ }^{42}$

Just as there is much reconsideration and discussion of past censorship, the current operations of the MPAA are widely and frequently criticized. As noted above, "The Ratings Game: Asymmetry in Classification" found the system favours the major studios with less restrictive ratings. Kirby Dick's 2006 documentary, This Film is Not Yet Rated, reached the same conclusions. Dick also found the ratings system to be very secretive, and in some cases rated similar sexual activity higher for same sex couples than for opposite sex couples. Although Dick's examples are selective, and focus is primarily on the Restricted / NC-17 boundary, the film does provide some information on the current operations of the MPAA. ${ }^{43}$

Other criticisms of the MPAA ratings system, though valid, have limited relevance to Canada-USA comparisons. A 1990 study, "Applying Social Science

${ }^{41}$ Tropiano, Obscene, Indecent, Immoral \& Offensive.

${ }^{42}$ Haberski, Jr. Raymond J., Freedom to Offend: How New York Remade Movie Culture (Lexington: The University Press of Kentucky, 2007).

${ }^{43}$ Kirby Dick, This Film Is Not Yet Rated, 2006. 
Research to Film Ratings: A Shift from Offensiveness to Harmful Effects" finds the system is misguided. The researchers propose a more complex rating system, based on what is known to be harmful to children, rather than what might be offensive to parents. ${ }^{44}$ Though dated, the ratings systems have not changed since then, and the criticism is still valid. The specifics of the paper are not relevant to this comparison, but the general concerns are applicable to discussions of ratings.

A 2001 study, "A Validity Test of Movie, Television, and Video-Game Ratings" also concludes more science is needed in determining appropriate ratings.

Recommendations include a single system for all media (films, television, and video games), rather than the current separate systems, and, unusually, a recommendation for that system to be mandatory, though the authors do not go as far as suggesting it be government operated. ${ }^{45}$ Again, the specific research is not relevant, and Canada already has mandatory ratings. Consistent ratings through all media has advantages, but would be difficult to implement. Quebec already uses similar ratings systems for films and television, but cannot fully integrate the two systems. Despite occasional attempts, and some sharing agreements, Canada does not have a national single system for films, let alone all media, for reasons that will be noted in chapter three.

Kimberly M. Thompson and Fumie Yokota compared the age based MPAA ratings with content based ratings from Kids-In-Mind, in 2004. Their study, "Violence, Sex, and Profanity in Films: Correlation of Movie Ratings With Content," found the

\footnotetext{
${ }^{44}$ Barbara J. Wilson, Daniel Linz, and Barbara Randall, "Applying Social Science Research to Film Ratings: A Shift from Offensiveness to Harmful Effects," Journal of Broadcasting \& Electronic Media 34, no. 4 (September 1, 1990): 443-68, doi:10.1080/08838159009386754.

${ }^{45}$ David A. Walsh and Douglas A. Gentile, "A Validity Test of Movie, Television, and Video-Game Ratings," Pediatrics 107, no. 6 (June 1, 2001): 1302-8, doi:10.1542/peds.107.6.1302.
} 
MPAA system less informative. They also noted that over the eleven year span of ratings analyzed, there was clear evidence of ratings creep. ${ }^{46}$ This is the tendency to allow more extreme material in the same classification over time. Additional studies, "21st Century Ratings Creep: PG-13 and R" (2006), and "MPAA Ratings Creep," (2011) from Ron Leone and Nicole Houle, and Ron Leone and Laurie Barowski, respectively, also found evidence of ratings creep. ${ }^{47}$

Ratings creep suggests the MPAA ratings are becoming more liberal, though not necessarily relative to Canada's ratings, which may also be subject to ratings creep. A possible future project would be to replicate these studies with Canadian ratings. Though ratings creep is typically presented as a problem with classification systems, it may also reflect changing social concerns. The weighting of elements in these studies should be taken into consideration. For example, Thompson and Yokota note that "G-rated animated films depict significantly more violence than non-animated G-rated films."18 Most agencies consider animated violence as less harmful than more realistic nonanimated violence.

Despite the many concerns about the MPAA ratings, there is generally no consideration of approaches in other countries. Critics either call for no regulation, or improvements to the existing industry run system. The paper "Motion Picture Ratings in the United States" notes that although CARA "is not perfect - what is? - it is far

\footnotetext{
${ }^{46}$ Kimberly M Thompson and Fumie Yokota, "Violence, Sex, and Profanity in Films: Correlation of Movie Ratings With Content," Medscape General Medicine 6, no. 3 (July 12, 2004), http://www.ncbi.nlm.nih.gov/pmc/articles/PMC1435631/.

${ }^{47}$ Ron Leone and Nicole Houle, "21st Century Ratings Creep: PG-13 and R" 23, no. 1 (June 1, 2006): 53 61.; Ron Leone and Laurie Barowski, "MPAA Ratings Creep" 5, no. 1 (February 1, 2011): 53-68.

${ }^{48}$ Thompson and Yokota, "Violence, Sex, and Profanity in Films," 6.
} 
preferable to the alternatives", i.e. government censorship. ${ }^{49}$ Although the author, a chairman of CARA, has an obvious bias in favour of CARA, and this 1997 law journal article is essentially praise for CARA, the fear of government regulation is the same as that expressed by critics of CARA.

\subsection{Adult Sex Films in the USA}

In the United States, adult sex films are not subject to any ratings body, though they are subject to obscenity laws. Those laws are also the upper limit of what might be allowed in an NC-17 film. Sexuality is the most emotionally charged and frequent source of ratings conflicts in Canada and the United States. Therefore literature on pornography and obscenity must be considered.

Much of the literature on pornography considers adult sex films with other forms of pornography such as magazines and books, and in isolation from the film industry. These works generally divide into two camps: For and Against. For example, Nadine Strossen's Defending Pornography: Free Speech, Sex, and the Fight for Women's Rights (1995), claims opposition to pornography is repressive for women, while Pornography: The Production and Consumption of Inequality (Gail Dines, Bob Jensen, Ann Russo, 1997), claims pornography is repressive for women. ${ }^{50}$ Both camps have valid concerns, but neither tends to address the regulated status quo for films, beyond being dissatisfied with it for different reasons.

\footnotetext{
${ }^{49}$ Richard M. Mosk, "Motion Picture Ratings in the United States," Cardozo Arts \& Entertainment Law Journal 15, no. 1 (1997): 135.

${ }^{50}$ Nadine Strossen, Defending Pornography: Free Speech, Sex, and the Fight for Women's Rights (New York: Scribner, 1995).; Gail Dines, Bob Jensen, and Ann Russo, Pornography: The Production and Consumption of Inequality (New York: Routledge, 1997).
} 
There are widely reported concerns about pornography as a legitimizer of sexual violence, but there is evidence this concern is misdirected. The 1990 study "Movie Ratings and the Content of Adult Videos: The Sex-Violence Ratio" compared the content of R-rated films and adult sex films, and found there was more sexual violence in R-rated films. ${ }^{51}$ Although it is possible there is now more sexual violence in recent pornography, given the evidence of ratings creep noted above, there may be also be more sexual violence in R-rated films. More recent data would be valuable, but concerns about the increasing sexual violence (and availability) of sexually explicit materials have been expressed since the 1960s, and are based more on myth than fact. ${ }^{52}$

Some works that discuss pornography in the context of the film industry use a definition of pornography that is so broad as to be meaningless. The first essay in the 2007 collection Pop-Porn: Pornography in American Culture defines pornography as "overt sexuality." 53 Focus on the Family's Protecting Your Child In an X-rated World opens its discussion on the pervasiveness of film pornography with the scenes of nudity and implied sexual activity in the PG-13 rated Titanic (James Cameron, 1997). ${ }^{54}$ As might be suspected, the authors find the MPAA ratings system ineffective.

\footnotetext{
${ }^{51}$ Ni Yang and Daniel Linz, "Movie Ratings and the Content of Adult Videos: The Sex-Violence Ratio," Journal of Communication 40, no. 2 (January 1990): 28-42.

${ }^{52}$ For example, the 1986 Meese Commission report concluded sexual violence in pornography was increasing, but the researchers cited claimed their data was misinterpreted, and that sexual violence in pornography had been decreasing for the past ten years. Linda Williams, Hard Core: Power, Pleasure, and the "Frenzy of the Visible", Expanded Edition, Reprint edition (Berkeley: University of California Press, 1999), $186-187$.

${ }^{53}$ Ann C. Hall and Mardia J. Bishop, eds., Pop-Porn: Pornography in American Culture (Westport, Conn: Praeger, 2007).

${ }^{54}$ Frank York and Jan LaRue, Protecting Your Child in an X-Rated World, Focus on the Family (Wheaton, Ill: Tyndale, 2002).
} 
Linda Williams' Hard Core: Power, Pleasure, and the "Frenzy of the Visible," published in 1989 and expanded in 1999, is a significant text in its consideration of sex films as films, while not being insensitive to social concerns. Consistent with the "SexViolence Ratio" study noted above, Williams concludes that persons concerned about displays of sexual power in film are pre-occupied with the appearance of the penis, when the real threat is the phallus. ${ }^{55}$ Williams provides significant information on the history of adult sex films and obscenity concerns, which will be considered in chapters four and eight. Williams' Screening Sex, from 2008, considers sexuality primarily in mainstream films, but acknowledges the influence of adult sex films. ${ }^{56}$

Williams edited the essay collection Porn Studies (2004), which includes Eric Schaefer's "Gauging a Revolution: 16mm Film and the Rise of the Pornographic Feature." ${ }^{57}$ This essay challenges the conventional history of the development of the narrative feature adult sex film by providing details about the production, distribution and exhibition of these films during the 1960s and 1970s. Although the essay concerns "the Rise of the Pornographic Feature" he concludes with an unsupported claim that the narrative feature adult sex film was a temporary phenomenon. ${ }^{58}$ The existence of Pirates and similar films contradicts that conclusion.

Other works on the relationship between sex films and the mainstream film industry are Justin Wyatt's "The Stigma of X: Adult Cinema and the Institution of the

\footnotetext{
${ }^{55}$ Williams, Hard Core, 267.

${ }^{56}$ Linda Williams, Screening Sex (Durham: Duke University Press, 2008).

${ }^{57}$ Linda Williams, ed., Porn Studies (Durham: Duke University Press Books, 2004).

${ }^{58}$ Eric Schaefer, "Gauging a Revolution: 16mm Film and the Rise of the Pornographic Feature," in Porn Studies (Durham: Duke University Press Books, 2004), 370-400.
} 
MPAA Ratings System" (1999), Jon Lewis' Hollywood v. Hard Core: How the Struggle over Censorship Saved the Modern Film Industry, (2000) and The Naked Truth: Why Hollywood Doesn't Make X-Rated Movies (2007). Wyatt covers the relationship from the late 1960s to the mid-1970s, when sex films became mainstream and Hollywood flirted with the $\mathrm{X}$ rating. ${ }^{59}$ Lewis provides a broad history of the relationship between Hollywood and sex films, acknowledging contributions from Williams, Wyatt, Sandler, and Schaefer ${ }^{60}$ Sandler focuses more on the R/NC-17 boundary, and has the advantage of access to primary source material about the MPAA that was archived in $2005 .{ }^{61}$

Except for Williams', these academic histories of adult sex films largely ignore social concerns about pornography. They freely refer to the period from the mid-1970s to mid-1980s as The Golden Age, and to some films from that era, such as Deep Throat (Gerard Damiano, 1972) as classics. While there are factors that make that era and some of its films significant, the terms Golden Age and classic are signs of what Susanna Paasonen and Laura Saarenmaa identify as a tendency to romanticize and consequently obscure the past. Their 2007 essay "The Golden Age of Porn: Nostalgia and History in Cinema" is a cautionary note for the preparation of sex film histories. ${ }^{62}$

\footnotetext{
${ }^{59}$ Justin Wyatt, "The Stigma of X: Adult Cinema and the Institution of the MPAA Ratings System," in Controlling Hollywood: Censorship and Regulation in the Studio Era, ed. Matthew Bernstein (New Brunswick, N.J: Rutgers University Press, 1999), 238-63.

${ }^{60}$ Jon Lewis, Hollywood v. Hard Core: How the Struggle Over Censorship Created the Modern Film Industry (New York: NYU Press, 2002).

${ }^{61}$ Kevin S. Sandler, The Naked Truth: Why Hollywood Doesn't Make X-Rated Movies (New Brunswick, N.J: Rutgers University Press, 2007).

${ }^{62}$ Susanna Paasonen and Laura Saarenmaa, "The Golden Age of Porn: Nostalgia and History in Cinema," in Pornification: Sex and Sexuality in Media Culture, ed. Kaarina Nikunen, Susanna Paasonen, and Laura Saarenmaa (Oxford ; New York: Bloomsbury Academic, 2008), 23-32.
} 
Much of the work on pornography, with or without consideration of the film industry, tends to focus on pornography from the United States. This is not unreasonable, given its dominance, but tends to obscure the issue in other countries. As noted above, "Obscenity and Community Standards" compares obscenity law in Canada and the United States. International Exposure: Perspectives on Modern European Pornography 1800-2000, (2005) provides non-American views on the industry, and some of the essays provide information relevant to pornography or media regulation. ${ }^{63}$

\subsection{Ratings in Canada}

There is relatively little work on film censorship and ratings systems in Canada. This may in part be due to the fragmented nature of the ratings systems: There is no national authority to attract widespread attention, criticism, or review, and such controversies as do occur are restricted to one province.

The key source for Canadian film ratings history, until 1980, is Malcolm Dean's Censored! Only in Canada: The History of Film Censorship - the Scandal off the Screen (1981). As the title suggests, this book maintains that censorship is inherently wrong, and provides a history of censorship to support this argument. Though Dean is clearly biased, the book is a goldmine of information about the development of ratings systems in every province and territory of Canada. ${ }^{64}$

\footnotetext{
${ }^{63}$ Lisa Z. Sigel, International Exposure: Perspectives on Modern European Pornography, 1800-2000 (New Brunswick, N.J: Rutgers University Press, 2005).

${ }^{64}$ Dean, Censored!
} 
The otherwise thorough and more rigorously academic Interpreting Censorship in Canada, from 1999, did not include a chapter on film censorship, deferring to Dean's Censored! While this is a strong endorsement of Dean, the editors missed an opportunity to address almost two decades of history. The only acknowledgement of changes in the film regulatory climate since 1981 is the inclusion of a 1984 Ontario court decision concerning the powers of that board. ${ }^{65}$ The end result was just the renaming of the Ontario Board and amendments to the Theatres Act, but the editors curiously refer to this case as "a turning point in the history of Canadian film censorship." ${ }^{66}$ There is no mention of the effect and implications of the Butler decision on film review boards, a significant oversight. Butler, a 1992 Canadian Supreme Court case concerning pornographic home videos, established the current obscenity law, thus providing a guideline and tests for film review agencies.

A recent though brief historical survey of Canadian film censorship is Pierre Véronneau's essay "When Cinema Faces Social Values: One Hundred Years of Film Censorship in Canada," in the 2013 anthology Silencing Cinema: Film Censorship around the World. Like Dean, Véronneau is clearly opposed to censorship, and this survey emphasises developments in Quebec. However, his essay supplements Dean's history. ${ }^{67}$

\footnotetext{
${ }^{65}$ Re Ontario Film and Video Appreciation Society and Ontario Board of Censors (1984) 45 O.R. (2d) 80 (C.A.) (Supreme Court of Ontario 1984).

${ }^{66}$ Allan C. Hutchinson and Klaus Petersen, Interpreting Censorship in Canada (University of Toronto Press, 1999), 404.

${ }^{67}$ Pierre Véronneau, "When Cinema Faces Social Values: One Hundred Years of Film Censorship in Canada," in Silencing Cinema: Film Censorship around the World, ed. Daniel Biltereyst and Roel Vande Winkel, Kindle (New York, New York: Palgrave Macmillan, 2013), 49-52.
} 
An informative analysis of the Ontario board's operations and ratings process, with regard to Restricted and Adult Sex films, is Siobhan Devine's 2003 personal documentary, My Tango with Porn. Devine, who identifies as a lesbian filmmaker, joined the board opposed to censorship and keen to "shake things up." ${ }^{68}$ She soon found herself censoring adult sex films, and was a member of the panel that recommended a cut for the controversial French exploitation film Baise-moi (Virginie Despentes and Coralie Trinh Thi, 2000). Apart from providing insight into the operations of the board, the circumstances of requesting a cut to a film that played uncut at a film festival is relevant to the discussion of classifying festival films in chapter nine.

In 2003, Raymond Lee prepared Research on Community Standards for British Columbia Film Classification. This report includes a summary of Canadian obscenity law cases and comparisons of film ratings among English language agencies in Canada. Lee found British Columbia to have the least restrictive ratings. ${ }^{69}$ This data will be compared with the analysis of provincial ratings in chapter six.

\subsection{Adult Sex Films in Canada}

The classification agencies in Canada, except in Alberta, review and approve adult sex films as well as theatrical releases. My Tango with Porn, noted above for its information on the general operations of the Ontario Film Review Board, includes information about reviewing adult sex films. There is also some material about the adult

\footnotetext{
${ }^{68}$ Siobhan Devine, My Tango with Porn, VHS, Documentary, (2003).

${ }^{69}$ Raymond Lee, Research on Community Standards. (Vancouver: British Columbia Film Classification Office, 2003), www.bcfilmclass.com/publications/cs2004.pdf (Accessed 2005, no longer available).
} 
film industry in Canada on the Canuxploitation web site. ${ }^{70}$ Otherwise, the available literature is primarily concerned with the broader issues of obscenity or pornography.

The literature on pornography in Canada, like the general literature on pornography, divides into the For and Against camps, and they are easily recognized by their response to Butler. Those who take the position that all pornography is bad feel Butler does not go far enough, while those who accept or embrace pornography feel it goes too far.

Kirsten Johnson's 1995 Undressing the Canadian State: The Politics of Pornography from Hicklin to Butler, is a useful though incomplete summary of the legal cases in Canada concerning obscenity law up to and including Butler, including those directly affecting film regulations. Johnson concludes Butler is inadequate to address problems of women's inequality, in part due to its reliance on community standards. She notes it is too soon to see how Butler will be applied, but is not optimistic, stating "the court's lack of vision contributes to and legitimates the pornographic status quo."71

Strossen's Defending Pornography takes the opposite position on Butler. Strossen is primarily concerned with issues in the United States, but she uses Butler and some post-Butler decisions as examples of the many harms, including harms to women, of laws attempting to restrict pornography. Strossen notes that to describe any sexual act as

\footnotetext{
70 "Canuxploitation! Your Complete Guide to Canadian B-Film," accessed January 9, 2015, http://www.canuxploitation.com/.

${ }^{71}$ Kirsten K. Johnson, Undressing the Canadian State: The Politics of Pornography from Hicklin to Butler (Halifax: Fernwood Pub, 1995), 86.
} 
inherently degrading to women denies individual women the choice to determine for themselves whether a particular act is degrading or pleasurable. ${ }^{72}$

Canadian May Friedman takes a similar perspective in her 2002 MA thesis, "Working Out the Kinks: Advancing the Pornography Debate." Her focus is the actions of the courts and customs, but some of the material is relevant to the classification of adult sex films. Friedman, like the other writers mentioned both for and against Butler, claims to analyze Butler from a feminist perspective. ${ }^{73}$ Like Strossen, she considers the Butler decision repressive for female sexuality. Boyce analyses Butler from a legal perspective, and finds that "despite Butler's egalitarian rhetoric, the implementation of the new standard has been repressive and discriminatory."74

A 2005 obscenity case concerning a sex club, R. v. Labaye, placed greater emphasis on harm rather than community standards, and in 2009 Richard Jochelson claimed Labaye meant the retirement of community standards. ${ }^{75}$ He acknowledged that "while the meaning of Butler has not been altered dramatically, its language has been tweaked" and the effect of the change has yet to be determined. ${ }^{76}$

Max Waltman looked at the application of Butler in 2010, in "Rethinking Democracy: Legal Challenges to Pornography and Sex Inequality in Canada and the

\footnotetext{
72 Strossen, Defending Pornography, 154-155.

${ }^{73}$ May Friedman, "Working Out the Kinks : Advancing the Pornography Debate" (ProQuest, UMI Dissertations Publishing, 2002), https://curve.carleton.ca/theses/26514.

${ }^{74}$ Boyce, Obscenity and Community Standards, 333.

${ }^{75}$ R. v. Labaye [2005] 3 SCR 728. ; Richard Jochelson, "After Labaye: The Harm Test of Obscenity, the New Judicial Vacuum, and the Relevance of Familiar Voices," Alberta Law Review 46, no. 3 (2009): 767.

${ }^{76}$ Jochelson, "After Labaye," 766.
} 
United States." Waltman concludes that Johnson was correct with regard to Butler being inadequate. He makes no mention of the Labaye case, suggesting it did not have the effect Jochelson thought it might. Waltman is sharply critical of the level of sexual violence that has been permitted in court cases since Butler, such as Regina v Price $(2004){ }^{77}$

One of the videos in that case included a man urinating into a woman's mouth while she is bent backwards over a toilet. When she does not swallow all the urine, he punishes her by pushing her head into the toilet bowl. The court ruled there was "reasonable doubt that the contemporary Canadian community would not tolerate other Canadians viewing" the video. ${ }^{78}$ The video in question was only for internet distribution, and therefore outside of the jurisdiction of any film classification agency. However, the judge cited high levels of sexual violence in agency approved mainstream films such as American Psycho (Mary Harron, 2000), Baise-moi and Irreversible (Gaspar Noé , 2002) as evidence that the community would tolerate the video. ${ }^{79}$

Waltman notes that the high level of sexual violence in mainstream films should have been troubling in and of itself, rather than used as justification for allowing this video, effectively placing himself outside of the dominant anti-censorship position with regard to mainstream films. However, this is consistent with his argument that democratic governments cannot control pornography, and that government film classification agencies are part of the problem. For example, Waltman suggests that a man ejaculating

\footnotetext{
${ }^{77}$ Max Waltman, "Rethinking Democracy: Legal Challenges to Pornography and Sex Inequality in Canada and the United States," Political Research Quarterly 63, no. 1 (March 2010): 218-37.

${ }^{78}$ Regina v. R. Price 20040423 BCPC 0103 (British Columbia 2004).

${ }^{79}$ Ibid.
} 
into a woman's mouth is inherently dehumanizing for women. ${ }^{80}$ This act has been accepted by classification agencies for many years.

The history of film censorship in the United States, the MPAA ratings system, and the history and operations of the American sex film industry, are well researched and there is a substantial body of literature. In Canada, there is little or no literature on the ratings systems and the sex film industry. There are no broad comparisons of film ratings between Canada and the United States, despite the shared film market with different rating systems. There are a few international comparisons of ratings, but these single out a specific province, or address only one classification. This thesis seeks to address the many gaps in the literature on film classification in Canada.

\footnotetext{
${ }^{80}$ Waltman, "Rethinking Democracy," 232. Waltman acknowledges that obscenity regulations can be used to repress gay men, but is silent on matters such as whether a man ejaculating into another man's mouth, or his own, is dehumanizing for anyone.
} 


\section{History}

Film censorship in the United States and Canada can be considered as having four stages: Origins (1894-1911), the Censorship Era (1911-1935), the Production Code Era (1935-1968), and the current Ratings Era. These are broad categories with overlaps and exceptions. For example, censorship started with municipal governments in both countries, in Chicago, New York and Toronto, and is therefore usually associated with the origins of censorship, but Dallas, Texas, had a municipal censor board from 1966 to 1993. ${ }^{81}$ However, for the purposes of comparing the divergent paths of Canadian and American censorship, these stages are useful.

This chapter outlines key developments in the first three stages. Significant developments since 1968 will be noted in the next chapter's history of adult films, however by that year the major elements of ratings systems for mainstream films were essentially the same as they are today

\subsection{Origins - United States}

Film content regulation is as old as the film industry. Edison introduced his Kinetoscope in 1894. In July of that year, on the first evening a machine was exhibited in Ashbury Park, New Jersey, the films were viewed by a Senator and the town's mayor. The men concluded that one of the films, featuring a female Spanish dancer, was not appropriate, and threatened to shut down the attraction unless the film was replaced by

\footnotetext{
${ }^{81}$ Phillips, "Not Suitable in Dallas : Movies: Dentist Fred Aurbach Presides over the Only Big-City Film Ratings Board in the Country--a Thorn in Distributors' Sides."
} 
something more suitable. The distributor complied, and replaced the objectionable film with Boxing Cats. ${ }^{82}$

During the following decade, moral crusaders, newspapers, and chapters of the Society for the Suppression of Vice occasionally attempted to prevent the exhibition of certain films or close film parlours. In 1907, Chicago and New York passed laws to control the moral content of films. ${ }^{83}$

In 1909, the Motion Pictures Exhibitors Association formed The Committee on Censorship, composed of volunteers from various social organizations, which reviewed and approved all films for New York. Within a year, the Committee renamed itself The National Board of Censorship of Motion Pictures. ${ }^{84}$ The Board shared their decisions with distributors nationwide, and campaigned against proposed municipal and state censorship initiatives. However, the Board was criticised for being too close to the industry, too liberal (by various groups, including the Motion Picture Exhibitors League of America), too conservative (by other film distributors), ineffective as they did not ensure ordered cuts were actually made, and, as a New York agency, unable to appreciate concerns in the rest of the country. ${ }^{85}$

\footnotetext{
82 Tropiano, Obscene, Indecent, Immoral \& Offensive, 4-5. Other sources claim the incident took place in 1896. Some sources claim the film was Dolorita and the Passion Dance, but that film is generally dated 1897. Charles Musser notes that many "belly dance" films were not listed in catalogues, and may have been sold discreetly. Edison Motion Pictures, 1890-1900: An Annotated Filmography (Gemona (UD) Italy; [Washington, D.C.]: Giornate del cinema muto ; Smithsonian Institution Press, 1997), 132. Boxing Cats has lately been called the earliest example of a cat video, and is available online.

83 Tropiano, Obscene, Indecent, Immoral \& Offensive, 5-13.

${ }^{84}$ Ibid., 14-15.

${ }^{85}$ Ibid., 16-17. ; Couvares, "Hollywood, Main Street, and the Church," 131.; Goldstein, "The Motion Picture and Social Control," 211.
} 
Meanwhile, the shift to longer films, projected in purpose built theatres, drew more attention to fire safety and the moral hazards of people gathering in dark auditoriums. Jurisdictions around the world began setting up boards to set moral and building standards for movie theatres. ${ }^{86}$ More American cities established censor boards, and Pennsylvania established the first state board in 1911.

\subsection{Origins - Canada}

Vitascope films were shown in Toronto as early as 1896, and moral crusaders with concerns about films, theatres, and children quickly followed. ${ }^{87}$ In 1907, the Toronto Mail and Empire reported that the city was considering censorship of "5-cent theatres."188 A 1908 court case in Quebec established that theatres were subject to Sunday closing laws, and that year Toronto city council asked the police to suspend issuing licences for theatres, pending the city's request that the province regulate theatres. ${ }^{89}$

On March 24, 1911, Manitoba, Ontario and Quebec passed laws allowing the provincial governments to censor films. They were followed by New Brunswick in 1912, British Columbia, Alberta, and Saskatchewan in 1913, and Nova Scotia in 1915. ${ }^{90}$

${ }^{86}$ Dean, Censored!, 11-13.

${ }^{87}$ Wyndham Wise, "History of Ontario's Film Industry, 1896 to 1985," Take One, 2000, 1, 216183924, ProQuest, http://proxy.library.carleton.ca/login?url=http:

//search.proquest.com.proxy.library.carleton.ca/docview /216183924?accountid=9894.

${ }^{88}$ Dean, Censored!, 13.

${ }^{89}$ Ibid., 14-15.

${ }^{90}$ Newfoundland, though then not part of Canada, established film censorship in 1916. The North West Territories began requiring films to be approved in 1938, but has always used the approval or classification of other jurisdictions, usually Alberta. Although Manitoba started censorship in 1911, for the first five years the City of Winnipeg reviewed the films, as the only theatres in the province were in Winnipeg. 
The film industry in Canada was little more than a handful of importers, and unlike the United States (and the United Kingdom), it was not powerful enough to organize self-regulation. In 1913, distributors challenged a ban in Quebec, and lost. ${ }^{91}$ This paved the way for the agencies to operate without hindrance.

\subsection{Censorship Era - US}

When the Pennsylvania board was established, the film industry fought back with various legal maneuvers. ${ }^{92}$ The constitutional legality of film censorship was settled in 1915, by the United States Supreme Court, in the Mutual case. The Court ruled that movies were not protected speech and could be censored. The opinion stated:

The exhibition of moving pictures is a business, pure and simple, originated and conducted for profit like other spectacles, and not to be regarded as part of the press of the country or as organs of public opinion within the meaning of freedom of speech and publication guaranteed by the Constitution of Ohio. ${ }^{93}$

The National Board of Censorship changed its name to the less threatening National Board of Review in 1915, but widespread dissatisfaction with it, and the movement of the film industry from New York to Hollywood, reduced its relevance and authority. ${ }^{94}$ A congressional bill to set up federal censorship failed, but distributors grew

${ }^{91}$ Dean, Censored!, 20.

92 In 1919, the Ontario Board of Censors defended itself against accusations of liberalism by noting they had banned films that had been allowed in Pennsylvania. Ibid., 136. A 1930 study of censorship found Pennsylvania was the strictest. Tropiano, Obscene, Indecent, Immoral \& Offensive, 21.

93 "Mutual Film Corp. v. Industrial Comm'n of Ohio 236 U.S. 230 (1915)," Justia Law, accessed January 7 , 2015, https://supreme.justia.com/cases/federal/us/236/230/.

94 The National Board of Review continued to approve films into the 1950s, has published a series of film journals, and supports film students. In 1930 it started recognizing the ten best American and foreign films of the year, and continues to present annual film awards. 
increasingly concerned about that possibility, and several more states and cities started censorship offices. ${ }^{95}$

The film industry created a new review organization, the National Association of the Motion Picture Industry (NAMPI), in 1916, but it stalled after adopting content resolutions. ${ }^{96}$ The industry tried again in 1922, this time without the participation of exhibitors, and created the Motion Picture Producers and Distributors of America (MPPDA), later known as the Motion Picture Association of America (MPAA). The MPAA recruited an industry outsider with Washington connections, postmaster general William Hays, to serve as president. The MPPDA's goals included regulating the content of all films and film advertising, through a Committee on Public Relations. Like the National Board of Review, the Committee consisted of volunteers from a wide range of social organizations. ${ }^{97}$ The Committee was not effective, and Hays restructured it as the Department of Public Relations, later known as the Studio Relations Office. In 1930 the Office issued a Production Code, but it remained unenforced. Finally, in 1935, Hays ended the participation of volunteers and set up the Production Code Administration (PCA), which had the authority to enforce Code compliance on the studios, and the distributors and theatres they owned. ${ }^{98}$

\footnotetext{
${ }^{95}$ Tropiano, Obscene, Indecent, Immoral \& Offensive, 17-18.

${ }^{96}$ Ibid., 28-29.

${ }^{97}$ Couvares, "Hollywood, Main Street, and the Church," 132.

${ }^{98}$ Tropiano, Obscene, Indecent, Immoral \& Offensive, 31-33.; Goldstein, "The Motion Picture and Social Control," 216-218.
} 


\subsection{Censorship Era - Canada}

Canadian censorship agencies had the same content concerns as American censors, with one addition: In recognition of Canadian nationalism and concerns about American influence, the agencies removed gratuitous depictions of the American flag. ${ }^{99}$

Typical reasons for rejecting films in 1914 included:

- Sordid scenes of drunkenness in Underworld (Way to Heaven),

- White Slavery (Sealed Orders),

- Infidelity (Moth and Flame),

- U.S Flags (A Blowout at Santa Banana), and

- Depiction of insanity for comedy purposes (Tom's Choice). ${ }^{100}$

A common clause of the Theatres Acts required children under fifteen or sixteen to be accompanied by an adult for all shows. This was more restrictive than American regulations, but it also meant censors did not have to ensure all films were suitable for unaccompanied children. In both Canada and the United States, protection of children was a significant factor in the calls for censorship, but only Canada followed through with regulations specifically protecting children.

Unlike the United States, film censorship in Canada was clearly a provincial matter. During World War I, although censorship of films was included in the War Measures Act, the provincial censors were responsible for controlling the content of

\footnotetext{
${ }^{99}$ Wise, "History of Ontario's Film Industry, 1896 to $1985, " 1-2$.

100 "Rejection List for the Week Ending April 11, 1914," April 11, 1914, GR-490 Box 8, Archives of British Columbia. As government organizations, the film classification agencies submit records to provincial archives, however the amount and type of information submitted varies. The Archives of British Columbia include correspondence and records concerning film cuts and bans, from about 1914 to 1963 , a valuable resource. Correspondence from 1963 to the early 1980s was not retained. Archived film agency records in Ontario and Nova Scotia do not include this type of correspondence. Archival collections in other provinces have not been examined. Records not yet archived can be difficult to obtain, due to the cost of filing Freedom of Information requests, or apparent lack of formal record keeping policies.
} 
feature films and newsreels. ${ }^{101}$ The fallout from the war included soldiers bringing home sexually transmitted diseases. Disease prevention films originally prepared for military showings, such as The End of the Road (Griffith, 1919), were publicly distributed at the urging of various social organizations. Admission was age restricted and showings were sexually segregated. ${ }^{102}$ These films faced similar restrictions on admission and periodic bans in the United States. ${ }^{103}$

The common launch date for several of the Theatres Acts, and the similar wording of the Acts, indicates the high degree of cooperation between the Boards, resulting in more consistent operations than in the United States. The provincial censors met in Toronto in 1921, and agreed on a variety of resolutions, including moving to a single national system using the Ontario standards, and banning all films with German propaganda. ${ }^{104}$ They met in Montreal in 1922, and agreed to remove the "Passed by National Board of Review" leader from American films. They also agreed to ban films that reflected badly on the North West Mounted Police. The censor for Alberta then proposed that the issue of German films be left to the discretion of the provinces. This turned out to be a sensitive issue: "...after long discussion, the Association decided that provincial standards must be left under provincial regulations, as each province has a

\footnotetext{
101 Jeff Keshen, Propaganda and Censorship During Canada's Great War (University of Alberta, 1996), $66,73,106-110$.

102 Dean, Censored!, 25.

103 Tropiano, Obscene, Indecent, Immoral \& Offensive, 50.

104 "OFRB Chair's Correspondence." This information is from the minutes, prepared by Mr. Robson, representing Saskatchewan. Alberta, Manitoba, Quebec and Nova Scotia were also represented.
} 
different class of people to deal with." 105 It was almost forty years before the censors met again.

Restrictions on unaccompanied children were dropped or modified over time. Ontario permitted unaccompanied children during the day on Saturdays and holidays, provided a matron was on duty to "supervise the conduct of such children and of adults toward them. ${ }^{\prime 106}$ Quebec allowed unaccompanied children to shows specifically designated appropriate by the censors, but after a 1927 fire at a Montreal theatre led to the death of seventy-eight children, the Quebec government banned children under sixteen from theatres, accompanied or not. Children could still view films at parish halls. $^{107}$

\subsection{Production Code Era - United States}

As noted in The Movies on Trial, when the Production Code Administration fully implemented its Code in the mid-1930s, there was a sense that the issue of morality in the movies had been resolved. However, foreign films and films from smaller studios were not covered by the Production Code, independent theatres showed films that were not Code approved, and some film makers challenged the Code. Howard Hughes openly fought both censors and the Production Code over his sexy western, The Outlaw (1943),

\footnotetext{
${ }^{105}$ Dean, Censored!, 47.

${ }^{106}$ R.S.O 1927, Chapter 285, section 9 (Emphasis added).

107 "The Laurier Palace Theatre Fire," May 22, 2010, http://silenttoronto.com/?p=92.
} 
the debut film of Jane Russell. The final print, cut by more than twenty minutes, reflected the authority of state censors and validated the pro-censorship position of the PCA. ${ }^{108}$

Until 1942, MPAA member theatres that showed non-Code approved films faced a $\$ 25,000$ fine from the PCA, but an amendment quietly removed the penalty. ${ }^{109}$ The antitrust Paramount Decrees arising out of Paramount v. United States in 1948 forced the major studios to sell their theatre chains, further weakening the ability of the PCA to ensure theatres only showed Code approved films. ${ }^{110}$

Exploitation films from independent studios, and foreign films, kept state and local censors busy. The former films tackled subjects not permitted by the PCA, such as illegitimacy and drug use, or featured ample female nudity in educational, documentary, or artistic contexts. It was a considerably more artistic foreign film that led to a major change in American film censorship.

In 1950, New York state censors approved Ways of Love, a collection of short Italian films. One of them, Il Miracolo (Rossellini, 1948), is about a pregnant peasant who believes she is the Virgin Mary. The film was widely criticized for blasphemy, and in 1951 the state censors banned the film on the grounds of sacrilege. The distributor appealed to the New York courts, and lost; to the State Appeal courts, and lost; and finally to the U.S. Supreme Court. In 1952, that Court ruled that films were entitled to the

\footnotetext{
108 Tropiano, Obscene, Indecent, Immoral \& Offensive, 61-70.

109 Ibid., 69.

110 "United States v. Paramount Pictures, Inc. 334 U.S. 131 (1948)," Justia Law, https://supreme.justia.com/cases/federal/us/334/131/case.html.
} 
free speech provisions of the First Amendment, reversing the Mutual decision. The ruling is generally referred to as the Miracle decision. ${ }^{111}$

The ruling did not stop states from banning obscene films, but when state censors attempted to ban exploitation films such as The Garden of Eden (Max Nosseck, 1954), which features nudity of women and children at a nudist camp (in colour), bans were overturned by the court and in some cases state censors declared unconstitutional. ${ }^{112}$ The definition of obscenity soon changed.

Until 1957, the United States relied on a definition of obscenity from an 1868 British case, R. v. Hicklin. It was any material which would "deprave or corrupt those whose minds are open to such immoral influences." 113 The U.S. Supreme Court Roth decision ended reliance on Hicklin, and set new tests, including the needs to consider the entire work and community standards. ${ }^{114}$ This made it more difficult to obtain an obscenity conviction for any material. Prior restraint censorship and censorship of films in the United States was mostly eliminated by the mid-1960s. ${ }^{115}$

The PCA was not directly affected by the Miracle or Roth decisions, or the closing of state censors. Code approved films generally did not face obscenity charges or state censoring, and the PCA carried on with the same standards as before. However, in

\footnotetext{
111 "Joseph Burstyn, Inc. v. Wilson 343 U.S. 495 (1952)," Justia Law, accessed January 7, 2015, https://supreme.justia.com/cases/federal/us/343/495/.

112 Schaefer, Bold! Daring! Shocking! True, 329-330.

${ }^{113}$ R. v. Hicklin [1868] LR 3 QB 360 (1868).

114 "Roth v. United States 354 U.S. 476 (1957)," Justia Law, https://supreme.justia.com/cases/federal/us/354/476/case.html.

115 Schaefer, Bold! Daring! Shocking! True, 329-330. State and municipal censor boards carried on in some areas. For example, state censors in Maryland banned Snuff in 1976, and circuit court upheld the ban on the grounds that the film was obscene. Tropiano, Obscene, Indecent, Immoral \& Offensive, 174-175. As noted previously, Dallas instituted municipal censorship in 1966, and maintained it until 1993.
} 
the face of declining censorship and challenging films, the PCA became increasingly irrelevant.

Major studios released a few daring films such as The Moon is Blue (Otto Preminger, 1953) and The Man with the Golden Arm (Otto Preminger 1955) without Code approval. The Moon is Blue (Otto Preminger, 1953) is a sex comedy of two men, played by David Niven and William Holden, trying to seduce a woman. Based on a play, it was shocking at the time for frank words such as virgin, seduce, pregnant, and mistress. The Man with the Golden Arm, based on a book, features Frank Sinatra as a poker dealing ex-convict, struggling to escape from heroin addiction. These were commercial and critical successes. Pre-marital sex and drug addiction were not subjects the PCA could approve, but the public was ready for this in films, at least in films with respected performers and artistic origins.

The PCA finally responded to changing mores by becoming slightly more liberal. In 1960, the PCA began issuing age restrictions of 16 or 18 for some films, requiring adult accompaniment for persons under that age. The use of age restrictions allowed them to approve more material. In 1965, the PCA approved The Pawnbroker (Sidney Lumet, 1964), starring Rod Steiger. This black and white film was the first Code approved film with images of topless women, but by this time colour exploitation films with fully nude women had been available for at least a decade. The Code still seemed out of date.

In 1966 the MPAA hired Jack Valenti to run the PCA. Like William Hays, Valenti had no experience with films and connections in Washington. Valenti moved swiftly to update the Production Code. ${ }^{116}$ Two years later, a major Code revision brought

${ }^{116}$ Tropiano, Obscene, Indecent, Immoral \& Offensive, 90. 
in four levels of classification: $\mathrm{G}$ (General), for all ages; M, for Mature audiences; R, for Restricted to adults and children accompanied by adults; and X, for adults only. Significantly, the $\mathrm{X}$ rating could be applied by film makers without submitting their film for classification. The name of the ratings agency changed from Production Code Administration to Code and Ratings Administration (subsequently changed to Classification and Ratings Administration in 1977). As Tropiano points out, the MPAA mythologizes the initiation of ratings in 1968 as a complete change from, in Valenti's words, "the old and decaying Hays Production Code," but apart from introducing ratings, a not insignificant move, very little changed. ${ }^{117}$ The old standards and guidelines remained, though in some cases with less weight. ${ }^{118}$

\subsection{Production Code Era - Canada}

The American Production Code made work easier for Canadian censors. In 1937, the long serving chair of the Ontario Board, Omri Silverthorne, noted in his annual report that British films required more cuts than American films, due in part to the use of language not permitted in Hollywood films. ${ }^{119}$

This does not mean all Code approved films were permitted, or uncut. British Columbia and Ontario both banned Angels with Dirty Faces (Michael Curtiz, 1938). The Outlaw was banned in Quebec. ${ }^{120}$ It was initially approved for BC with one line of

\footnotetext{
${ }^{117}$ Ibid., 91.

${ }^{118}$ Sandler, The Naked Truth, 38.

119 "British Films Smuttier, Can. Censor Says," Variety, June 27, 1937.

${ }^{120}$ Dean, Censored!, 159.
} 
dialogue cut, but later banned after complaints. ${ }^{121}$ British Columbia also banned all horror films for the duration of the World War Two.

Age restrictions and content warnings had been long been used periodically in the United States and Canada, usually for sexual health films, but some agencies in Canada started routinely using classification for other early films. In 1935, British Columbia approved Bride of Frankenstein (James Whale, 1935), "with the understanding that it must be shown to adults only."122 The following year, Bengal Tiger (Louis King, 1936) was approved on the condition that the trailer and the feature have a leader stating "BENGAL TIGER is not recommended for small children or nervous people." 123 By the mid-1930s, the practice of classifying films for age appropriateness was common. Manitoba classified all films as either General or Adult, but had no admission restrictions. ${ }^{124}$ Alberta also had two classifications, but did not classify newsreels or comedies, and required adult accompaniment for children under fourteen attending Adult films. ${ }^{125}$ In 1946, Ontario made classification mandatory for all films, and soon introduced a Restricted classification to identify films for adults only. ${ }^{126}$ The only agency that did not introduce some form of age classification was Newfoundland. Instead,

\footnotetext{
121 "Re: The Outlaw - Approved with Cut," October 8, 1946, GR-490 Box 6, Archives of British Columbia.; "Re: The Outlaw - Protests," November 4, 1946, GR-490 Box 6, Archives of British Columbia.

122 "Re: Bride of Frankenstein," May 22, 1935, GR-490 Box 5, Archives of British Columbia.

123 "Re: Bengal Tiger," September 11, 1936, GR-490 Box 5, Archives of British Columbia.

${ }^{124}$ Government of Manitoba, "Manitoba Film Classification Board."

${ }^{125}$ Dean, Censored!, 110.

${ }^{126}$ Ibid., $139-140$.
} 
Newfoundland abandoned censorship in $1947 .{ }^{127}$ It was not until 1960 that the American PCA started using age classification.

National adoption of age classifications did not stop provincial differences in approving films. Lady Chatterly's Lover (Marc Allégret, 1955) and ...And God Created Woman (R. Vadim, 1956) were approved in Ontario, but banned in British Columbia. The Wild One (Laslo Benedek, 1953) was banned in Alberta, but approved in other provinces. ${ }^{128}$ American exploitation films continued to be banned by all jurisdictions.

Notwithstanding the bans, the agencies continued to become more liberal and place greater emphasis on providing information. Manitoba introduced a Restricted classification in 1959, in order to permit the showing of La Ronde (Max Ophüls, 1950), a stylish French sex comedy. ${ }^{129}$ British Columbia introduced the distinctive Cougar logo to identify Restricted films in 1960 and, in 1966, began routinely using warnings in addition to classification. ${ }^{130}$

Some of the drive for liberalization came from censors themselves. In the early 1960s, Ontario chair Silverthorne spoke out against censorship, stating "the rigid inflexibility, the inability to adapt to the changing outlook of the Canadian people, the conflicting decisions and inconsistencies have succeeded in making censorship look

\footnotetext{
${ }^{127}$ Ibid., 132.

${ }^{128}$ Ibid., 113. Other sources claim the film was also banned in British Columbia and Quebec.

${ }^{129}$ Government of Manitoba, "Manitoba Film Classification Board." La Ronde had also been one of the first Restricted films approved in Ontario. Dean, Censored!, 140.

130 "The Restricted Cougar," Consumer Protection BC, accessed January 12, 2015, http://www.consumerprotectionbc.ca/consumers-film-and-video-homepage/consumer-tips/1028.;Dean, Censored!, 121. The Restricted Cougar was trademark protected in 1966. It was used for advertising and in announcement trailers preceding Restricted films, until 1997. It is still used for Restricted home video.
} 
ridiculous in the eyes of the people we seek to serve." ${ }^{131}$ A few years later he noted "banning any film today only arouses controversy and brings it a publicity value it does not deserve."132

External forces, including television and changes to obscenity law, also encouraged liberalization. Provincial censors had no authority over television broadcasts, as broadcasting regulations are a federal responsibility, and $\mathrm{CBC}$ routinely aired uncut versions of films previously censored or banned. ${ }^{133}$ While censors have never been obliged to follow obscenity law, they generally look to it as a guideline on what is permissible, and respond to changes in the law.

As in the United States, Canada long relied on Hicklin for a definition of obscenity. Three years before Roth, Canadian courts ruled in 1954 that obscenity required consideration of community standards, and that any potentially obscene work should be judged in its entirety. Parliament passed an updated obscenity law in 1959 to reflect this. A Supreme Court case in 1962 confirmed that material was only obscene if the

\footnotetext{
131 Wise, "History of Ontario's Film Industry, 1896 to $1985, " 4$.

132 Dean references this quote to a newspaper article from 1965, but other sources claim the quote is from 1963. This may be when the quote was repeated by another source. Dean, Censored!, 141 .

${ }^{133}$ Ibid., 67. The Canadian Broadcast Standards Council, an industry group of private broadcasters, established television ratings in 1997. English language broadcasters have unique categories and symbols. French language broadcasters use the categories and symbols of the Régie du cinéma du Québec, with the addition of an 8+ category (not suitable for young children) but must perform their own evaluation of the material, even if it has previously been classified by the Régie, on the grounds that watching television is different from watching a film. "Canadian Broadcast Standards Council," Ratings Classifications, accessed January 6, 2015, http://www.cbsc.ca/english/agvot/ratings.php. Netflix uses maturity ratings based on the television categories of the customers' market. https://help.netflix.com/en/node/2064. Rogers Cable rates at least some of its content following the practices and standards of the Ontario Film Review Board. (Personal communication with a member of the Board, September, 2005.)
} 
community would not tolerate it. ${ }^{134}$ In 1964, another Supreme Court case established that the community was Canada as a whole. ${ }^{135}$ The United States has never defined community and it does not need to be defined in a trial. As of 1964, several provinces were approving films with nudity. This was the same year the PCA approved a film with nudity.

By the late 1960s, the provincial and MPAA classification systems were essentially the same as they are today. The agencies focused on determining the appropriate ages for films and providing information. Censorship based on moral concerns, public welfare, or political issues was gone, and the primary concerns (and eliminations) were sexual imagery in increasingly explicit films. Some of these films were mainstream Hollywood product, some were art or foreign films with limited exhibition, and some were sexual exploitation films. How these concerns were addressed will be discussed in the following chapter.

\footnotetext{
${ }^{134}$ Brody, Dansky, Rubin v. The Queen (1962) SCR 681, accessed January 7, 2015. The case is also known as R. v. Brodie.

${ }^{135}$ Dominion News \& Gifts (1962) Ltd. v. The Queen [1964] SCR 251, accessed January 7, 2015.
} 


\section{Legalization of Adult Sex Films}

The one significant change in film classification and approval in Canada since the late 1960s has been the legalization of adult sex films. These films are typically defined as "film that has, as its main object, the depiction of explicit sexual activity." ${ }^{136}$ There is a degree of subjectivity in this definition, as the "main object" of a film is open to interpretation, and "explicit sexual activity" is generally not defined. However, we assume, not always correctly, that like American Justice Potter Stewart, we know sex films when we see them. ${ }^{137}$ Adult sex films are sometimes divided into hard core and soft core, though the latter do not show explicit sexual activity. Soft core sexual activity is also referred to as simulated sex, though from a ratings perspective what the performers are actually doing on set is irrelevant. What matters is what is shown in the film.

The MPAA does not classify sex films, and they are produced, distributed, and exhibited separately from other films. However, the boundaries between sex films and other films are porous. Adult sex film performers have cameos in Hollywood films, Hollywood films are parodied in adult sex films, Hollywood makes films about sex films, sex films used the MPAA X rating, Hollywood has co-opted sex film marketing, and sex films may be edited to the point that they can classified by the MPAA and distributed by

\footnotetext{
${ }^{136}$ Ontario Regulation 452/05, s. 1.

${ }^{137}$ Paraphrasing his famous remark, in reference to hard core pornography, "I know it when I see it." The full text illustrates the ongoing challenges courts have faced in determining obscenity. "I have reached the conclusion, which I think is confirmed at least by negative implication in the Court's decisions since Roth and Alberts, that, under the First and Fourteenth Amendments, criminal laws in this area are constitutionally limited to hard core pornography. I shall not today attempt further to define the kinds of material I understand to be embraced within that shorthand description, and perhaps I could never succeed in intelligibly doing so. But I know it when I see it, and the motion picture involved in this case is not that." Jacobellis v. Ohio 378 U.S. 184 (1964). The film in question was Les Amants (Louis Malle, 1958), a French drama of upper class adultery that was perhaps morally transgressive for the time (the woman runs off with her lover) but clearly not an adult sex film.
} 
mainstream distributors. This chapter outlines how sex films became legal in the United States, the associated development of the adult sex feature film, the relationships between sex films and Hollywood, and how these films became legal and subject to classification agency approval in Canada.

\subsection{Early History of Adult Sex Films in the USA}

The early history of sex films is obscured by their illegality. Mainstream films, challenging literature, and materials like birth control pamphlets circulated publically and were targets of moral crusaders. The private exhibition of sex films shielded them from scrutiny and made it easier for (male) authorities to look the other way (or look at them). ${ }^{138}$

Early films seem less explicit than contemporary films, though this is more a result of low grain film stocks, limited lighting, bulky cameras, and body hair, than any effort to hide the action. ${ }^{139}$ The generic imperative of adult sex films is to make visible what is normally hidden, and these films do their best to achieve that. ${ }^{140}$ Sex films remained short, silent, largely devoid of story, and illegal until the 1960s, the only change being the introduction of colour. ${ }^{141}$

\footnotetext{
${ }^{138}$ Williams, Hard Core, 86.

${ }^{139}$ A convenient source of some older films, including A Free Ride, is the nostalgic documentary compilation A History of the Blue Movie, (Alex de Renzy, 1970). Williams notes, in her introduction to Porn Studies, that students in a porn studies class found it much easier to keep a critical distance with early films, due to their markers of age such as hair and clothing styles. Porn Studies, 15.

${ }^{140}$ Williams, Hard Core, 48-49.

${ }^{141}$ Ibid., 60, 96-97.
} 
As noted in chapter three, the Roth decision of 1954 legalized material previously considered obscene. Roth also emphasized that sex was a perfectly legitimate subject for films, stating "sex, a great and mysterious motive force in human life, has indisputably been a subject of absorbing interest to mankind through the ages; it is one of the vital problems of human interest and public concern." ${ }^{142}$ A late 1960s case determined that while selling obscene material was illegal, possessing it was not. ${ }^{143}$ Adult sex films became more or less legal, though exhibition remained private.

\subsection{Development of the Adult Sex Feature}

In the relaxed judicial atmosphere concerning obscenity, and reflecting social changes of the 1960s, some exploitation films became more explicit and less didactic. Respectable venues started showing foreign films with nudity. The dreary Swedish I am Curious (Yellow) (Vilgot Sjömanate, 1967), included visible genitals and non-explicit sex. It was exhibited after lengthy court and customs challenges, as well as the release of an illustrated script, all of which promoted the film. ${ }^{144}$

Along with more daring mainstream films, foreign forays into erotica, and racier exploitation films, a new type of exploitation film appeared: The adult sex documentary. Films such as Sexual Freedom in Denmark (John Lamb, 1970) and History of the Blue Movie used the device of learning about sexuality and sex films to present sex films.

\footnotetext{
142 "Roth v. United States 354 U.S. 476 (1957)."

${ }^{143}$ Stanley v. Georgia 394 U.S. 557 (1969). New laws were eventually created to make illegal possession of sexually explicit material involving children. These laws were not required when possession of any sexually explicit material was illegal.

${ }^{144}$ Wyatt, "The Stigma of X: Adult Cinema and the Institution of the MPAA Ratings System," 245-246.; Lewis, Hollywood v. Hard Core, 158-160.
} 
Sexual Freedom in Denmark included an early appearance of an erect penis in a legal, theatrically exhibited film. ${ }^{145}$

While sex was creeping into legal films, adult sex films continued to be made and privately circulated, but a technological disruption affected the industry. For decades, $16 \mathrm{~mm}$ had been the film of choice for adult sex filmmakers. During the 1960s, the cheaper $8 \mathrm{~mm}$ format became dominant in the home and hobby markets. Existing and new sex films could be converted to $8 \mathrm{~mm}$, but inexpensive $8 \mathrm{~mm}$ cameras were also being used to make new films. As explained by Eric Schaefer in "Gauging a Revolution: 16mm Film and the Rise of the Pornographic Feature," adult sex producers with $16 \mathrm{~mm}$ equipment began looking for new markets.

This led to the rise of storefront theatres, small venues more appropriate to the smaller and darker $16 \mathrm{~mm}$ image than the traditional theatre. The storefront operations were often exempt from theatre licensing due to limited seating, and originally showed non-explicit sex films. The proliferation of these inexpensive theatres, and their competition with the marginally more respectable exploitation theatres (themselves competing with a bolder Hollywood), led to competition in both the explicitness and, more significantly, the narrative appeal of the sexual content. For a one time showing at a stag party, the spectacle of sex was sufficient to entertain, but to keep viewers coming, the storefront theatres had to offer something more than naked bodies doing the same movements, such as character or story. The competition for viewers led some exploitation

\footnotetext{
${ }^{145}$ Williams, Hard Core, 98.
} 
theatres to move away from increasingly explicit and low budget films, while others embraced them. ${ }^{146}$

Decentralized production and distribution of adult sex films makes it difficult to determine when an explicit sexual penetration was first shown as part of a feature film in a public theatre, however Schaefer suggests this was mid-1970 in San Francisco and September 1970 in New York. ${ }^{147}$ By 1972, there were several public releases of narratively driven adult sex feature films, including Deep Throat. The films were low budget by Hollywood standards, but technically competent, thanks to crews that also worked in mainstream films and television. Deep Throat had a common theme for the era: A woman's search for sexual satisfaction, in this case complicated by the woman's clitoris being located in her throat. ${ }^{148}$ The owner of the New York Times Square theatre playing Deep Throat was arrested twice for promoting obscenity, and the resulting trials generated publicity for the film, as did the use of the name Deep Throat by the Watergate informer. The film was eventually banned in many states and cities, but Deep Throat and narrative adult sex films in general had become part of popular culture.

\footnotetext{
${ }^{146}$ Schaefer, "Gauging a Revolution: 16mm Film and the Rise of the Pornographic Feature," 375. Schaefer explains that exploitation theatres did not have the equipment to exhibit $16 \mathrm{~mm}$ films, and some converted to $16 \mathrm{~mm}$, however it is not unusual to shoot in $16 \mathrm{~mm}$ and blow up to $35 \mathrm{~mm}$ for exhibition. Sexual exploitation films without explicit sex did not disappear, and modern equivalents include the Girls Gone Wild series. There are also modern equivalents to the old peep show films of women undressing. Among all the online choices for sex are sites that sell videos of women lounging in revealing clothing, undressing, or performing household activities topless. These are available in both "voyeur" and "caught looking" styles.

${ }^{147}$ Ibid., 388.

148 Though many films were overtly or subtlety misogynist and patriarchal, there was often at least a nominal acknowledgement that female sexual desire existed and there were problems related to female sexual desire and enjoyment.
} 
In 1973, the Supreme Court case Miller v. California reversed the trend of increasingly liberal court decisions and set a new test for determining obscenity. The Miller test, still in force, considers

"(a) whether 'the average person, applying contemporary community' standards would find that the work, taken as a whole, appeals to the prurient interest, ... (b) whether the work depicts or describes, in a patently offensive way, sexual conduct specifically defined by the applicable state law, and (c) whether the work, taken as a whole, lacks serious literary, artistic, political, or scientific value." ${ }^{149}$

A subsequent case established that only explicit sexual activity could be "patently offensive." ${ }^{150}$ By implication, any explicit sexual conduct might be found "patently offensive."

With this stricter though still subjective test for obscenity, and the deference to state law, subsequent successful prosecutions for obscenity led to the closing of many adult theatres and storefront operations. The market for adult sex films shrank to a group of urban centres. ${ }^{151}$ However, the more socially acceptable narrative features, made to appeal to a broad audience, generally escaped prosecution and thrived throughout the 1970s. Part of broad appeal meant being responsive to public criticism. Over the course of the decade, violence against women, such as rape scenarios, became less common. ${ }^{152}$ While some adult film distributors sought the relative legitimacy a self-applied X rating offered, other distributors wanted to distinguish their explicit content from

\footnotetext{
${ }^{149}$ Miller v. California 413 U.S. 15 (1973).

${ }^{150}$ Jenkins v. Georgia 418 U.S. 153 (1974) .

${ }^{151}$ Lewis, Hollywood v. Hard Core, 266.

${ }^{152}$ Williams, Hard Core, 87, 165, 187.
} 
Hollywood erotica, foreign films such as Last Tango in Paris (1972, Bernardo

Bertolucci), exploitation films, and edited adult sex films, all rated X. The invented rating XXX served this purpose.

MPAA members soon wanted to distinguish their non-explicit content from adult sex films rated $\mathrm{X}$. Several films released with an $\mathrm{X}$ rating were edited and re-released as $\mathrm{R}$ rated films, in some cases with new titles. ${ }^{153}$ Midnight Cowboy (John Schlesinger, 1969), originally self-rated X, won the Academy Award for Best Picture in 1970, and received an $\mathrm{R}$ rating from the MPAA in 1971. Films rated $\mathrm{X}$ had significant promotion and exhibition challenges. Some media outlets refused to advertise $\mathrm{X}$ rated films, and many theatres refused to play $\mathrm{X}$ rated films, or could not play them as a condition of lease contracts, particularly in the newly popular mall locations. ${ }^{154}$

On the other hand, Columbia Pictures took advantage of the reputation of the $\mathrm{X}$ rating to promote their American release of Emmanuelle (Just Jaeckin, 1974). The advertising campaign made many references to $\mathrm{X}$, and teased, "X was never like this."155 According to Roger Ebert, the claim was accurate. He noted, "Now that hard-core porno has become passé, it's a relief to see a movie that drops the gynecology and returns to a certain amount of sexy sophistication." ${ }^{156}$

\footnotetext{
${ }^{153}$ Dismal box office performance of some $\mathrm{X}$ rated films from major studios was also a factor. Sandler, The Naked Truth, 49-51.

${ }^{154}$ Lewis, Hollywood v. Hard Core, 285.; Wyatt, "The Stigma of X: Adult Cinema and the Institution of the MPAA Ratings System," 244.

${ }^{155}$ Wyatt, "The Stigma of X: Adult Cinema and the Institution of the MPAA Ratings System," 257-258.

${ }^{156}$ Roger Ebert, "Emmanuelle Movie Review \& Film Summary," January 1, 1975, http://www.rogerebert.com/reviews/emmanuelle-1975.
} 
Sexy sophistication itself quickly became passé. Changing demographics and other factors saw Hollywood lose interest in adult dramas after the early 1970s, and pursue the larger potential audience of PG rated blockbusters such as Jaws (Steven Spielberg, 1975). The MPAA used the X rating three more times in the 1970s, and never again, even when X might have been more appropriate. ${ }^{157}$

\subsection{The Decline of the Adult Sex Feature}

The adult sex film industry was shaken by a new technology in the 1980s: Video tape cassettes. With easy and discreet consumption of adult sex films at home, most of the remaining adult theatres closed. New and existing companies at all quality levels, $35 \mathrm{~mm}, 16 \mathrm{~mm}$, and $8 \mathrm{~mm}$, started shooting on video to cut costs. Superior Video produced features with a budget of $\$ 20,000$, one third the cost of making similar features shot on $35 \mathrm{~mm}$ film. ${ }^{158}$

Without public exhibition to promote films, and greater competition from the lower cost of entry, the profit potential of any single film dropped, and the industry entered a vicious cycle of decreasing quality and increasing quantity. Shooting times dropped to as little as half a day and releases climbed from four hundred in 1983 to over sixteen hundred in $1985 .{ }^{159}$ Private exhibition and competition also eliminated the need to make features that would have broad appeal. Many film makers appealed to specific

\footnotetext{
${ }^{157}$ Sandler discusses how MPAA was widely condemned, even by theatre owners, for giving Cruising (William Friedkin, 1980) an R rating despite content which many felt justified an X. Sandler, The Naked Truth, 63.

${ }^{158}$ David Jennings, Skinflicks: The Inside Story of the X-Rated Video Industry (Bloomington, IN.: Authorhouse, 2000), 165-167.

${ }^{159}$ Ibid., 224-227.
} 
interests and prepared niche films that simply repeated a sexual act or situation. 1970s sex films, once disparaged as crude and low budget, seem artistic and technical masterpieces by comparison.

Paasonen and Saarenmaa are critical of academic and popular histories of adult sex films, such as the film Boogie Nights (Paul Thomas Anderson, 1997), for presenting nostalgic and distorted views of the 1970s sex film industry. Among the distortions they note are an emphasis on a small group of films in the academic histories, on male figures in the popular histories, and themes of loss. They point out that performers in 1970s films are less attractive and less groomed than they are represented as being in more recent films about that period, and that while the number of well-made narrative features decreased after the Golden Age, the rise of home video strengthened the sex film industry and gave it a much larger audience. ${ }^{160}$

Schaefer and others argue that after the Golden Age, adult sex films returned to their previous state of attention to spectacle rather than story. However, relatively well made narrative feature films continue to be produced, and the lower costs of entry allow greater participation of women and sexual minorities as film makers. It should also be acknowledged that even the most narrative adult sex film is still primarily a film of spectacle. ${ }^{161}$

\footnotetext{
${ }^{160}$ Paasonen and Saarenmaa, "The Golden Age of Porn: Nostalgia and History in Cinema," 29. Among the distortions of Boogie Nights is the use of a dedicated crew, which serves as an extended family. While this may have occurred, many Golden Age features were made with crew who also worked on mainstream films and in television production.

${ }^{161}$ Other genres also focus on spectacle. Williams compares sound and narrative strategies in musicals with these aspects of sex films, in the latter case to see how the two genres explore issues of power. Hard Core, $122-183$. The point is made that adult sex features are similar to musicals. Both formats present "numbers" that may depart from the film's realism, may or may not advance the plot, and showcase performers' physical abilities.
} 
The internet has been another technical disruption for the adult sex film industry. With production and distribution costs even lower than home video, there are again more producers competing for viewers, especially paying ones, and there is some evidence that adult sex DVD sales are down. ${ }^{162}$ Watching sexually explicit material online is cheaper and more convenient than buying videos, and has the illusion of greater privacy.

While pornography is thriving online in many forms, the feature length narrative may survive and prosper for the same reasons these films appeared in the early 1970s: They offer more than anonymous gymnastics, broader appeal, and can stand up better to repeat viewings. Unlike the endless collections of explicit sex scenes, the films with narrative appeal are able to differentiate and promote themselves at the new online retailers, which in turn promote more popular films and gather reviews. Film makers can also promote their work with all-ages trailers on YouTube. ${ }^{163}$ It is easy to find ordinary sexual performances online, from bedrooms all over the world, but harder to find well-lit and carefully shot athletic sexual performances by treasure seeking pirates.

\footnotetext{
${ }^{162}$ Classification statistics in Canada suggest a possible decline of adult home video purchases. Adult films classified in BC dropped from 366 in 2011 to 190 in 2013, but the number of stickers, reflecting individual copies, did not decline as significantly. Ontario figures show a significant decline from 2002 (2386) to 2005 (1644), but then a resurgence up to 2786 in 2009. It may only be a coincidence that the number of titles increased after the success of Pirates. Consumer Protection BC, 2011 Annual Report: Administration of the Motion Picture Act, accessed January 19, 2015, http://www.consumerprotectionbc.ca/images/content/publications/2011\%20mpa\%20administration\%20agr eement\%20report\%20-\%20consumer\%20protection\%20bc.pdf. Ontario Film Review Board, Ontario Film Review Board Annual Report 2010/2011, 2011, http://www.ofrb.gov.on.ca/english/Annual\%20Report\%2010-11.pdf.

${ }^{163}$ This is a questionable practice, as it promotes sex film to viewers who may be underage. Advertising a film to an inappropriate audience is also an issue with mainstream films. A common rule among classification agencies, all of which review and classify trailers, is that the rating of a trailer must be the same or lower than the film it is shown with. However, most trailers are edited to have a lower rating than the film they promote, so it is possible to advertise a film to an audience that may not be permitted to attend it.
} 


\subsection{Early History of Adult Sex Films in Canada}

Little is known about the early history of sex films in Canada beyond a few anecdotes. In 1929, a Toronto mansion owner added a small soundproof second floor movie studio, complete with three $35 \mathrm{~mm}$ cameras, and in 1997 the new owners found a hidden cache of "vintage erotica." ${ }^{164}$ The National Archives film collection has two films that are compilations of adult sex films, described as being from 1950 to 1975, however the compilations have never been exhibited and may have been prepared outside the country. ${ }^{165}$ It is likely the early history of sex films in Canada consisted of privately made and discreetly circulated films, as in the United States and other countries.

During the 1960s and 1970s, approved sexual content in mainstream, foreign, and exploitation films increased, but prior restraint prevented more challenging material and explicit sex films from being exhibited. Cuts were usually not challenged. For example, in Ontario I am Curious (Yellow) was simply approved and exhibited with cuts, thus avoiding the publicity of a trial and the legal changes it might bring.

The $16 \mathrm{~mm}$ storefront theatres, a major source of sex films and sex film publicity in the United States, did not arrive in Canada, and possession of all obscene material remained illegal. Even before provincial censors could review them, imported films had to pass through customs, which can seize material without proving it is obscene. $8 \mathrm{~mm}$ sex

\footnotetext{
${ }^{164}$ Deirdre Kelly, "An Old Home Gives up Its Secrets," The Globe and Mail, June 13, 2008, http://www.theglobeandmail.com/life/home-and-garden/real-estate/an-old-home-gives-up-itssecrets/article674376/.

${ }^{165}$ The compilations are copies of films made by aiming an $8 \mathrm{~mm}$ camera at a screen, and named for the first film in each compilation. The $8 \mathrm{~mm}$ footage was developed but never slit, and therefore not ready for projection. The copied films appear to be from the late 1960s and early 1970s, and according to an archives technician, the film stock is from the early 1970s. The source of the compilations is not known. It may be from a film lab that developed the films but was then unsure how to handle the potentially obscene material. The Man Who Came Twice, item 35410; Red Virgin, item 35411. Library and Archives Canada.
} 
films did come into the country, as the National Archives collection indicates, but it is unknown how widely available they were, and there do not appear to be any major court cases involving them.

Although censors themselves might speak out against censorship, as Ontario's Silverthorne did, they were legally required to impose it, and faced the risk of obscenity charges if they were too liberal. One challenging film was Ulysses (1967, Joseph Strick). The film's content and language, particularly a single use of the word fuck, led to bans in several countries. In Ontario, Silverthorne viewed Ulysses with the Crown Attorney, who told him: "Go ahead. Show it. But that doesn't say I won't charge you."166

As in earlier decades, Canadian censors were not immune to the social trends that were liberalizing film content. Until 1967, film censorship in Quebec was one of the strictest in the country. Then, in concert with other changes of the Quiet Revolution, the film censorship process underwent several radical changes. By 1975, Quebec's film censorship was among the most liberal. ${ }^{167}$ This new freedom allowed the rise of a modest soft core sex film industry in Quebec. Variety identified Quebec made soft-core films as Maple Syrup Porn. ${ }^{168}$ Locally they were known by less polite terms such as "films de fesses" ("butt movies"), "films de cul" ("ass movies") or "films cochons" ("pig movies"). ${ }^{169}$

${ }^{166}$ Wise, "History of Ontario's Film Industry, 1896 to $1985, " 6$.

${ }^{167}$ Véronneau, "When Cinema Faces Social Values: One Hundred Years of Film Censorship in Canada."

168 "Canuxploitation! Your Complete Guide to Canadian B-Film."

${ }^{169}$ André Loiselle, "Subtly Subversive or Simply Stupid: Notes on Popular Quebec Cinema," Post Script XVIII, no. 2 (1999): 80-81. Loiselle suggests the terms were not just descriptions of the sexual content, but may have reflected a celebration of the obscene, in the older meaning of materials that are politically subversive. Loiselle notes that while the films took full advantage of liberalized freedom of expression under new censorship guidelines, they often followed the common plot of female sexual liberation within misogynist or patriarchal boundaries. 
British Columbia introduced a completely new Motion Pictures Act in 1970, and among other changes the Chief Censor became the Film Classification Director. ${ }^{170}$ In 1972, Manitoba responded to a series of court cases by switching to a classification only system that does not allow cutting or banning any film. In Ontario, the retiring Silverthorne called for the abolition of censorship, and recommended appointing a young censor to take his place. ${ }^{171} \mathrm{He}$ approved Last Tango in Paris, stating "we just closed our eyes and ears and let it go."172

By the early 1970s, major cities had theatres dedicated to films showing nonexplicit sexual activity, either exploitation films or edits of American explicit sex films. However, in an echo of the Miller decision allowing restrictions on sexually explicit films in the United States, a conservative trend took hold among some Canadian film agencies and other authorities.

The Ontario government criticised their board's "concern for cultivating a reputation for liberality" and called for more censorship, especially of foreign films and of the new medium of videotape. In 1974, the government appointed a retired broadcaster as Chief Censor, who described his role as a "seat belt on your psyche." The following year new legislation brought film festivals, $8 \mathrm{~mm}$ film sales, and peep shows under the jurisdiction of the board. The board approved the violent and sexual exploitation film Ilsa, She Wolf of the SS (Don Edmonds, 1975), but it was seized by Ottawa police. ${ }^{173}$

\footnotetext{
170 "BC Archives: Detailed Finding Aid GR-0490," accessed January 7, 2015, http://royalbcmuseum.bc.ca/bcarchives/.

${ }^{171}$ Dean, Censored!, 148.

${ }^{172}$ Ibid., 141.

${ }^{173}$ Ibid., $147-149$.
} 
Police in British Columbia seized the challenging Japanese erotic film In the Realm of the Senses (Nagisa Ôshima, 1976). ${ }^{174}$ In Quebec, the church led campaigns against locally made non-explicit sex films such as Après-Ski (Roger Cardinal, 1971) and Head or Tails (Roger Fournier, 1971). The publicity helped the industry. ${ }^{175}$

In 1972, Nova Scotia banned Last Tango in Paris, and laid obscenity charges against it. ${ }^{176}$ Provincial court found the film was not obscene, and a journalist then took the board to court, questioning its right to ban films that were not obscene. The matter went to the Supreme Court, and in 1978 that court ruled, in a split decision, that provinces have a right to ban films. In language reminiscent of the United States 1915 Mutual decision, the court noted that provincial film agencies are simply regulating a trade, and not infringing on the federal authority to determine criminal obscenity. ${ }^{177}$ Ontario ordered a two minute cut from the Canadian made and federally funded In Praise of Older Women (George Kaczender, 1978). ${ }^{178}$ The offending scene involved non-explicit sex. The reason for requesting the cut was not provided, but film critic Brian

\footnotetext{
${ }^{174}$ Véronneau, "When Cinema Faces Social Values: One Hundred Years of Film Censorship in Canada," sec. 1427.

${ }^{175}$ Dean, Censored!, 164.

${ }^{176}$ R. v. Odeon Morton Theatres Ltd. and United Artists Corp (1974), 45 D.L.R. (3d) 224. Additional research is required to determine the circumstance that led to the charge. As a general rule, if a film is banned, it is not exhibited, and therefore there are no grounds to lay an obscenity charge. Most cases of films charged with obscenity involve films that have been approved or are not subject to classification.

${ }^{177}$ Nova Scotia Board of Censors v. McNeil, [1978] 2 SCR 662, 1978 CanLII 6 (SCC). The film has since been classified Restricted.

${ }^{178}$ William Marshall, Film Festival Confidential (Toronto: McArthur \& Co, 2005), 20.
} 
Johnson suggests it was because the woman was on top. ${ }^{179}$ Like some adult sex films, part of the promotion for In Praise of Older Women was a three page photo feature in Playboy magazine, offering nude stills and additional photos of the male lead and three of the female performers. ${ }^{180}$

In 1981, organizers of the Canadian Images Film Festival at Trent University were charged and found guilty of screening a film without approval, resulting in "considerable expense to the University." ${ }^{181}$ Frustrated with the actions of the Ontario Board, a small arts organization, Film and Video Against Censorship (later known as Ontario Film and Video Appreciation Society) took the Board to court as soon as the Canadian Charter of Rights and Freedoms was adopted in 1982. The group claimed the Board's restrictions on four films were unconstitutional. ${ }^{182}$

The Ontario Divisional Court ruled that film classification and censorship were justifiable under the new Charter, and that this could include restrictions on the time and place of exhibition, as ordered for two films. The Court also ruled that the Board did not need to classify the third film, Not a Love Story: A Film About Pornography, (Bonnie Sherr Klein, 1981), submitted solely to test the ratings system. The judge noted "the applicants were seeking permission to show a film they did not own and which they had

\footnotetext{
${ }^{179}$ Brian Johnson, Brave Films, Wild Nights: 25 Years of Festival Fever (Random House Canada, 2000), 47.

180 "Observing Older Women," Playboy, October 1978.

${ }^{181}$ A. O. C. Cole, Trent: The Making of a University, 1957-1987 (Peterborough, Ont.: Trent University, 1992), http://www.trentu.ca/library/archives/88-016.htm. Wise, "History of Ontario's Film Industry, 1896 to $1985, " 7$.

182 Wise, "History of Ontario's Film Industry, 1896 to $1985, " 7$.
} 
no right to exhibit." ${ }^{183}$ The Board's refusal to classify the film under these circumstances led to the widely reported ironic myth that the Board banned the film.

The fourth film was the documentary collection Amerika (Al Razutis, 1983), which had been banned. The court ruled that the Board had no legally defined right to ban the film. The government appealed to the Ontario Supreme Court, but the appeal was dismissed in $1984 .^{184}$

The Ontario government had the option of appealing to the Supreme Court of Canada, but instead the government revised and expanded the Theatres Act and associated regulations, so that Board operations, including bans, would be legally defined. At the same time, the regulations and operation of the Board became more open and liberal. The constitutionality of film censorship, and right of provinces to rate, censor, and ban films, has yet to be challenged at the Supreme Court under the Charter of Rights and Freedoms.

\subsection{Acceptance of Adult Sex Films in Canada}

The arrival of home video in the 1980s resulted in a flood of unregulated sex films, explicit and non-explicit, imported and home grown. ${ }^{185}$ Over the course of the decade several provincial governments gave their classification agencies the authority to approve and classify home video, but there was uncertainty over what constituted

\footnotetext{
${ }^{183}$ Re Ontario Film and Video Appreciation Society and Ontario Board of Censors (1983) 41 O.R. (2d) 583 (Ontario High Court 1983).

${ }^{184}$ Re Ontario Film and Video Appreciation Society and Ontario Board of Censors (1984) 45 O.R. (2d) 80 (C.A.) (Supreme Court of Ontario 1984).

${ }^{185}$ Home video was primarily consumed at home, but any adult store could set up a mini theatre with a backroom, a few chairs, a TV, and a VCR. These facilities were similar to the $16 \mathrm{~mm}$ storefront theatres.
} 
obscenity, and it was not unusual for obscenity charges to be laid for films which had been approved.

Just as the United States had many court cases over obscene films in early 1970s, Canada had many court cases over obscene videos in the 1980s. After years of sexual liberation and second wave feminism, the courts were less concerned about sexual explicitness per se. Often at issue was whether or not the situations and acts portrayed were harmful to women. Rulings were not consistent. ${ }^{186}$

The Butler decision provided a lasting national ruling on what constituted obscenity. Donald Victor Butler owned an adult video store in Winnipeg, Manitoba (where no films are banned). In 1987, police seized his inventory and charged him with about 250 counts of selling obscene materials. He was convicted on eight counts, and acquitted of the rest. The Crown appealed, and Butler was convicted on all counts. He appealed to the Supreme Court, arguing that the obscenity provisions of the criminal code violated the Charter of Rights and Freedoms. The Supreme Court determined that the obscenity provisions did violate the charter, but were a reasonable limit. However, the court rejected the convictions of the appeal on the grounds that the films were not obscene.

There are two significant outcomes from Butler. One is the current test for obscenity:

[T] he portrayal of sex coupled with violence will almost always constitute the undue exploitation of sex. Explicit sex which is degrading or dehumanizing may be undue if the risk of harm is substantial. Finally, explicit sex that is not violent and neither degrading nor dehumanizing is

\footnotetext{
${ }^{186}$ Johnson, Undressing the Canadian State, 48-49, 58.
} 
generally tolerated in our society and will not qualify as the undue exploitation of sex unless it employs children in its production. ${ }^{187}$

If the portrayal is determined to be obscene, there is a further test for artistic merit, known as the "internal necessities" test:

The need to apply the "internal necessities" test arises only if a work contains sexually explicit material that by itself would constitute the undue exploitation of sex. The issue then becomes whether this portrayal of sex is the main object of the work or whether it is essential to a wider artistic, literary, or other similar purpose. Artistic expression rests at the heart of freedom of expression values, and Mr. Justice Sopinka felt that any doubt in this regard must be resolved in favour of freedom of expression. ${ }^{188}$

While the American Miller test set the minimum standard for obscenity at being sexually explicit, the Butler test sets a higher standard. There must also be the presence of children, violence, or harm, not justifiable on artistic grounds.

The second significant outcome is the acknowledgement of harm caused by sexually explicit materials, particularly to women. "Harm in this context means that it predisposes persons to act in an anti-social manner as, for example, the physical or mental mistreatment of women by men, or, what is perhaps debatable, the reverse."189 The court was clearly influenced by a submission from the Women's Legal Education and Action Fund, prepared with the assistance of American anti-pornography activist Catherine MacKinnnon. However, Friedman has argued that the Butler tests are patriarchal, balancing male desire against protection of women, and not considering that

\footnotetext{
${ }^{187}$ R. v. Butler [1992] 1 SCR 452.

188 James R. Robertson, Obscenity: The Decision of the Supreme Court of Canada in R. v. Butler. BP-289E. Government of Canada Publications. http://www.publications.gc.ca/Collection-R/LoPBdP/BP/bp289-e.htm Accessed October 14, 2014

${ }^{189}$ R. v. Butler [1992] 1 SCR 452.
} 
women may enjoy violent sexual material. "The unfortunate outcome has therefore been the further suppression of women's sexuality." ${ }^{190}$ Nadine Strossen notes that Butler has been used to justify seizures of gay, lesbian, and feminist materials. ${ }^{191}$

Anti-pornography activists are not happy with Butler either. Subsequent court decisions concerning home and online video ruled that presenting women as sexually insatiable, enjoying men ejaculating into their mouths, or being urinated upon, did not necessarily indicate harm or lack of consent. Johnson claims Butler did not adequately address the issue of harm, and Waltman claims governments in both Canada and the United States prioritize free speech over protecting victims of pornography. ${ }^{192}$

Regardless of the disagreements over Butler, the agencies that reviewed adult sex films had a new test for legal obscenity that they chose to use. The agencies agreed that coercion of any sort was violence. The Baby Sitter \#14 (Jim Powers, 2003) was banned in Ontario because a character appeared to be underage. For MILTF: Mothers I'd Life to Fuck (2002), Ontario requested removal of the dialogue where a "housewife" agrees to purchase magazines from a "student" if he will have sex with her. ${ }^{193}$

\footnotetext{
${ }^{190}$ Friedman, "Working out the Kinks," 105.

191 Strossen, Defending Pornography, 229-244.

192 Johnson, Undressing the Canadian State, 71-73.; Waltman, "Rethinking Democracy," 233-234.

193 Ontario Film Review Board, "Ontario Film Review Board Chair's Files," 2005. In practice, the Board would reject a film, and the distributor had the option of removing footage and resubmitting. The offending portion of Baby Sitter 14 was more than one third if the film, whereas the offending portion of MILTF was only a few minutes. As noted above, many adult sex film releases are compilations of scenes from other films. Both of the offending scenes in these films are available in other films approved in Ontario, as well as in other jurisdictions, revealing inconsistencies in the approval process.
} 


\section{A Second Constitutional Challenge in Ontario}

In 2000, Ontario Theatres Act inspectors purchased the adult sex film Descent at

Glad Day Books. The films had not been approved by the Board, and the seller was

charged with Distributing an Unapproved Film. The store claimed the cost and delay of

getting a film approved was unconstitutional. Glad Day lost, and appealed. ${ }^{194}$

The Ontario Superior Court ruled that mandatory submission for approval was an unconstitutional prior restraint. The ruling did not challenge the validity of the classification system, and gave the government twelve months to separate the classification and censorship functions of the board. ${ }^{195}$ This was widely reported as the end of censorship and putting the Board out of business. ${ }^{196}$

Although the Ontario government eventually replaced the Theatres Act with a new Film Classification Act, little changed. ${ }^{197}$ All films must be classified, continuing the

\footnotetext{
${ }^{194}$ Descent is 123 minutes long, so at $\$ 4.20$ per minute the classification fee would be $\$ 516.60$. For mainstream theatrical releases (with a lower per minute rate), the fees are negligible, but for adult sex home video, particularly for the relatively small queer markets (Descent is an all-male film), the approval fee becomes a significant cost and a barrier to legal distribution. Taryn Sirove, "Freedom, Sex \& Power: Film/Video Regulation in Ontario," Wreck: Graduate Journal of Art History, Visual Art, and Theory 2, no. 1 (2008): 43. The Board approved Descent in 2003, but it is not clear if it was submitted by Glad Day or another distributor.

${ }^{195}$ R. v. Glad Day Bookshops Inc. (C 2004).

${ }^{196}$ A typical article was Tracey Tyler's "Film Board Powers Cut by Ruling on Censorship," Toronto Star, May 1, 2004.

197 Sirove, "Freedom, Sex \& Power," 31. However, there does not appear to be any further appetite for prosecution of unapproved films in Ontario. Unlabeled adult sex films are openly sold in downtown Toronto. Other jurisdictions continue to seize unlabeled adult sex films. In 2009 Nova Scotia took a film distributor to court for selling an unrated sex film, and British Columbia Film Classification seized 40,000 unlabeled DVDs in one 2011 inspection. "Adult-Film Distributor Takes Nova Scotia to Court," The Globe and Mail, November 12, 2009, sec. Arts, http:/www.theglobeandmail.com/arts/adult-film-distributortakes-nova-scotia-to-court/article4196426/.Tatiana, "Why Do We Have 40,000 Adult DVDs in Our Office?," Consumer Protection BC, accessed January 17, 2015, http://www.consumerprotectionbc.ca/component/k2/item/45-adult_dvd_seizure.
} 
prior restraint found unconstitutional, and while no mainstream film can be banned, the government reserved the right to ban any adult sex film.

\subsection{Conclusion}

The move to more liberal film censorship and classification in the Canada and the United States has been like the race between the tortoise and the hare. Both countries started at the same place, with similar laws and approaches to censorship. The strength of the industry in the United States allowed it to set up its own censorship for major films, and court challenges allowed sooner legalization of adult sex films. Canada's prior restraint for all films, age restrictions, and government enforcement were much more restrictive. As mainstream films incorporated more challenging subjects and society became more tolerant of this content, Canada's use of age ratings meant provincial agencies were more able to adapt to approving mature content than the MPAA. Once home video forced the issue of obscenity law development in Canada, the resulting regulations gave adult sex films a legitimacy and influence in ratings systems that they have not achieved in the United States. Some adult sex films are still subject to prior restraint, but Canada's obscenity law provides clearer guidelines than American law. 


\section{Structure and Operation of the Agencies}

This chapter outlines the current structure, operations, and classifications of the MPAA in the United States and the provincial agencies in Canada: Nova Scotia, Quebec, Ontario, Manitoba, Alberta, and British Columbia.

\subsection{MPAA Structure}

The Classification and Ratings Administration (CARA) is nominally an independent organization, however the Chair is appointed by the MPAA in consultation with the National Association of Theatre Owners (NATO). ${ }^{198}$ The Chair selects raters "who represent the diversity of American parents," who must be parents of children between five and fifteen at the time of appointment, and who are not involved in the entertainment industry. Raters serve for up to seven years, at the discretion of the Chair. From the Raters, the chair selects Senior Raters, who lead deliberations. There are no term limits on Senior Raters. The identities of Raters are kept secret, apparently to protect them from being pressured by film makers or the public, but the identities of Senior Raters are public. ${ }^{199}$

CARA maintains a separate Appeals Board, which is essentially the film industry. The board consists of representatives appointed by MPAA and NATO, representatives appointed by members of the Independent Film and Television Producers Alliance who

\footnotetext{
198 The International Film Importers and Distributors of America, representing several smaller studios, was also initially associated with CARA, but that organization shut down in 1978.

${ }^{199}$ Motion Picture Association of America, Inc. and National Association of Theatre Owners, Inc., "Classification and Rating Rules," January 1, 2010, http:/www.filmratings.com/what.html. The MPAA has a reputation for secrecy, however the Ratings Rules have been available online for several years. Posting them, and the creation of the Senior Rater position, may have been in response to concerns about the organization raised by Kirby Dick in This Film Is Not Yet Rated.
} 
have agreed to submit all their films to CARA, and representatives not associated with the film industry, who are appointed by the MPAA and NATO. A quorum of the Appeals Board is nine members, with three from the MPAA and three from NATO. ${ }^{200}$ Given the power of the MPAA appointed Chair, and the structure of the Appeals Board, claims of CARA independence are highly suspect.

The ratings system is funded by fees charged to MPAA members, based in part on their gross income. All members of the MPAA must submit their films for ratings and use those ratings when exhibiting the film. Non-members of the MPAA may submit their films, but can choose to exhibit a film as unrated even after obtaining a rating.

Enforcement of CARA classifications is handled by theatres, most of which are members of NATO. ${ }^{201}$ MPAA ratings can also be used for home video releases. ${ }^{202}$

\subsection{MPAA Ratings}

The MPAA has five classifications, based on consideration of the following elements: theme, language, violence, nudity, sensuality, sexual activity, adult activities, and drug use. The nature of the theme, and the presence and amount of other elements,

\footnotetext{
${ }^{200}$ Motion Picture Association of America, Inc. and National Association of Theatre Owners, Inc., "Ratings Rules."

${ }^{201}$ Sandler, The Naked Truth, 53-55. Independent theatres are free to ignore the ratings. For example, Blue is the Warmest Color (Abdellatif Kechiche, 2013) was rated NC-17, not allowing admission to anyone under 18, however at least one theatre owner felt it was appropriate for "high school age" viewers. A. O. Scott, "Theater Will Ignore NC-17 Rating for 'Blue Is the Warmest Color,"' ArtsBeat, accessed January 21, 2015, http://artsbeat.blogs.nytimes.com/2013/10/23/theater-will-ignore-nc-17-rating-for-blue-is-thewarmest-color/.

${ }^{202}$ Motion Picture Association of America, Inc. and National Association of Theatre Owners, Inc., "Ratings Rules."
} 
determines the rating. Since 1990, the rating information includes a brief description of the content responsible for the classification. ${ }^{203}$

CARA uses surveys and focus groups to validate the classification process, and claims ratings evolve as parents' sensibilities do. ${ }^{204}$ This evolution is the ratings creep noted by several researchers. ${ }^{205}$

The classifications are:

- G - General Audiences. All Ages Admitted. Violence is minimal, and there is no nudity, sexual activity, or drug use. ${ }^{206}$

- PG - Parental Guidance Suggested. Some material may not be suitable for children. This classification was originally $\mathrm{M}$, then GP, and finally PG in 1972.

- PG-13 - Parents Strongly Cautioned. Some material may be inappropriate for children under 13

- $\mathrm{R}$ - Restricted. Children under seventeen require accompanying parent or adult guardian. Restricted films "contain some adult material" and are not appropriate for young children. From 1968 to 1970 the age restriction applied to children under sixteen.

- NC-17. No one seventeen and under admitted. The NC-17 classification was known X until 1990, and could be self-applied. From 1968 to 1970 the age restriction applied to children under sixteen.

The PG-13 category was introduced in 1984, to provide a classification between

PG and R, however it does not have an age restriction. Compared to PG, the PG-13 rating contains more of each of the elements. More than one "harsher sexually-derived word" in a non-sexual context, or even just one use in a sexual context, is an automatic $\mathrm{R}$ rating,

203 "Why: History of Ratings," filmRatings.com The Classification \& Ratings Administration, accessed January 19, 2015, http://www.filmratings.com/.

${ }^{204}$ Ibid.

${ }^{205}$ Thompson and Yokota, "Violence, Sex, and Profanity in Films." Leone and Houle, "21st Century Ratings Creep."; Leone and Barowski, "MPAA Ratings Creep.";

${ }^{206}$ For the classification descriptions, current information is from the Ratings Rules and changes since 1968 are from Tropiano. Motion Picture Association of America, Inc. and National Association of Theatre Owners, Inc., "Ratings Rules." Obscene, Indecent, Immoral \& Offensive, 92-93. See table 2 for additional details about the classifications for all jurisdictions. 
unless a two-thirds majority of the board votes that a PG-13 rating would still be appropriate.

All the classifications stress the goal of providing information about what might offend parents of young children, and all classifications except NC-17 leave the decision about viewing a specific film to the parents (strictly speaking, one parent or a guardian). This approach has been criticized as placing too much emphasis on what is offensive to parents rather than what is harmful to children. ${ }^{207}$ Implicit in this approach is that adults can watch anything, and ratings are only for children.

The ratings categories and information about the process are explained on the CARA web site, and there is a searchable database of film ratings that dates back to 1968 . CARA offers a weekly subscription email of ratings for new and recently released films, which is also posted to twitter.

\subsection{Provincial Agency Structures}

Canada is a rare example of censorship at the state or provincial level. Of the twenty-two countries discussed by Jeffrey Brand in "A Comparative Analysis of Ratings, Classification and Censorship in Selected Countries around the World," Canada is the only one without a national film censorship organization. Switzerland did have five commissions establishing ratings for the twenty-six cantons, each of which could override the commission rating, but since 2011 has moved to a national system. ${ }^{208} \mathrm{~A}$

\footnotetext{
207 Wilson, Linz, and Randall, "Applying Social Science Research to Film Ratings."

208 Thomas Stephens, "Film Commission Aims to Clear up Royal Mess," SWI Swissinfo.ch, February 28, 2011, http://www.swissinfo.ch/eng/film-commission-aims-to-clear-up-royal-mess/29606612.
} 
national system is unlikely to emerge in Canada, though there may be further sharing like the BC and Saskatchewan agreement. Lee's 2003 report noted that a national system would pose "insurmountable problems for local film makers, festivals and societies."209

The currently active agencies are in Nova Scotia, Quebec, Ontario, Manitoba, Saskatchewan, Alberta, and British Columbia. ${ }^{210}$ New Brunswick closed its agency in 1994, and began using the classifications from Nova Scotia for English language films, and from Quebec for French language films. ${ }^{211}$ Prince Edward Island, which previously had no film classification, also began using the Nova Scotia ratings in 1994, and since then the Nova Scotia rating has also been referred to as the Maritime Film Classification. ${ }^{212}$ In 1997, Saskatchewan began using the ratings from British Columbia for mainstream films. There is still a Saskatchewan film classification agency, but its activity is limited to documenting classifications for festival and other local showings. ${ }^{213}$ Table 1 outlines the jurisdictions of the agencies.

The provincial agencies operate under various ministries or departments of their government and, with the exception of British Columbia, the agencies answer to an elected official. Since 2007, film classification in British Columbia has been performed

\footnotetext{
${ }^{209}$ Lee, Research on Community Standards., 36.

${ }^{210}$ Except as noted, the information in this chapter about the agencies structures and ratings is from their web sites, Acts, or Regulations.

211 Government of New Brunswick," Film Exchange Licence," 11:08:36.0, http://www2.gnb.ca/content/gnb/en/services/services_renderer.835.Film_Exchange_Licence.html.

212 Government of Prince Edward Island, "Film Classification," Prince Edward Island: Department of Environment, Labour and Justice, accessed January 19, 2015, http://www.gov.pe.ca/jps/index.php3?number=20822\&lang=E.

${ }^{213}$ Government of Saskatchewan, "Film and Video Classification Board," Ministry of Justice - Branches, Boards and Commissions, accessed January 19, 2015, http://www.justice.gov.sk.ca/filmandvideoclassification.
} 
by Consumer Protection BC, a non-profit corporation that regulates businesses. For each agency, there is a publicly available act and associated regulations outlining the powers, duties, and operations of the agency.

Nova Scotia, Ontario, and Manitoba have film review boards composed of members of the public, typically working three or four days a month. The intention is to have a diverse cross section of the public represented, however part time boards self-limit themselves to people who seek out government board positions and who are available to work a few weekdays a month, such as retirees and the self-employed.

Appeals in Nova Scotia are addressed by the Utility and Review Board, under a different ministry. Appeals in Ontario are handled by different members of the board, and appeals in Manitoba are handled by a separate board under the same ministry.

British Columbia, Quebec, and Alberta have full time staff to classify films. In British Columbia appeals are handled by the Director of the agency, and in Quebec appeals are addressed by the Tribunal administratif du Québec. In Alberta, appeals of the staff decisions are handled by a public board, making this the only province to use both a public board and government employees as classifiers. Compositions of the agencies are summarized in Table 1.

All of the agencies charge fees for classifying films. Most agencies charge between two and four dollars per minute of film or video, and there can be additional fees for multiple prints, previews to determine elimination requirements, adult sex films, and labels.

The jurisdictions that approve home video require approved films to be labelled with the classification before sale or rental. Some labels simply state the name of the 
agency and the rating, while others are specific to the film. British Columbia requires each copy of an approved adult sex home video tape or DVD to have a uniquely numbered label. These hard to duplicate labels cost distributors two dollars each. Adult film distributors have supported this expense, as the individual labelling and numbering of copies helps prevent piracy. Appendix A shows the labels on a mainstream film sold in Quebec. There is a label on the disc and on the package, as required. In addition, the distributor has printed the classification for Quebec on the package.

Quebec has lower fees for Quebec films and French films dubbed in Quebec, and Ontario does not charge to classify mainstream films made in Canada. Some agencies classify films at no cost for film festivals or charities. Every agency has a list of film types that are exempt from classification. The agencies claim fees are to cover the cost of operations, but according to the latest available report of the Ontario Film Review Board (2010-2011), the board collected $\$ 2,634,690$ in fees and had $\$ 1,015,287$ in expenses. ${ }^{214}$ Detailed financial information is not available for the other agencies.

Theatrical films must be classified by law in all provinces and territories except Newfoundland and Labrador, and the Yukon. Those jurisdictions, as well as Saskatchewan and Alberta, do not require classification for home video. British Columbia does not require classification for home video, except adult films. These are largely but not exclusively sex films and home video. ${ }^{215}$ Manitoba, Ontario, Quebec, and

${ }^{214}$ Ontario Film Review Board Annual Report 2010/2011.

${ }^{215}$ For example, Irreversible is not classified as a sex film, but it is adults only and therefore must be classified and labelled for home video distribution. There are several locations in Vancouver that offer private viewing booths or mini-theatres for adult sex films, including one facility that still uses $8 \mathrm{~mm}$ loop projectors. Even if they are showing DVDs on a TV screen, a viewing booth is legally considered a theatre (with a seating capacity of one) and licensed accordingly. 
the Maritimes all require classification of home video. This leaves Alberta as the only agency that classifies theatrical releases exclusively, and therefore similar to the MPAA in terms of the material classifiers view. The scopes of the agencies are summarized in Table 1.

The expansion of the agencies' authority over home video, starting in the $1980 \mathrm{~s}$, was a concern for distributors unhappy about the prospect of different labels and ratings for every province. To resolve this, the Motion Picture Association of Canada (MPACanada) and the English language agencies collaborated to create the Canadian Home Video Ratings System (CHVRS). ${ }^{216}$ The agencies submit their theatrical ratings to MPACanada, and the CHRVS rating is calculated from those. Ontario and Manitoba allow home video labelling with the provincial classification and label, or the CHRVS classification and label, even if they differ. The Maritimes still requires their own label, and Quebec does not participate in the CHVRS. A CHRVS classification can be seen on the packaging shown in Appendix A. Adult sex films are not included in the CHVRS.

Home video and the CHVRS also encouraged the English language agencies to harmonize their classification names and symbols, though there are minor differences in the classifications. Since 2004, all English language agencies and the CHVRS have used the same five levels and symbols for mainstream films.

\footnotetext{
216 Strictly speaking, CHRVS is operated by the Motion Picture Classification Corporation of Canada (MPCCC), but the public face of CHVRS (and business address of the MPCCC) is MPA-Canada.
} 


\subsection{Provincial Ratings}

The classifications for the English language agencies are General (G), Parental Guidance (PG), 14A, 18A, and Restricted (R). The A indicates that adult accompaniment is required. There are some similarities to the MPAA. General and Parental Guidance are essentially the same. Restricted is equivalent to $\mathrm{NC}-17$, and 18A is similar to the MPAA's Restricted, though with a one year age difference. 14A and PG-13 are significantly different: The former is an age restriction, while the latter is simply an advisory. Both were introduced in the 1980s, and 14A was previously called AA (Adult Accompaniment) in some jurisdictions. Manitoba has a classification and labels to identify films that are exempt from classification.

The meanings of the classifications vary slightly, and there is one difference in the age restrictions. The $18 \mathrm{~A}$ classification, no one under eighteen unless accompanied by an adult, also prohibits anyone under 14 in the Maritimes and Manitoba. In Ontario, Saskatchewan, Alberta, and British Columbia, a child of any age can view an 18A film if accompanied by an adult.

Quebec has four levels of classification: General, $13+, 16+$, and $18+$. There is no equivalent to the PG used in other jurisdictions. 13+, which requires adult accompaniment for anyone under 13, is similar to 14A. Quebec's 18+ is equivalent to other provinces' Restricted: No one under 18 is admitted. Quebec does not have an equivalent to the $18 \mathrm{~A}$ rating used in other provinces, but it does have the additional $16+$ rating, not admitting anyone under 16 . The ratings for the provincial agencies are summarised in Table 2. 
For regulatory purposes, the provinces that approve adult sex films may consider them as completely separate from other films, as an additional classification, or as a specific type of Restricted film. Regardless of the difference, they are all limited to ages 18 and up, and have additional restrictions on display and advertising.

Classifications in all provinces may include additional information, generally known as Content Advisories, which either provide information about what led to the classification, or additional information about a film's content. Examples of the latter include "Not Suitable for Children" on a G rated film, to note that while there is no potentially offensive material in the film, it is not intended for children to view, and "Sexual Violence" on a Restricted film, to note that there is a portrayal of non-consensual sex or sexual degradation. All the agencies except British Columbia have a set list of advisories.

Like the MPAA, the eastern and central Canadian agencies stress consideration of elements when determining classifications. The Nova Scotia regulation notes the classification must consider the "general character of film," as well as the elements of language, violence, nudity, sexual activity, and frightening scenes, and the maturity required for the psychological or emotional impact of the film. Quebec considers the elements of violence, sexuality, controversial issues, attacks on individuals, and psychological impact, taking into account the overall tone, context, and realism.

Ontario considers language, violence, nudity, sexual activity, horror, and psychological Impact. The Board's internal guideline documents provide details of how to consider each element, and examples depending on the classification. ${ }^{217}$ A shorter

${ }^{217}$ Ontario Film Review Board, "Classifying Mainstream Films," 2007. 
version is available on the Board's web site and is attached as Appendix B. Reviewers can assign a lower rating than the element guidelines would otherwise allow, if they consider the film to have documentary or historical value. This is a more limited and specific approach to considering the film as a whole, or the overall tone, as done in Nova Scotia and Quebec. The documentary and historical exemption was a factor in determining the ratings for Saving Private Ryan (Steven Spielberg, 1998) and The Passion of the Christ (Mel Gibson, 2004). ${ }^{218}$

The western agencies downplay attention to escalating quantities of elements in favour of considering that certain age classifications are appropriate for certain content. For example, in Manitoba the regulation notes that 14A is for "lifestyles," "social roles," imagery, or language that some may find offensive. The 18A classification is for films that might contain frequent coarse language, sexually suggestive activity, some nudity, violence but not extreme gratuitous violence, or substance abuse but not promotion of substance abuse. Alberta considers the amount and detail of "potentially controversial material," in context of each film's "overall theme and intent." 219

British Columbia has no set guidelines for classification, and unlike Ontario, where checklists are used to track elements, classifiers work with a blank sheet of paper. ${ }^{220}$ Language and sexually suggestive scenes may be in $14 \mathrm{~A}$ films, while Restricted films may have explicit sex, or violence, but are "artistic, historical, political, educational

\footnotetext{
${ }^{218}$ Personal communication with a member of the Board, September, 2005.

${ }^{219}$ Government of Alberta, "Alberta Film Ratings."

${ }^{220}$ Personal communication with a member of the Board, July, 2014.
} 
or scientific." Adult pictures might have realistic or explicit sex or brutality, but "the scenes would, in the [agency] director's opinion, be tolerable to the community."221

The end result of classifying by working up from the elements, or working down from the classifications, is similar. Tracking elements is beneficial as a way to objectively document and justify a classification. In some cases it can be rigid. For example, with regard to the MPAA's "harsher sexually-derived word," Ontario guidelines permit it an average of once every thirty minutes in a PG film. ${ }^{222}$ With this rule, knowing whether there are three or four fucks in an 88 minute film can be important in determining the rating. The content advisories for some films rated in British Columbia reveal that classifiers there are counting swear words, despite a blank sheet and no guidelines. Even with objective elements, there remain subjective considerations, such as psychological impact.

All of the provincial agencies are easy to contact through their websites, and they encourage feedback on the ratings. As government agencies, they also receive feedback from elected representatives, and, at least in the case of Ontario, have had their operations discussed in the provincial parliament as a result of concerns and petitions from constituents. Ontario and Quebec occasionally have presentations from experts in child development, and about ten years ago, British Columbia commissioned a report on Community Standards. ${ }^{223}$ The agencies also exchange information with each other and meet with industry representatives.

\footnotetext{
${ }^{221}$ Consumer Protection BC, "Motion Pictures."

${ }^{222}$ Ontario Film Review Board, "Classifying Mainstream Films," 8.

${ }^{223}$ Lee, Research on Community Standards.
} 
Ontario is exceptionally open to public participation. Members of the public can attend screening sessions by appointment, and there are regular public evening sessions. At these sessions, open to anyone over eighteen, members of the public and a Board panel view an unreleased film. Each group independently rates it, and they compare results and discuss the classification. The discussion aids the public in understanding the process, and Board members in understanding public concerns and perceptions.

The film industry may not be comfortable with public screenings. No other agency offers them, and several provinces prohibit non-staff or non-board members from attending classification sessions. In British Columbia, at the request of film distributors, a security guard is present at all screenings to prevent copying. ${ }^{224}$

All the agencies provide information about the classification process and ratings for films on their web sites, and every agency except Nova Scotia supplies additional details such more content advisories, a synopsis, and plot themes. Quebec uses Facebook to announce classifications, and to promote film festivals and lesser known films. Alberta offers a weekly email of ratings decisions, and $\mathrm{BC}$ and Alberta use twitter to announce film classifications.

Ontario posts Reconsideration Decisions on their site. These are the outcomes of Appeals, but they do not indicate if the classification has gone up or down, and as a general rule all agency sites only show the current classification. Older films may have a note indicating a previous classification and reclassification date. There is no indication if films have been cut for classification, which is irrelevant for most but not all current

\footnotetext{
${ }^{224}$ Personal communication with a member of the Board, July, 2014.
} 
releases. Most of the web sites list approved films dating back to the 1920s or 1930s. British Columbia only lists classifications for films released or re-released after the mid1970 s, though there is a note suggesting contacting the agency for information about older films. The agencies are shy about Adult Sex Film classification information on their sites. British Columbia and Manitoba mention that sex films require approval, but do not provide any information about specific films. Approved sex films are listed on the sites for Ontario, Quebec, and Nova Scotia, but at least one extra step is required to view them, and there are no advisories or other information about the content of the approved films.

\subsection{Conclusion}

The MPAA claims to represents the interests of parents with the ratings system, but the structure and operation of the agency ensures the interests of the major studios are dominant. This may partly explain the support for several alternate agencies that also claim to represent the interests of parents. The five levels of classification are consistent with systems in other countries, but the lack of an enforced mid-teen classification leaves a gap and makes the PG and PG-13 ratings perhaps too similar to be useful. The limited use of the adults only $\mathrm{NC}-17$ classification is understandable as the ratings are voluntary, and many films which might be NC-17 are simply distributed unrated. As the MPAA does not classify independent, foreign, or sex films, the reviewers are not exposed to the full range of films available to the public.

The Canadian classification agencies are structured and operated in different ways. Most of the agencies classify all films available, including adult sex films, but 
Alberta reviewers see the almost the same group of films as the MPAA classifiers. British Columbia classifiers do not review straight to video DVDs, but still see adult films.

The following chapters compare a set of films, and examine three specific films, to identify differences in the ratings systems, and determine if there are relationships between the structure and operation of the agencies and the differences in the ratings systems. 
Table 1 - Agency Jurisdictions and Structures

\begin{tabular}{|c|c|c|c|c|c|}
\hline Name & Government Area & Jurisdiction & Home video? & $\begin{array}{l}\text { Classification } \\
\text { Panel } \\
\end{array}$ & Appeal Panel \\
\hline $\begin{array}{l}\text { Nova Scotia Film and Video } \\
\text { Classification }\end{array}$ & Service Nova Scotia & $\begin{array}{l}\text { Prince Edward Island } \\
\text { Nova Scotia } \\
\text { New Brunswick (English } \\
\text { language films) } \\
\text { Newfoundland* }\end{array}$ & Yes & Public board & $\begin{array}{l}\text { Utilities and Review } \\
\text { Board (Public board) }\end{array}$ \\
\hline Régie du cinéma & Ministère de la Culture et des Communications & $\begin{array}{l}\text { Quebec } \\
\text { New Brunswick (French } \\
\text { language films) }\end{array}$ & Yes & Employees & $\begin{array}{l}\text { Tribunal administratif } \\
\text { du Québec }\end{array}$ \\
\hline Ontario Film Review Board & $\begin{array}{l}\text { Ministry of Government and Consumer } \\
\text { Services }\end{array}$ & Ontario & Yes & Public board & \\
\hline $\begin{array}{l}\text { Manitoba Film Classification } \\
\text { Board }\end{array}$ & $\begin{array}{l}\text { Manitoba Tourism, Culture, Heritage, Sport } \\
\text { and Consumer Protection }\end{array}$ & Manitoba & Yes & Public board & Public board \\
\hline $\begin{array}{l}\text { Saskatchewan Film and } \\
\text { Video Classification Board }\end{array}$ & Ministry of Justice & Saskatchewan** & $\begin{array}{l}\text { No, except Adult } \\
\text { Sex films }\end{array}$ & Employees & \\
\hline Alberta Film Classification & Ministry of Culture. & $\begin{array}{l}\text { Alberta } \\
\text { Northwest Territories } * * * \\
\text { Nunavut } * * *\end{array}$ & No & Employees & Public board \\
\hline BC Film Classification & $\begin{array}{l}\text { Consumer Protection BC (non-profit } \\
\text { corporation), by agreement with the Ministry of } \\
\text { Justice }\end{array}$ & $\begin{array}{l}\text { British Columbia } \\
\text { Saskatchewan } \\
\text { Yukon* }\end{array}$ & $\begin{array}{l}\text { No, except Adult } \\
\text { sex and Restricted }\end{array}$ & Employees & Director \\
\hline
\end{tabular}

* Classification is not required, but theatres typically use it.

** Most films are classified by British Columbia. If a BC rating is not available, uses ratings from another province, the MPAA, the British Board of Film Classification, or the Canadian Home Video Ratings System.

*** Typically uses Alberta ratings, but can use ratings of another province. 
Table 2 - Ratings Summary

\begin{tabular}{|c|c|c|c|c|c|c|}
\hline Board & G & $\begin{array}{l}\text { PG } \\
\text { Parental guidance is } \\
\text { advised }\end{array}$ & $\begin{array}{l}\text { 14A } \\
\text { No admission } \\
\text { under } 14 \text { unless } \\
\text { accompanied by } \\
\text { an adult. }\end{array}$ & $\begin{array}{l}\mathbf{1 8 A} \\
\text { No admission under } 18 \\
\text { unless accompanied by } \\
\text { an adult. }\end{array}$ & $\begin{array}{l}\text { Restricted } \\
\text { No admission under } 18\end{array}$ & $\begin{array}{l}\text { Adult } \\
\text { No admission under } 18 .\end{array}$ \\
\hline $\begin{array}{l}\text { Nova Scotia } \\
\text { Film and Video } \\
\text { Classification }\end{array}$ & All ages & $\begin{array}{l}\text { "Theme or content } \\
\text { may not be suitable } \\
\text { for all children." }\end{array}$ & $\begin{array}{l}\text { "May contain: } \\
\text { violence, coarse } \\
\text { language and/or } \\
\text { sexually } \\
\text { suggestive } \\
\text { scenes." }\end{array}$ & $\begin{array}{l}\text { No admission under } \\
14 . \\
\text { "May contain: explicit } \\
\text { violence, frequent } \\
\text { coarse language, } \\
\text { sexual activity and/or } \\
\text { horror." }\end{array}$ & $\begin{array}{l}\text { "Contains frequent use } \\
\text { of sexual activity, } \\
\text { brutal/graphic } \\
\text { violence, intense } \\
\text { horror and/or other } \\
\text { disturbing content." }\end{array}$ & $\begin{array}{l}\text { "Film is not suitable for } \\
\text { viewers under } 18 \text { years of } \\
\text { age because the sole or } \\
\text { primary premise for the film } \\
\text { is the depiction of explicit } \\
\text { sexual activity, graphic } \\
\text { nudity, or graphic violence." }\end{array}$ \\
\hline $\begin{array}{l}\text { Ontario Film } \\
\text { Review Board } \\
\text { (See Appendix B } \\
\text { for additional } \\
\text { details and } \\
\text { examples by } \\
\text { element) }\end{array}$ & All ages. & $\begin{array}{l}\text { "Theme or content } \\
\text { may not be suitable } \\
\text { for all children." }\end{array}$ & $\begin{array}{l}\text { "May contain: } \\
\text { violence, coarse } \\
\text { language and/or } \\
\text { sexually } \\
\text { suggestive } \\
\text { scenes." }\end{array}$ & $\begin{array}{l}\text { "May contain: explicit } \\
\text { violence, frequent } \\
\text { coarse language, } \\
\text { sexual activity and/or } \\
\text { horror." }\end{array}$ & $\begin{array}{l}\text { "May contain: frequent } \\
\text { use of sexual activity, } \\
\text { brutal/graphic } \\
\text { violence, intense } \\
\text { horror and/or other } \\
\text { disturbing content." }\end{array}$ & $\begin{array}{l}\text { A "film that has, as its main } \\
\text { object, the depiction of } \\
\text { explicit sexual activity." }\end{array}$ \\
\hline $\begin{array}{l}\text { Manitoba Film } \\
\text { Classification } \\
\text { Board }\end{array}$ & $\begin{array}{l}\text { "Suitable for those } \\
\text { under 12." }\end{array}$ & $\begin{array}{l}\text { "Most suitable for } \\
\text { mature viewers over } \\
\text { 12." }\end{array}$ & $\begin{array}{l}\text { "Subject matter or } \\
\text { language may be } \\
\text { controversial or } \\
\text { offensive." }\end{array}$ & $\begin{array}{l}\text { No admission under } \\
\text { 14. "Will likely } \\
\text { contain explicit } \\
\text { violence, frequent } \\
\text { coarse language, } \\
\text { sexual activity and/or } \\
\text { horror." }\end{array}$ & $\begin{array}{l}\text { "May contain many } \\
\text { scenes of horror, } \\
\text { violence, sexual } \\
\text { activity or material that } \\
\text { degrades individuals or } \\
\text { groups." }\end{array}$ & $\begin{array}{l}\text { A film where "the sole or } \\
\text { primary premise for the film } \\
\text { is the depiction of explicit } \\
\text { sexual activity [or] graphic } \\
\text { violence." }\end{array}$ \\
\hline
\end{tabular}




\begin{tabular}{|c|c|c|c|c|c|c|}
\hline Board & $\mathbf{G}$ & $\begin{array}{l}\text { PG } \\
\text { Parental guidance is } \\
\text { advised }\end{array}$ & $\begin{array}{l}\text { 14A } \\
\text { No admission } \\
\text { under } 14 \text { unless } \\
\text { accompanied by } \\
\text { an adult. }\end{array}$ & $\begin{array}{l}\mathbf{1 8 A} \\
\text { No admission under } 18 \\
\text { unless accompanied by } \\
\text { an adult. }\end{array}$ & $\begin{array}{l}\text { Restricted } \\
\text { No admission under } 18\end{array}$ & $\begin{array}{l}\text { Adult } \\
\text { No admission under } 18 .\end{array}$ \\
\hline $\begin{array}{l}\text { Alberta Film } \\
\text { Classification }\end{array}$ & All ages & $\begin{array}{l}\text { "Theme or content } \\
\text { may not be suitable } \\
\text { for all children." }\end{array}$ & $\begin{array}{l}\text { "May contain } \\
\text { violence, coarse } \\
\text { language, and/or } \\
\text { sexually } \\
\text { suggestive } \\
\text { scenes." } \\
\end{array}$ & $\begin{array}{l}\text { "May contain explicit } \\
\text { violence, frequent } \\
\text { coarse language, } \\
\text { sexual activity and/or } \\
\text { horror." }\end{array}$ & $\begin{array}{l}\text { "Contains frequent } \\
\text { sexual activity, } \\
\text { brutal/graphic } \\
\text { violence, intense } \\
\text { horror and/or other } \\
\text { disturbing content." }\end{array}$ & $\mathrm{N} / \mathrm{A}$ \\
\hline $\begin{array}{l}\text { BC Film } \\
\text { Classification }\end{array}$ & $\begin{array}{l}\text { All ages } \\
\text { "Occasional } \\
\text { violence, swearing } \\
\text { and coarse language, } \\
\text { and the most } \\
\text { innocent of sexually } \\
\text { suggestive scenes } \\
\text { and nudity, are } \\
\text { permitted in this } \\
\text { category." }\end{array}$ & $\begin{array}{l}\text { "...may contain less } \\
\text { subtle sexually } \\
\text { suggestive scenes } \\
\text { and nudity and a } \\
\text { more realistic } \\
\text { portrayal of violence } \\
\text {... coarse language } \\
\text { may occur more } \\
\text { often than in the } \\
\text { General category. }\end{array}$ & $\begin{array}{l}\text { "... may contain } \\
\text { violence, coarse } \\
\text { language or } \\
\text { sexually } \\
\text { suggestive scenes, } \\
\text { or any } \\
\text { combination of } \\
\text { them." }\end{array}$ & $\begin{array}{l}\text { "...will contain horror, } \\
\text { explicit violence, } \\
\text { frequent coarse } \\
\text { language or scenes that } \\
\text { are more sexually } \\
\text { suggestive than in the } \\
\text { 14A category, or any } \\
\text { combination of them." }\end{array}$ & $\begin{array}{l}\text { "...may contain explicit } \\
\text { sexual scenes, } \\
\text { violence..." } \\
\text { Category used if the } \\
\text { "theme, subject matter } \\
\text { or plot of the adult } \\
\text { motion picture is } \\
\text { artistic, historical, } \\
\text { political, educational } \\
\text { or scientific." Uses the } \\
\text { Cougar logo. }\end{array}$ & $\begin{array}{l}\text { "...may contain explicit } \\
\text { sexual scenes or scenes of } \\
\text { brutality or torture to persons } \\
\text { or animals, or any } \\
\text { combination of them, that } \\
\text { are portrayed in a realistic } \\
\text { and explicit manner; } \\
\text { however, the scenes would, } \\
\text { in the director's opinion, be } \\
\text { tolerable to the community." }\end{array}$ \\
\hline
\end{tabular}




\begin{tabular}{|c|c|c|c|c|c|}
\hline $\begin{array}{l}\text { Régie } \\
\text { du } \\
\text { cinéma }\end{array}$ & $\begin{array}{l}\text { G } \\
\text { All ages. "A classification of Visa général } \\
\text { does not necessarily mean that the film is } \\
\text { of interest to children. It only means that } \\
\text { its content is not likely to be disturbing to } \\
\text { young viewers." Content may include } \\
\text { occasional violence, nudity and swearing, } \\
\text { depending on context and presentation. }\end{array}$ & $\begin{array}{l}\text { 13+ } \\
\text { No admission under } \\
13 \text { unless } \\
\text { accompanied by an } \\
\text { adult. } \\
\text { "These films contain } \\
\text { passages or sequences } \\
\text { that may offend the } \\
\text { sensibilities of } \\
\text { younger viewers." }\end{array}$ & $\begin{array}{l}\text { 16+ } \\
\text { No admission under } 16 . \\
\text { These films "present troubling } \\
\text { themes, situations or } \\
\text { behaviours and adopt a more } \\
\text { direct point of view about } \\
\text { things. They may therefore } \\
\text { contain scenes where violence, } \\
\text { horror and sexuality are more } \\
\text { graphic." }\end{array}$ & $\begin{array}{l}\mathbf{1 8 +} \\
\text { No admission under } 18 . \\
\text { "Films ... deal primarily with } \\
\text { the representation of explicit } \\
\text { sexual encounters. They may } \\
\text { also be extremely violent, } \\
\text { showing scenes of } \\
\text { hyperrealistic cruelty, torture } \\
\text { and horror. }\end{array}$ & \begin{tabular}{|l} 
Adult \\
Included under 18+, \\
with the Advisory \\
"Sexualité explicite"
\end{tabular} \\
\hline
\end{tabular}

\begin{tabular}{|c|c|c|c|c|c|}
\hline MPAA & $\begin{array}{l}\text { G } \\
\text { All ages. "...not necessarily a children's } \\
\text { film, but contains nothing that would } \\
\text { "offend parents whose younger children } \\
\text { view the motion picture." }\end{array}$ & $\begin{array}{l}\text { PG } \\
\text { "...parents may } \\
\text { consider some } \\
\text { material unsuitable } \\
\text { for their children." } \\
\text { Any of the elements } \\
\text { may be present, } \\
\text { except drug use. }\end{array}$ & $\begin{array}{l}\text { PG-13 } \\
\text { Some material may be } \\
\text { inappropriate for children } \\
\text { under } 13 \text {. }\end{array}$ & $\begin{array}{l}\text { Restricted } \\
\text { "...contain some adult material" } \\
\text { and [is] not appropriate for } \\
\text { young children. }\end{array}$ & $\begin{array}{l}\text { NC-17 } \\
\text { "...not } \\
\text { pornographic," but } \\
\text { contain[s] material } \\
\text { that most parents } \\
\text { would consider "off- } \\
\text { limits for viewing by } \\
\text { their children." }\end{array}$ \\
\hline
\end{tabular}




\section{Comparing Classifications}

A cursory review of film ratings suggests Canadian ratings are more liberal than MPAA ratings, and this is supported by Talbot, and Talbot and Ward's international comparisons of ratings, Comparing Classifications: Feature Films and Video Games $2012 \& 2013$, and $2010 \& 2011 .{ }^{225}$ Raymond Lee's 2003 report found British Columbia to be the most liberal of the provincial agencies. ${ }^{226}$ To verify assumptions and studies confirming Canada having more liberal ratings, this chapter compares the MPAA and Canadian provincial classifications for the top one hundred highest grossing films of 2013 (Table 3).

\subsection{About the Data}

The list of films was obtained, with permission, from the online service Box Office Mojo (part of Internet Movie Database, which in turn is part of Amazon). ${ }^{227}$ The box office figures are based on theatrical grosses in Canada and the United States, during the calendar year 2013. These are not necessarily the highest grossing films released that year, since the list counts box office traffic during a time period, not by film. One hundred films represent $15 \%$ of the films tracked by Box Office Mojo for that year.

Selecting high grossing films tilts the list towards major studios. Given studies and anecdotal reports that show an MPAA bias in favour of more liberal ratings for major

\footnotetext{
225 Talbot, Comparing Classifications: Feature Films and Video Games 2012 \& 2013.; Ward and Talbot, Comparing Classifications: Feature Films and Video Games 2010 \& 2011.

${ }^{226}$ Lee, Research on Community Standards.

227 "Box Office Mojo," March 25, 2014, http://www.boxofficemojo.com/.
} 
studios, the MPAA ratings for this set of films may be more liberal than for all MPAA rated films. ${ }^{228}$.

One reason for selecting the top one hundred films was to ensure the films were popular enough to have been released and rated in all Canadian jurisdictions. Some studies that start with a much larger list of films need to reduce the sample considerably to perform comparisons. For example, Talbot considered 260 films, but only 102 were classified in all jurisdictions. ${ }^{229}$ Four of the titles in the initial top one hundred were not classified in some provinces, and the Spanish language Instructions Not Included (Eugenio Derbez, 2013) was not classified in any province, so the one hundred films examined are derived from the top one hundred and five in the box office data. Keeping to one year for the analysis avoids distortion from ratings creep. Classifications are subject to change: All classifications here are as of March 2014, except for Nova Scotia, which are as of April 2014.

Table 3 shows the films listed by gross income. For each film, the classifications from the English language boards are listed, then the average of those classifications, then the Quebec rating, and finally the MPAA ratings. Noteworthy differences in the classifications are noted by highlighting as described in the table.

Comparing classifications across different systems is an imprecise science. Talbot, and Ward and Talbot, offer one possible solution: They convert all ratings to a single system, assigning points based on the age restrictions, and whether or not an age restriction is advisory or mandatory. The result is a twenty-five level generic ratings

\footnotetext{
${ }^{228}$ For example, Waguespack and Sorenson. "The Ratings Game."

229 Talbot, Comparing Classifications: Feature Films and Video Games 2012 \& 2013, 11.
} 
system, accommodating six different national systems. ${ }^{230}$ While this is a practical approach for considering many different systems and large numbers of films, it has disadvantages. For example, differences within systems are exaggerated or lost. Talbot's classification strength generic equivalent points for Ontario are $\mathrm{G}=1, \mathrm{PG}=2,14 \mathrm{~A}=7$, and $18 \mathrm{~A}=11$. The exaggeration of differences between $18 \mathrm{~A}$ and $14 \mathrm{~A}$, and especially between 14A and PG, make it difficult to compare film ratings between the English Canadian agencies. To reduce these exaggerations, Talbot notes that differences of 3 or fewer points are not significant, blurring $G$ and $P G$ together.

Talbot's generic system also makes some assumptions. For Ontario's 18A and the MPAA's R, the reports assign scores on the assumption that children under thirteen will not attend these films, even though they can. This is misleading, and would not recognize the difference application of $18 \mathrm{~A}$ in different Canadian agencies.

An alternative might be to create a set of relative strength scores specific to the classifications systems examined here, but that would still involve making some difficult decisions. For example, Quebec's 16+ rating is less restrictive than the other agencies' $18 \mathrm{~A}$, in that a sixteen-year-old can attend unaccompanied, but more restrictive than the $18 \mathrm{~A}$, in that a fourteen-year-old cannot attend under any circumstances. Yet another factor to consider is whether to weight ratings to consider the greater populations of some provinces. A restrictive rating in Ontario affects more people than a restrictive rating in Nova Scotia.

In recognition of the problems of a completely mathematical analysis, this comparison averages ratings from similar systems, and then relies on discussion rather

\footnotetext{
230 Talbot, Comparing Classifications: Feature Films and Video Games 2012 \& 2013. ; Ward and Talbot, Comparing Classifications: Feature Films and Video Games 2010 \& 2011.
} 
than charting to consider the differences from other systems. Ratings for the five English language agencies, which use almost exactly the same systems, are averaged by film. The English agency averages are then compared against the Régie ratings, and against the MPAA ratings.

\subsection{Discussion of English Language Agency Ratings}

Among the English Canadian agencies, seventy-four of one hundred films received the same classification from every agency, despite the despite the different structures and guidelines of the agencies. Lee's 2003 survey of the English agencies used a similar size sample, ninety-five films, but found only forty percent of the films received the same rating in all jurisdictions ${ }^{231}$. The lower similarity may be due to the then recent introduction of five levels in all agencies, which have now been in place for over ten years.

The number of films where the agencies did not always agree, by average rating, was G - 1, PG - 7, 14A - 14, and 18A - 4. Difference occurred at all classification levels, in approximately the same proportion as the number of films in that classification. Midlevel classifications are more likely to vary than films at the top or bottom of the levels, as there are more possibilities.

Of the twenty-six films where ratings were not the same, BC had the most films with a rating lower than some or all of the other agencies: nineteen. In descending order, the frequency of lower ratings was Nova Scotia, twelve; Ontario, ten; Manitoba, five; and

\footnotetext{
${ }^{231}$ Research on Community Standards.
} 
Alberta, four. This leaves $\mathrm{BC}$ as the most liberal agency, neighbouring Alberta and Manitoba as the most restrictive, and Ontario and Nova Scotia in the middle.

$\mathrm{BC}$ as the most liberal agency is consistent with Lee's conclusion and anecdotal comments about BC Film Classification. ${ }^{232}$ Lee found Manitoba to be most conservative, and in this analysis it is a very close second to Alberta.

The ratings analysis suggests a relationship between the structure of the agency and the consistency of ratings. Alberta and British Columbia are both relatively consistent in their respective liberal and restrictive approaches, and both are agencies where the primary reviewers are small number of full time employees. Ontario and Nova Scotia, both more inconsistent in rating higher or lower than average, are both agencies where the primary reviewers are many members of an appointed public board that meets a few days a month. There does not appear to be a relationship between guidelines and ratings.

With regard to Alberta being the most restrictive agency, it may be significant that this is only agency where reviewers do not watch adult sex films. The classification mandate excludes home video, and adult sex films are almost exclusively home video. In addition, Alberta classifiers would not see straight to video non-explicit sexploitation films such as the Girls Gone Wild series, violent exploitation films such as the Faces of Death and Bumfights series, or any festival films. By contrast, ten percent of films

${ }^{232}$ Personal communication with a member of the agency, July 2014. 
reviewed in $\mathrm{BC}$ are adult sex films, and more than two thirds of all reviewing time in Ontario is spent watching adult sex films. ${ }^{233}$

With limited official exposure to more potentially offensive material, the Alberta classifiers are working in a different cinematic context than classifiers at the other English language agencies. Classifiers in other jurisdictions may spend hours watching explicit sex, and then view a mainstream film with occasional nudity and a sexually suggestive scene. Desensitization by long exposure to more extreme materials may lead them to find moments of challenging material in mainstream films less objectionable or even less noticeable. At most, the effect would be slight, since there are other factors, and Alberta had the same ratings as the other provinces for seventy-eight of the one hundred films. Manitoba is almost as restrictive as Alberta, has a public board, and classifies Home Video including Adult Sex Films.

\section{A Inconsistency}

The analysis above considered all applications of $18 \mathrm{~A}$ to be equal, but the classification is slightly more restrictive in Manitoba and Nova Scotia, where no one under 14 can view an 18A film, regardless of parental accompaniment. As it is more restrictive, it may have been used less in those provinces, in favour of 14A. There were seven films where one or more provinces used the 18A classification, when others used 14A. Of those seven films, Alberta always used 18A, Manitoba used it six times; Nova Scotia, British Columbia, and Ontario used it twice. It does not appear to be the case that

\footnotetext{
${ }^{233}$ According to figures from the latest available annual reports, Ontario reviewed 296,948 minutes adult sex content out of 418,670 total minutes screened in 2011. British Columbia reviewed 190 adult sex films out of 1725 films and trailers in 2013. Ontario Film Review Board Annual Report 2010/2011.;2011 Annual Report: Administration of the Motion Picture Act.
} 
Nova Scotia and Manitoba used 18A less frequently than other provinces, even though it is more restrictive.

Talbot, and Ward and Talbot, note that a wider range of classifications results in more flexible decisions, and imply that the relative strictness or liberalism of an agency can be a result of its available classifications. For example, Ontario's relatively liberal classifications are partly credited to its use of the 14 classification. ${ }^{234}$ It would be faulty logic to discount the use of the stricter 18A in Nova Scotia and Manitoba on the grounds that no other option is available to them. The agencies could add another rating, or modify the existing rating. Or the other agencies could make their $18 \mathrm{~A}$ stricter to match Nova Scotia and Manitoba. ${ }^{235}$

Taking the slightly stricter 18A into account, Manitoba and Nova Scotia should be considered as slightly more restrictive than the classification averages alone suggest. At most this concerns six and two films respectively. Overall Alberta would still be more restrictive than Manitoba, and Nova Scotia would remain well in the middle.

\section{Advisory Notices}

The analysis above considered only the classifications, not the advisory statements that typically accompany the classifications. Advisory statements do not have the legal weight of age restrictions, but they could be used to moderate difference in classifications. On reviewing the advisories for the most popular film where the agencies

${ }^{234}$ Comparing Classifications: Feature Films and Video Games 2010 \& 2011, 6.

${ }^{235}$ In 2005, a member of the Ontario Board expressed a desire to add a lower age limit to 18A, making it the same as 18A in Manitoba and Nova Scotia, but to date there has not been any change. (Personal communication with a member of the Board, September, 2005.) Film rating systems are rarely a government priority. 
agreed, and the most popular film where the agencies did not agree, there does not seem to be consistency of advisories for the same classification, nor does it appear they are being used to moderate classification differences.

Advisories for Hunger Games: Catching Fire rated PG in all jurisdictions are: BC: Violence

AB: Violence, Not Recommended For Young Children

MB: Not Recommended For Young Children, Violence, Language May Offend

ON: Frightening Scenes, Violence, Not Recommended for Children

NS: Violence, Disturbing Content

All agencies gave the same rating, but highlighted different concerns in their advisory notices. All agencies note violence, but only two feel it necessary to warn about young children, and only Ontario adds Frightening Scenes. Nova Scotia is alone on pointing out disturbing content, but does not add a young child warning, and only Manitoba notes a language concern, even though they have already warned about young children.

The classifications and advisories for Fast and Furious Six are:

BC: 14A, Frequent Violence

AB: 14A, Violence

MB: 14A, Not Recommended For Children, Violence, Language May Offend

ON: PG, Violence, Language May Offend, Not Recommended for Young

Children

NS: PG, Violence, Not Recommended For Young Children 
Despite the different classifications, all agencies provided an advisory about violence. Nova Scotia and Ontario use the lower PG rating, and add the warning "not recommended for young children," while Manitoba uses the higher 14A rating, and more broadly states "not recommended for children." This emphasizes rather than moderates the use of a different classification. Also noteworthy is that Manitoba and Ontario have the same advisories for Violence and Language, even though they use 14A and PG respectively.

\subsection{Comparison with Quebec Classifications}

The most significant finding is that eighty of one hundred films have approximately the same classification as the average of ratings from the English language agencies. This includes use of $16+$ in place of $18 \mathrm{~A}$, four times. Each time $16+$ used in Quebec, all other provinces used 18A. As noted above, this could be considered more liberal or more restrictive.

There are five uses of $13+$ when the average of the other agencies is $18 \mathrm{~A}$, which is clearly more liberal. This is more liberal than average, but not more liberal than every province. In four of these five films, at least one other agency used the 14A classification, close to $13+$.

There are also three films classified 13+, requiring adult accompaniment, where the English agency average was the unrestricted PG. For two of the three, some provinces used the roughly equivalent 14A. This leaves The Mortal Instruments: City of Bones as the only film to be age restricted in Quebec and not in any other province. 
A G rating was applied in Quebec to eight films where the English agency average was 14A. In three cases, at least one other agency used the unrestricted PG classification. In the other five, Quebec is only agency to not have age restrictions on a film which is age restricted in every other province.

These comparisons show that Quebec is slightly more liberal than the Canadian average. Only one film is clearly more restricted, and six films are classified more liberally. Comparing against British Columbia, the most liberal English agency, there are eighteen films where the ratings differ. Six have a higher classification, eight have a lower classification, and four have the difficult to compare $16+$ versus $18 \mathrm{~A}$. This suggests Quebec is about as liberal as British Columbia.

Lee did not consider Quebec in his survey. ${ }^{236}$ Like BC Film Classification, the Régie du cinéma consists of employees, however the Régie has stronger guidelines requires consideration of elements. The data for Quebec supports the existence of a relationship between the structure of the agency and the consistency of the ratings, and no relationship between use of guidelines and ratings.

Quebec ratings are within the average range of Canadian ratings from the English agencies. Therefore, since the English agency rating options more closely resemble the MPAA rating options, the average of the English agency ratings is used to compare Canada's ratings with the MPAA ratings.

${ }^{236}$ Research on Community Standards. 


\subsection{Comparison with MPAA Classifications}

The G and PG classifications are essentially the same in Canada and the United States. The MPAA's PG-13 and English Canadian agencies' 14A are roughly equivalent, but PG-13 is more liberal as it is an advisory, not a restriction. The MPAA's Restricted and Canada's 18A are also roughly equivalent, but Restricted is more liberal. Restricted does not allow unaccompanied children under 17, while Canada's 18A does not allow children under 18. In addition, the MPAA Restricted has no lower age limit.

Considering the rough equivalents, MPAA ratings are different than the Canadian average for seventy-two of one hundred films, and in all cases the MPAA rating is more restrictive. The difference between the MPAA and the Canadian agencies is much greater than differences among the Canadian agencies.

The MPAA classified nine films PG where the Canadian average was G. For eight of those nine films, the Canadian agencies were unanimous in the G rating. For the use of the G classification, Canada is clearly more liberal.

There were thirty-four films rated an average of PG in Canada that received a PG13 rating from the MPAA. Some Canadian agencies gave 14A ratings to these films, but other agencies gave $\mathrm{G}$ ratings. As there is no age restriction on admission with the PG-13 classification, American classifiers may feel freer to apply it than their Canadian counterparts, and it may be considered desirable by the industry.

$\mathrm{G}$ is the least restrictive rating, and therefore in theory has the largest potential audience, but among the top ten films of 2013 there is only one film rated G by the MPAA. That suggests it is not necessarily the most desirable rating. Six of the top ten have the MPAA's PG-13. This is the highest classification that does not have an age 
restriction, and might be considered the sweet spot for films seeking to maximize their appeal. All ages can attend, but there is the promise of elements that are intended for mature viewers. The greater use of PG in Canada for films rated PG-13 in the United States may be evidence of Canadian liberalism, but it may also be evidence of the MPAA supporting industry objectives.

The MPAA used the Restricted classification for twenty-nine films that had an average classification of 14A in Canada. For twenty-six of those films, the 14A was unanimous among the English Canadian agencies. The higher age limit in the United States is clearly more restrictive. As noted above, the MPAA does not have a mid-teen age restricted classification, but this is no excuse for a more restrictive system. Mid-teen ager restricted classifications are common in other systems, including those of Australia, Germany, France, Norway, Sweden, Great Britain, New Zealand, Ireland, South Africa, and Singapore. Canada's use of a mid-teen rating for these twenty-nine films makes it more liberal.

The MPAA Restricted classification is slightly more liberal than the $18 \mathrm{~A}$ classification in Canada. There are nine films that are Restricted in the United States, and 18A in Canada, though for four of those films, at least one agency used a 14A rating.

With seventy-two films rated significantly higher than the Canadian average, and nine rated slightly lower, the MPAA ratings are clearly more restrictive than the ratings in Canada, in every category. This is consistent with the analysis of Talbot, and Ward and Talbot. $^{237}$

\footnotetext{
237 Talbot, Comparing Classifications: Feature Films and Video Games 2012 \& 2013.; Ward and Talbot, Comparing Classifications: Feature Films and Video Games 2010 \& 2011.
} 
The conclusion that Canada's ratings are more liberal appears to contradict Waguespack and Sorenson's conclusion that industry boards such as the MPAA give more liberal ratings to MPAA member films than government boards do, but they were comparing the chances of receiving a Restricted rating between independent films and MPAA member films, and working with much larger samples. ${ }^{238}$ This sample may be too small to show the difference, particularly as it is the most popular films, and therefore primarily films from major studios. Most of the research and criticism of the MPAA is focused on the use of the higher Restricted and NC-17 classifications. Waguespack and Sorenson analyze the Restricted category exclusively, and ignore MPAA's use of PG and PG-13 where other jurisdictions feel a lower classification is justified.

As with Alberta, the most restrictive agency in Canada, the members of the MPAA do not classify home video, therefore they do not classify adult sex films, or any kind of exploitation films. Nor do they classify all theatrical releases. To a greater extent than Alberta, the MPAA classifiers are only rating a subset of films, and this has been the position of the organization since its founding in 1922.

Until 1968, the MPAA rarely permitted its members to produce films where admission would require adult accompaniment or be for adults only. The Canadian agencies had accepted the practice of requiring adult accompaniment or limiting admission to adults decades earlier. By 1968, when the MPAA decided to have a classification for films intended for adults, the Canadian agencies were routinely reviewing films at the threshold of criminal obscenity.

\footnotetext{
${ }^{238}$ Waguespack and Sorenson's overall sample was 2,404 films, and he used 874 to compare the MPAA with Ontario. The sample considered here is 100 films. "The Ratings Game."
} 
The other significant difference between the MPAA and the Canadian agencies is a lack of public accountability. Although public input to the Canadian Boards varies, and BC Film Classification no longer reports directly to an elected official, all of the agencies are part of the machinery of provincial or territorial government, and their common mandate is to serve the public. In four provinces, films are regulated by the same government departments that oversee payday loans, debt collection companies, funeral homes, liquor stores, travel agencies, and similar organizations. The MPAA is a private organization that is run by and answerable only to part of the film industry.

\section{Fear of Complaints}

The MPAA was founded to oppose government censorship. It has to demonstrate, on an on-going basis, that it can do a better job of regulating film content than governments. In other words, in order to avoid complaints of being too soft, it may overcompensate by being too strong. It cannot take the risks or use the authority that government agencies can.

In British Columbia, in 2011, two-thirds of the recorded complaints received were that classification was too low (too liberal). ${ }^{239}$ Other agencies report complaints about ratings are evenly split between too restrictive and too liberal. ${ }^{240}$ Though the agencies need to be attentive to public concerns, they do not need to fear them. There is no danger of another authority taking over film classification if there are complaints. When the

\footnotetext{
${ }^{239}$ Consumer Protection BC, 2011 Annual Report: Administration of the Motion Picture Act.

${ }^{240}$ Personal communications with members of three film classifications agencies between September 2005 and November 2014.
} 
agencies receive some complaints about being too liberal, and some about being too restrictive, they can conclude that they are performing well.

The private MPAA, with the mandate of preventing government censorship, would have a much greater fear of complaints. Too many might lead to the government taking over film classification. Fear of complaints is one factor that may encourage the MPAA to give relatively restrictive ratings.

\subsection{Conclusion}

Across Canada, most films get the same classification. For the one quarter of classifications that differ, British Columbia and Quebec are the most liberal, Alberta and Manitoba are the most restrictive, and Ontario and Nova Scotia are in the middle. British Columbia, Quebec, and Alberta all have a small number of full time employees, which may be responsible for the more consistent ratings than those from the larger public boards of Ontario and Nova Scotia. There does not appear to be any relationship between the liberalism of the classifications and the operation or structure of the agency.

Compared with Canadian classifications, the MPAA ratings are frequently more restrictive. As in Alberta, the MPAA classifiers do not review the full range of distributed films, particularly adult sex films, and this may be a factor in issuing more restrictive ratings. The MPAA has a history of not using age restrictions, long used in Canada, and the lack of a mid-teen restriction may force ratings higher. However, MPAA classifications are more restrictive even for films rated $\mathrm{G}$ in Canada. 
Table 3 - Classifications for the Most Popular films of 2013

Highlighted for BC, AB, MB, ON, NS: Films where agencies used different classifications.

Highlighted for AVG: Films where one or more agencies, but not all, used 18A classification.

Highlighted for QC: Films where QC classification different than the English Canadian Average.

Asterisk for QC: Film where QC classification different from BC.

Highlighted for MPAA: Films where MPAA classification different than the English Canadian Average.

\begin{tabular}{|l|l|l|l|l|l|l|l|l|}
\hline Film & BC & AB & MB & ON & NS & AVG & QC & MPAA \\
\hline The Hunger Games: Catching Fire & PG & PG & PG & PG & PG & PG & G & PG-13 \\
\hline Iron Man 3 & PG & PG & PG & PG & PG & PG & G & PG-13 \\
\hline Frozen & G & G & G & G & G & G & G & PG \\
\hline Despicable Me 2 & G & G & G & G & G & G & G & PG \\
\hline Man of Steel & PG & PG & PG & PG & PG & PG & G & PG-13 \\
\hline Gravity & PG & PG & PG & PG & PG & PG & G & PG-13 \\
\hline Monsters University & G & G & G & G & G & G & G & G \\
\hline $\begin{array}{l}\text { The Hobbit: The Desolation of } \\
\text { Smaug }\end{array}$ & PG & PG & PG & PG & PG & PG & G & PG-13 \\
\hline Fast \& Furious 6 & $14 \mathrm{~A}$ & $14 \mathrm{~A}$ & $14 \mathrm{~A}$ & PG & PG & $14 \mathrm{~A}$ & $13+$ & PG-13 \\
\hline Oz The Great and Powerful & PG & PG & PG & PG & PG & PG & G & PG \\
\hline Star Trek Into Darkness & PG & PG & PG & PG & PG & PG & G & PG-13 \\
\hline Thor: The Dark World & PG & PG & PG & PG & PG & PG & G & PG-13 \\
\hline World War Z & $14 A$ & $14 A$ & $14 A$ & $14 A$ & $14 A$ & $14 A$ & $13+$ & PG-13 \\
\hline
\end{tabular}




\begin{tabular}{|c|c|c|c|c|c|c|c|c|}
\hline Film & BC & $\mathbf{A B}$ & MB & $\mathbf{O N}$ & NS & $\mathbf{A V G}$ & QC & MPAA \\
\hline The Croods & $\mathrm{G}$ & $\mathrm{G}$ & $\mathrm{G}$ & G & $\mathrm{G}$ & $\mathrm{G}$ & $\mathrm{G}$ & $\mathrm{PG}$ \\
\hline The Heat & $14 \mathrm{~A}$ & $14 \mathrm{~A}$ & $14 \mathrm{~A}$ & $14 \mathrm{~A}$ & $14 \mathrm{~A}$ & $14 \mathrm{~A}$ & $13+$ & $\mathrm{R}$ \\
\hline We're the Millers & $14 \mathrm{~A}$ & $14 \mathrm{~A}$ & $14 \mathrm{~A}$ & $14 \mathrm{~A}$ & $14 \mathrm{~A}$ & $14 \mathrm{~A}$ & $13+$ & $\mathrm{R}$ \\
\hline American Hustle & $14 \mathrm{~A}$ & $14 \mathrm{~A}$ & $14 \mathrm{~A}$ & $14 \mathrm{~A}$ & $14 \mathrm{~A}$ & $14 \mathrm{~A}$ & $\mathrm{G}^{*}$ & $\mathrm{R}$ \\
\hline The Great Gatsby (2013) & PG & PG & PG & PG & PG & $\mathrm{PG}$ & G & PG-13 \\
\hline The Conjuring & $14 \mathrm{~A}$ & $14 \mathrm{~A}$ & $14 \mathrm{~A}$ & $14 \mathrm{~A}$ & $14 \mathrm{~A}$ & $14 \mathrm{~A}$ & $13+$ & $\mathrm{R}$ \\
\hline Identity Thief & $14 \mathrm{~A}$ & $14 \mathrm{~A}$ & $14 \mathrm{~A}$ & $14 \mathrm{~A}$ & $14 \mathrm{~A}$ & $14 \mathrm{~A}$ & $13+$ & $\mathrm{R}$ \\
\hline Grown Ups 2 & PG & PG & PG & PG & PG & PG & G & PG-13 \\
\hline The Wolverine & $14 \mathrm{~A}$ & $14 \mathrm{~A}$ & $14 \mathrm{~A}$ & PG & $14 \mathrm{~A}$ & $14 \mathrm{~A}$ & $13+$ & PG-13 \\
\hline $\begin{array}{l}\text { Anchorman 2: The Legend } \\
\text { Continues }\end{array}$ & $\mathrm{PG}$ & $14 \mathrm{~A}$ & $14 \mathrm{~A}$ & $14 \mathrm{~A}$ & $\mathrm{PG}$ & $14 \mathrm{~A}$ & G & PG-13 \\
\hline Lone Survivor & $14 \mathrm{~A}$ & $14 \mathrm{~A}$ & $14 \mathrm{~A}$ & $14 \mathrm{~A}$ & $14 \mathrm{~A}$ & $14 \mathrm{~A}$ & $13+$ & $\mathrm{R}$ \\
\hline G.I. Joe: Retaliation & $\mathrm{PG}$ & $14 \mathrm{~A}$ & $14 \mathrm{~A}$ & PG & $\mathrm{PG}$ & $\mathrm{PG}$ & $13+*$ & PG-13 \\
\hline $\begin{array}{l}\text { Cloudy with a Chance of Meatballs } \\
2\end{array}$ & $\mathrm{G}$ & $\mathrm{G}$ & $\mathrm{G}$ & $\mathrm{G}$ & $\mathrm{G}$ & $\mathrm{G}$ & $\mathrm{G}$ & PG \\
\hline Now You See Me & $\mathrm{PG}$ & $\overline{P G}$ & $P G$ & $P \mathrm{PG}$ & $\overline{P G}$ & $\overline{P G}$ & $\mathrm{G}$ & PG-13 \\
\hline The Wolf of Wall Street & $18 \mathrm{~A}$ & $18 \mathrm{~A}$ & $18 \mathrm{~A}$ & $18 \mathrm{~A}$ & $18 \mathrm{~A}$ & $18 \mathrm{~A}$ & $16+*$ & $\mathrm{R}$ \\
\hline Lee Daniels' The Butler & PG & $14 \mathrm{~A}$ & $14 \mathrm{~A}$ & $14 \mathrm{~A}$ & $14 \mathrm{~A}$ & $14 \mathrm{~A}$ & $\mathrm{G}$ & PG-13 \\
\hline The Hangover Part III & $14 \mathrm{~A}$ & $14 \mathrm{~A}$ & $14 \mathrm{~A}$ & $14 \mathrm{~A}$ & $14 \mathrm{~A}$ & $14 \mathrm{~A}$ & $13+$ & $\mathrm{R}$ \\
\hline Epic & $\mathrm{G}$ & $\mathrm{G}$ & $\mathrm{G}$ & PG & PG & $\mathrm{G}$ & G & PG \\
\hline Captain Phillips & PG & PG & $14 \mathrm{~A}$ & $14 \mathrm{~A}$ & PG & PG & $13+*$ & PG-13 \\
\hline Jackass Presents: Bad Grandpa & $14 \mathrm{~A}$ & $14 \mathrm{~A}$ & $14 \mathrm{~A}$ & $14 \mathrm{~A}$ & $14 \mathrm{~A}$ & $14 \mathrm{~A}$ & $13+$ & $\mathrm{R}$ \\
\hline Pacific Rim & PG & PG & PG & PG & PG & PG & $\mathrm{G}$ & PG-13 \\
\hline This is the End & $18 \mathrm{~A}$ & $18 \mathrm{~A}$ & $18 \mathrm{~A}$ & $18 \mathrm{~A}$ & $18 \mathrm{~A}$ & $18 \mathrm{~A}$ & $13+*$ & $\mathrm{R}$ \\
\hline
\end{tabular}




\begin{tabular}{|c|c|c|c|c|c|c|c|c|}
\hline Film & BC & AB & MB & $\mathbf{O N}$ & NS & AVG & $\mathbf{Q C}$ & MPAA \\
\hline Olympus Has Fallen & $14 \mathrm{~A}$ & $14 \mathrm{~A}$ & $14 \mathrm{~A}$ & $14 \mathrm{~A}$ & $14 \mathrm{~A}$ & $14 \mathrm{~A}$ & $13+$ & $\mathrm{R}$ \\
\hline 42 & PG & PG & PG & $\mathrm{PG}$ & PG & PG & G & \begin{tabular}{|l|} 
PG-13 \\
\end{tabular} \\
\hline Elysium & $14 \mathrm{~A}$ & $14 \mathrm{~A}$ & $14 \mathrm{~A}$ & $14 \mathrm{~A}$ & $14 \mathrm{~A}$ & $14 \mathrm{~A}$ & $13+$ & $\mathrm{R}$ \\
\hline Planes & G & G & G & G & G & $\mathrm{G}$ & $\mathrm{G}$ & PG \\
\hline The Lone Ranger & PG & PG & PG & $\mathrm{PG}$ & PG & PG & G & PG-13 \\
\hline Oblivion & PG & $\mathrm{PG}$ & PG & PG & PG & PG & G & PG-13 \\
\hline Insidious Chapter 2 & $14 \mathrm{~A}$ & $14 \mathrm{~A}$ & $14 \mathrm{~A}$ & $14 \mathrm{~A}$ & $14 \mathrm{~A}$ & $14 \mathrm{~A}$ & $13+$ & \begin{tabular}{|l|} 
PG-13 \\
\end{tabular} \\
\hline Saving Mr. Banks & G & PG & PG & $\mathrm{PG}$ & PG & PG & $\mathrm{G}$ & \begin{tabular}{|l|} 
PG-13 \\
\end{tabular} \\
\hline Turbo & G & $\mathrm{G}$ & G & $\mathrm{G}$ & G & $\mathrm{G}$ & G & PG \\
\hline 2 Guns & $14 \mathrm{~A}$ & $14 \mathrm{~A}$ & $14 \mathrm{~A}$ & $14 \mathrm{~A}$ & $14 \mathrm{~A}$ & $14 \mathrm{~A}$ & $13+$ & $\mathrm{R}$ \\
\hline White House Down & $14 \mathrm{~A}$ & $14 \mathrm{~A}$ & $14 \mathrm{~A}$ & $14 \mathrm{~A}$ & PG & $14 \mathrm{~A}$ & $13+$ & PG-13 \\
\hline Mama & $14 \mathrm{~A}$ & $14 \mathrm{~A}$ & PG & $14 \mathrm{~A}$ & $14 \mathrm{~A}$ & $14 \mathrm{~A}$ & $13+$ & PG-13 \\
\hline Safe Haven & PG & $\mathrm{PG}$ & PG & $\mathrm{PG}$ & $\mathrm{PG}$ & $\mathrm{PG}$ & $\mathrm{G}$ & \begin{tabular}{|l|} 
PG-13 \\
\end{tabular} \\
\hline The Smurfs 2 & G & $\mathrm{G}$ & $\mathrm{G}$ & $\mathrm{G}$ & $\mathrm{G}$ & $\bar{G}$ & $\mathrm{G}$ & PG \\
\hline The Best Man Holiday & $14 \mathrm{~A}$ & $14 \mathrm{~A}$ & $14 \mathrm{~A}$ & $14 \mathrm{~A}$ & $14 \mathrm{~A}$ & $14 \mathrm{~A}$ & $\mathrm{G}^{*}$ & $\mathrm{R}$ \\
\hline Percy Jackson: Sea of Monsters & PG & $\mathrm{PG}$ & $\mathrm{PG}$ & PG & PG & $\mathrm{PG}$ & $\mathrm{G}$ & PG \\
\hline A Good Day to Die Hard & $14 \mathrm{~A}$ & $14 \mathrm{~A}$ & $14 \mathrm{~A}$ & $14 \mathrm{~A}$ & $14 \mathrm{~A}$ & $14 \mathrm{~A}$ & $13+$ & $\mathrm{R}$ \\
\hline Warm Bodies & PG & $14 \mathrm{~A}$ & $14 \mathrm{~A}$ & $\mathrm{PG}$ & $14 \mathrm{~A}$ & $14 \mathrm{~A}$ & $13+*$ & PG-13 \\
\hline Jack the Giant Slayer & PG & $\mathrm{PG}$ & $\mathrm{PG}$ & $\mathrm{PG}$ & $\mathrm{PG}$ & $\mathrm{PG}$ & G & PG-13 \\
\hline The Purge & $14 \mathrm{~A}$ & $14 \mathrm{~A}$ & $14 \mathrm{~A}$ & $14 \mathrm{~A}$ & $14 \mathrm{~A}$ & $14 \mathrm{~A}$ & $13+$ & $\mathrm{R}$ \\
\hline Last Vegas & PG & PG & PG & PG & PG & PG & $\mathrm{G}$ & PG-13 \\
\hline Ender's Game & PG & PG & $\mathrm{PG}$ & PG & PG & PG & G & PG-13 \\
\hline Prisoners & $14 \mathrm{~A}$ & $14 \mathrm{~A}$ & $14 \mathrm{~A}$ & $14 \mathrm{~A}$ & $14 \mathrm{~A}$ & $14 \mathrm{~A}$ & $13+$ & $\mathrm{R}$ \\
\hline
\end{tabular}




\begin{tabular}{|c|c|c|c|c|c|c|c|c|}
\hline Film & BC & AB & MB & $\mathbf{O N}$ & NS & AVG & QC & MPAA \\
\hline After Earth & PG & PG & PG & PG & PG & PG & $\mathrm{G}$ & PG-13 \\
\hline The Secret Life of Walter Mitty & G & PG & PG & PG & PG & PG & G & $\mathrm{PG}$ \\
\hline Escape From Planet Earth & G & $\mathrm{G}$ & $\mathrm{PG}$ & PG & $\mathrm{PG}$ & $\mathrm{PG}$ & $\mathrm{G}$ & $\mathrm{PG}$ \\
\hline 12 Years a Slave & $14 \mathrm{~A}$ & $14 \mathrm{~A}$ & $14 \mathrm{~A}$ & $14 \mathrm{~A}$ & $14 \mathrm{~A}$ & $14 \mathrm{~A}$ & $13+$ & $\mathrm{R}$ \\
\hline Free Birds & G & $\mathrm{G}$ & $\mathrm{G}$ & G & G & G & $\mathrm{G}$ & PG \\
\hline Hansel and Gretel: Witch Hunters & $18 \mathrm{~A}$ & $18 \mathrm{~A}$ & $18 \mathrm{~A}$ & $14 \mathrm{~A}$ & $14 \mathrm{~A}$ & $18 \mathrm{~A}$ & $13+*$ & $\mathrm{R}$ \\
\hline Evil Dead (2013) & $18 \mathrm{~A}$ & $18 \mathrm{~A}$ & $18 \mathrm{~A}$ & $18 \mathrm{~A}$ & $18 \mathrm{~A}$ & $18 \mathrm{~A}$ & $16+^{*}$ & $\mathrm{R}$ \\
\hline Red 2 & PG & PG & PG & PG & $\mathrm{PG}$ & PG & $\mathrm{G}$ & PG-13 \\
\hline The Call & $14 \mathrm{~A}$ & $14 \mathrm{~A}$ & $14 \mathrm{~A}$ & $14 \mathrm{~A}$ & $14 \mathrm{~A}$ & $14 \mathrm{~A}$ & $13+$ & $\mathrm{R}$ \\
\hline Pain and Gain & $14 \mathrm{~A}$ & $18 \mathrm{~A}$ & $18 \mathrm{~A}$ & $18 \mathrm{~A}$ & $18 \mathrm{~A}$ & $18 \mathrm{~A}$ & $13+$ & $\mathrm{R}$ \\
\hline Gangster Squad & $14 \mathrm{~A}$ & $18 \mathrm{~A}$ & $18 \mathrm{~A}$ & $14 \mathrm{~A}$ & $14 \mathrm{~A}$ & $14 \mathrm{~A}$ & $13+$ & $\mathrm{R}$ \\
\hline Jurassic Park 3D & PG & PG & PG & $\mathrm{PG}$ & $\mathrm{PG}$ & PG & $\mathrm{G}$ & PG-13 \\
\hline The Internship & PG & $\mathrm{PG}$ & PG & $\mathrm{PG}$ & $\mathrm{PG}$ & $\mathrm{PG}$ & $\mathrm{G}$ & PG-13 \\
\hline Snitch & PG & $14 \mathrm{~A}$ & $14 \mathrm{~A}$ & $\mathrm{PG}$ & $14 \mathrm{~A}$ & $14 \mathrm{~A}$ & $13+*$ & PG-13 \\
\hline Riddick & $18 \mathrm{~A}$ & $18 \mathrm{~A}$ & $18 \mathrm{~A}$ & $14 \mathrm{~A}$ & $18 \mathrm{~A}$ & $18 \mathrm{~A}$ & $13+*$ & $\mathrm{R}$ \\
\hline 47 Ronin & PG & $\mathrm{PG}$ & $\mathrm{PG}$ & $\mathrm{PG}$ & PG & $\mathrm{PG}$ & $\mathrm{G}$ & PG-13 \\
\hline August: Osage County & $14 \mathrm{~A}$ & $14 \mathrm{~A}$ & $14 \mathrm{~A}$ & $14 \mathrm{~A}$ & $14 \mathrm{~A}$ & $14 \mathrm{~A}$ & $\mathrm{G}^{*}$ & $\mathrm{R}$ \\
\hline Philomena & PG & $\mathrm{PG}$ & PG & $\mathrm{PG}$ & $\mathrm{PG}$ & $\mathrm{PG}$ & $\mathrm{G}$ & \begin{tabular}{|l|} 
PG-13 \\
\end{tabular} \\
\hline The Family (2013) & $14 \mathrm{~A}$ & $14 \mathrm{~A}$ & $14 \mathrm{~A}$ & $14 \mathrm{~A}$ & $14 \mathrm{~A}$ & $14 \mathrm{~A}$ & $13+$ & $\mathrm{R}$ \\
\hline Walking with Dinosaurs & G & PG & $\mathrm{G}$ & PG & PG & $\mathrm{PG}$ & $\mathrm{G}$ & PG \\
\hline Carrie (2013) & $14 \mathrm{~A}$ & $14 \mathrm{~A}$ & $14 \mathrm{~A}$ & $14 \mathrm{~A}$ & $14 \mathrm{~A}$ & $14 \mathrm{~A}$ & $13+$ & $\mathrm{R}$ \\
\hline Texas Chainsaw 3D & $18 \mathrm{~A}$ & $18 \mathrm{~A}$ & $18 \mathrm{~A}$ & $18 \mathrm{~A}$ & $18 \mathrm{~A}$ & $18 \mathrm{~A}$ & $16+*$ & $\mathrm{R}$ \\
\hline R.I.P.D. & PG & PG & PG & PG & PG & PG & G & \begin{tabular}{|l|} 
PG-13 \\
\end{tabular} \\
\hline
\end{tabular}




\begin{tabular}{|c|c|c|c|c|c|c|c|c|}
\hline Film & BC & $\mathbf{A B}$ & MB & $\mathbf{O N}$ & NS & AVG & QC & MPAA \\
\hline Blue Jasmine & PG & $\mathrm{PG}$ & $\mathrm{PG}$ & $14 \mathrm{~A}$ & $14 \mathrm{~A}$ & $\mathrm{PG}$ & $\mathrm{G}$ & PG-13 \\
\hline Side Effects (2013) & $14 \mathrm{~A}$ & $14 \mathrm{~A}$ & $14 \mathrm{~A}$ & $14 \mathrm{~A}$ & $\mathrm{PG}$ & $14 \mathrm{~A}$ & $13+$ & $\mathrm{R}$ \\
\hline Scary Movie 5 & $14 \mathrm{~A}$ & $14 \mathrm{~A}$ & $14 \mathrm{~A}$ & $14 \mathrm{~A}$ & $14 \mathrm{~A}$ & $14 \mathrm{~A}$ & $13+$ & PG-13 \\
\hline $\begin{array}{l}\text { The Mortal Instruments: City of } \\
\text { Bones }\end{array}$ & $\mathrm{PG}$ & $\mathrm{PG}$ & $\mathrm{PG}$ & $\mathrm{PG}$ & $P G$ & $P G$ & $13+*$ & PG-13 \\
\hline Delivery Man & $\mathrm{PG}$ & $P G$ & $P G$ & PG & PG & PG & $\mathrm{G}$ & PG-13 \\
\hline Grudge Match & PG & $14 \mathrm{~A}$ & $14 \mathrm{~A}$ & $14 \mathrm{~A}$ & PG & $14 \mathrm{~A}$ & $\mathrm{G}$ & PG-13 \\
\hline One Direction: This is Us & $\mathrm{G}$ & $\mathrm{G}$ & $\mathrm{G}$ & $\mathrm{G}$ & G & $\mathrm{G}$ & $\mathrm{G}$ & PG \\
\hline Kick-Ass 2 & $14 \mathrm{~A}$ & $18 \mathrm{~A}$ & $18 \mathrm{~A}$ & $14 \mathrm{~A}$ & $14 \mathrm{~A}$ & $14 \mathrm{~A}$ & $13+$ & $\mathrm{R}$ \\
\hline Dallas Buyers Club & $14 \mathrm{~A}$ & $18 \mathrm{~A}$ & $18 \mathrm{~A}$ & $18 \mathrm{~A}$ & $14 \mathrm{~A}$ & $18 \mathrm{~A}$ & $13+$ & $\mathrm{R}$ \\
\hline Rush (2013) & $14 \mathrm{~A}$ & $14 \mathrm{~A}$ & $14 \mathrm{~A}$ & $14 \mathrm{~A}$ & $14 \mathrm{~A}$ & $14 \mathrm{~A}$ & $\mathrm{G}^{*}$ & $\mathrm{R}$ \\
\hline The Host (2013) & PG & PG & PG & PG & PG & PG & $\mathrm{G}$ & PG-13 \\
\hline The World's End & $14 \mathrm{~A}$ & $14 \mathrm{~A}$ & $14 \mathrm{~A}$ & $14 \mathrm{~A}$ & $14 \mathrm{~A}$ & $14 \mathrm{~A}$ & $13+$ & $\mathrm{R}$ \\
\hline 21 and Over & $14 \mathrm{~A}$ & $18 \mathrm{~A}$ & $14 \mathrm{~A}$ & $14 \mathrm{~A}$ & $14 \mathrm{~A}$ & $14 \mathrm{~A}$ & $13+$ & $\mathrm{R}$ \\
\hline Her (2013) & $14 \mathrm{~A}$ & $14 \mathrm{~A}$ & $14 \mathrm{~A}$ & $14 \mathrm{~A}$ & $14 \mathrm{~A}$ & $14 \mathrm{~A}$ & $\mathrm{G}^{*}$ & $\mathrm{R}$ \\
\hline Escape Plan & $14 \mathrm{~A}$ & $14 \mathrm{~A}$ & $14 \mathrm{~A}$ & $14 \mathrm{~A}$ & $14 \mathrm{~A}$ & $14 \mathrm{~A}$ & $13+$ & $\mathrm{R}$ \\
\hline Don Jon & $18 \mathrm{~A}$ & $18 \mathrm{~A}$ & $18 \mathrm{~A}$ & $18 \mathrm{~A}$ & $18 \mathrm{~A}$ & $18 \mathrm{~A}$ & $16+*$ & $\mathrm{R}$ \\
\hline The Incredible Burt Wonderstone & PG & PG & PG & $\mathrm{PG}$ & $\mathrm{PG}$ & $\mathrm{PG}$ & $\mathrm{G}$ & PG-13 \\
\hline The Big Wedding & PG & $14 \mathrm{~A}$ & $14 \mathrm{~A}$ & $14 \mathrm{~A}$ & $14 \mathrm{~A}$ & $14 \mathrm{~A}$ & $13+*$ & $\mathrm{R}$ \\
\hline Mud & $\mathrm{PG}$ & $\mathrm{PG}$ & $\mathrm{PG}$ & $\mathrm{PG}$ & $\mathrm{PG}$ & $\mathrm{PG}$ & $\mathrm{G}$ & PG-13 \\
\hline
\end{tabular}




\section{Case Study: Avatar}

Avatar, the highest grossing film to date, is the quintessential mainstream film, and a good example of a typical classification. It was written and directed by James Cameron, an established Hollywood director who previously directed the big budget and high grossing, PG-13 rated, Titanic (1997). The stars, Sam Worthington, Zoe Saldana, Sigourney Weaver, and Stephen Lang, are well-established actors with backgrounds in television and film, and the lead production company was Twentieth Century Fox. Computer graphics and 3D techniques required work from twenty different companies. The budget is estimated to have been $\$ 237,000,000 .^{241}$

The story is an uninspired science-fiction drama of a corporation attempting to obtain a McGuffin from a distant planet, which is inhabited by peaceful but uncooperative aliens. A boy from the corporation falls in love with a native girl, and the evil plans of the corporation are thwarted. The story is similar to Dances with Wolves (Kevin Costner, 1990), Pocahontas (Mike Gabriel and Eric Goldberg, 1995), FernGully: The Last Rainforest (Bill Kroyer, 1992), The Last Samurai (Edward Zwick, 2003) Vietnam Colony (Siddique Lal, 1992), other films, and numerous science-fiction stories and novels.

The critical response was moderately positive. Review aggregator web site Rotten Tomatoes determined the average rating to be 7.4 out of $10 .{ }^{242}$ Some pundits noted the film's left wing "attack on corporate culture, on mainstream religion and capitalism,"

\footnotetext{
${ }^{241}$ Internet Movie Database, "Avatar," Internet Movie Database, accessed January 20, 2015, http://www.imdb.com/title/tt0499549/?

${ }^{242}$ Rotten Tomatoes, "Avatar," Rotten Tomatoes, accessed November 6, 2014, http://www.rottentomatoes.com/m/avatar/.
} 
while others noted the film's racism and colonialism through the casting, characters, the use of the noble savage, and the patronizing "rescue by the white man." ${ }^{243}$ The Vatican newspaper added a third perspective, noting that the film "gets bogged down by a spiritualism linked to the worship of nature."244

Apart from possible thematic concerns, there are other elements of interest to film classification agencies. Avatar features nearly naked humanoid aliens, a very discreet sex scene, and significant amounts of violence. During a climactic battle many humans and aliens are killed by guns, spears, knives, and arrows; some are blown up, crushed, or attacked by large animals. There are also some brutal fighting scenes, particularly the predictable mano a mano between the hero and the villain. Despite being set over a hundred years in the future, the humans speak current English, including idioms and expletives.

The film opened in December of 2009, in 2D, 3D and IMAX formats, and quickly set box office records. The impressive visuals, conventional story, and modest unfocused controversies all contributed to film's attraction. Nominated for nine Academy awards, it won three relatively minor ones, but did win Best Picture and Best Director at the Golden Globes. In August of 2010, the film was re-released as a Special Edition with approximately nine minutes of additional footage. DVD and Blu-ray versions include an

\footnotetext{
${ }^{243}$ Daniel Franklin, "Avatar: The Plot, the Controversy, the Irony," Encyclopedia Britannica, accessed January 20, 2015, http://www.britannica.com/blogs/2010/01/avatar-the-plot-the-controversy-the-irony.; Will Heaven, "James Cameron's Avatar Is a Stylish Film Marred by Its Racist Subtext," News - Telegraph Blogs, December 22, 2009, http://blogs.telegraph.co.uk/news/willheaven/100020488/james-cameronsavatar-is-a-stylish-film-marred-by-its-racist-subtext/.

${ }^{244}$ Joe Cramer, "'Avatar' Draws Controversy from the Vatican," The Villanovan, accessed January 5, 2015, http://www.villanovan.com/news/view.php/145596/Avatar-draws-controversy-from-the-Vatica.
} 
Extended Edition, with 7 more minutes of footage. Sequels are planned for release in 2016, 2017, and 2018..$^{245}$

\subsection{Rating Avatar}

The MPAA rated Avatar PG-13, "for intense epic battle sequences and warfare, sensuality, language and some smoking." In Canada, the rating was 14A from British Columbia, PG from the other English agencies, and G in Quebec, with a variety of warnings. None of the classifications changed for the re-release or DVD. Some agencies added a second entry, others simply updated the time, and Nova Scotia did not indicate any changes. See table 4 for details of the ratings in Canada. The CHVRS rating for the film is not provided on that site, and although the rating is determined from the ratings of the English agencies, it is $14 \mathrm{~A}$, higher than expected since four out of five agencies rates the film PG. ${ }^{246}$

The MPAA's PG-13 classification means "Some material may be inappropriate for children under 13." Quebec, Manitoba, and Alberta all used the lower G or PG rating, but noted "Not Recommended for Young Children." Nova Scotia and Ontario's PG rating did not include any advisory about young children, but warned of Violence and Language. Ontario also felt it necessary to warn of "3D effects," presumably concerned about the potential for nausea.

\footnotetext{
${ }^{245}$ Internet Movie Database, "Avatar."

${ }^{246}$ The CHRVS rating was obtained from a DVD of the film, purchased in Quebec. Appendix A shows the appropriate spindle label and box label, as well as the Canadian packaging which confusingly displays the CHVRS 14A and Quebec G right next to each other. The rating is not available on the CHRVS web site. There is no explanation for its absence, and the response to an inquiry was to refer to the provincial sites for ratings information. It is not clear if CHRVS uses a strict numerical average or weights the different agency ratings.
} 
British Columbia's 14A classification is a clear message that the film is not recommended for young children, and like all the other agencies except Quebec, the rating warns of violence. The MPAA rating does not mention violence; instead, it notes "intense epic battle sequences and warfare." This is less stark than violence, and the modifiers 'intense' and particularly 'epic' generally have a positive connotation. The MPAA is the only agency to mention smoking in the classification, though Ontario and Alberta mention this in the additional online details. Alberta also provides some thematic issues raised by the film. British Columbia is the only agency to state the instances of swearing, and detail the violence.

For the classification agencies, reviewing a mainstream Hollywood film is a relatively simple matter of determining the classification. The days of requesting eliminations are long gone. British Columbia, Ontario, Quebec, and Nova Scotia all still have the legal authority to ban or refuse to classify films, but recent instances are very rare, and do not involve mainstream Hollywood films. Dialogue once muted is now merely observed to determine the rating and content advisories. However, the film makers may choose to make pre-production or production cuts during discussions with the MPAA, or in the hopes of getting a specific rating, and that appears to have been the case with Avatar.

After Avatar was released, James Cameron claimed he removed a sex act specific to alien anatomy, in order to avoid an R rating and obtain the desired PG-13. ${ }^{247}$ The aliens have long hair braids that terminate in sheathed tendrils, the biological equivalent

\footnotetext{
${ }^{247}$ Breeanna Hare, "'Avatar' Sex Scene on DVD?," accessed January 20, 2015, http://marquee.blogs.cnn.com/2010/01/06/avatar-sex-scene-on-dvd/.
} 
of a USB port. The sexual aspect of the tendrils is established early: The lead male is exploring his artificial alien body, and when he touches the tendrils, a scientist tells him, "Don't play with that, you'll go blind." In the course of the film, the aliens connect their tendrils to animals and plants, in order to communicate and share information. When the lead male, in his artificial body, and a native female engage in what appears to be discreet conventional human mating, one might expect them to connect their tendrils, but they do not. The act is included in a script page made available online by Twentieth Century Fox after release and before re-release. Following some human kissing and cuddling:

She pulls him down until they are kneeling, facing each other on the faintly glowing moss.

Neytiri takes the end of her queue [braid] and raises it. Jake does the same, with trembling anticipation. The tendrils at the ends move with a life of their own, straining to be joined.

MACRO SHOT - The tendrils intertwine with gentle undulations.

Jake rocks with the direct contact between his nervous system and hers. The ultimate intimacy. ${ }^{248}$

The re-release version includes the connection of tendrils, but has the same MPAA and provincial ratings. It is possible that the original release film could have received a PG-13 with the connected tendrils, and Cameron's remarks may have been hype to promote the re-release and DVD versions. It is also possible that the success of the film made classifiers reluctant to consider changing the rating for a brief moment of alien sex, whereas when initially considered, the MPAA may have expressed concerns about the scene.

\footnotetext{
248 Brian Moylan, "The Avatar Na'vi Sex Scene Revealed," Gawker, accessed January 20, 2015, http://gawker.com/5445676/the-avatar-navi-sex-scene-revealed. Emphasis in original.
} 
Further cuts or edits may be made for distribution in Canada or other countries. Post production cuts to obtain a desired classification from a Canadian agency are not reported on their web sites or publicized by any party. It appears to be rare practice, but in Ontario, The Texas Chain Saw Massacre (2003) was cut by about two minutes, by the distributor, to obtain an $18 \mathrm{~A}$ rating instead of a Restricted rating. ${ }^{249}$ There do not appear to be any post-production cuts for Avatar in Canada.

Agencies in some countries provide information on cuts made. India's Central Board of Film Classification website provides a list of cuts and added disclaimers, such an anti-smoking banner during smoking scenes, in addition to the rating details. The web site for the British Board of Film Classification list cuts. It shows, for example, that The Hunger Games theatrical release was cut by seven seconds, by the distributor, in order to obtain a 12A rating (adult accompaniment required for children under twelve). ${ }^{250}$

In addition to not indicating cuts, the provincial agencies' web sites list only the current rating of a film, and do not indicate if the rating has been changed. This is reasonable, as generally people are interested in the current rating. However, the missing history of any ratings changes obscures the operations of the agencies. British Columbia posted appeal details in the mid-2000s, but no longer does this. Alberta includes notices of reclassifications of older films in subscriber emails. Ontario lists reclassifications, but this is displayed separately from the ratings information and decisions only indicate the new classification, which could be higher or lower than the original classification. ${ }^{251}$

\footnotetext{
${ }^{249}$ Personal communication with a member of the Ontario Board, September, 2005.

250 "The Hunger Games (2011)," British Board of Film Classification, accessed November 22, 2014, http://www.bbfc.co.uk/releases/hunger-games-2011.
} 
For Avatar, an early newspaper review revealed that the film was originally rated 14A by the Manitoba Film Classification Board. ${ }^{252}$ The distributor appealed, and the appeal board lowered the rating to PG and added the advisory notice "Not Recommended for Young Children." Though the date of the change is unknown, it was likely before or very soon after the release date. There is some evidence that Alberta or Ontario may also have lowered the rating on appeal. ${ }^{253}$ Since all or most of the theatrical releases took place with ratings after appeals, the initial ratings were not a major factor at the time of distribution.

\subsection{Canada / USA Comparison}

The ratings for Avatar from Canadian agencies are, on the whole, more liberal. British Columbia's 14A is more restrictive than the MPAA's PG-13, but the Canadian average of PG is similar to the MPAA's PG, a lower classification. The average might

\footnotetext{
${ }^{251}$ Most appeals are launched by distributors to obtain lower ratings, and for some agencies this is the only type of appeal. Some agencies can use the appeal process to reconsider ratings if there are public complains. For example, The Hunger Games was originally rated PG in Ontario and British Columbia, G in Quebec, and 14A in Nova Scotia, Manitoba, and Alberta. Five weeks after the release, the Ontario Film Review Board reconsidered the film in light of public complaints, and reclassified it 14A.

${ }^{252}$ Randall King, "FP Critic's Eyes See Avatar in Different, Spectacular Light," Winnipeg Free Press, accessed January 20, 2015, http://www.winnipegfreepress.com/arts-and-life/entertainment/movies/fpcritics-eyes-see-avatar--in-different-spectacular-light-79882357.html.; An inquiry to the Board verified the ratings change. Personal communication with a member of the Board, November 2015.

${ }^{253}$ The web site Parent Previews incorrectly shows that Avatar has a 14A rating in Alberta, which may be an out of date entry if Alberta originally gave that rating and then lowered it. The site also shows the out of date 14A entry for Manitoba, however it shows PG for Ontario. Parent Previews, "Avatar," Parent Previews, accessed January 20, 1015, http://parentpreviews.com/movie-reviews/avatar.

The Avatar listing at the Ontario Film Review Board site shows the time as 182 minutes, and the classification date as Dec 10, 2009. One of these is incorrect. The time refers to the Extended DVD version, released much later. It is possible that the time and rating were updated for the later DVD, and the classification date refers to the original classification. Neither Ontario nor Alberta has been able to provide additional information about Avatar's classification. If either Ontario or Alberta started with a 14A rating, that might explain why the CHRVS indicates a 14A rating on the package. As ratings can change, they may become out of sync with printed packaging.
} 
have been higher if the appeal(s) had not been successful, but since they were successful, this is a moot point.

Nova Scotia and Ontario both applied a PG rating, and did not use the "Not Recommended for Young Children" advisory. Quebec, Ontario and Manitoba did use that advisory with the PG rating (G in Quebec), but the use of PG instead of 14A makes that a suggestion, not a restriction. Manitoba's PG classification specifically advises "Most suitable for mature viewers over 12 ," but the general understanding of this is evidentially low due to the use of the "not recommended for young children advisory." PG with an advisory about young children has essentially the same meaning as MPAA's PG-13, but advisories are less noticeable and carry less weight than the classification.

\subsection{Encoding and Decoding Ratings}

The similarities between the American and Canadian ratings systems can cause confusion. Canadian film viewers are exposed to MPAA ratings through American TV commercials, online trailers, American reviews online and reprinted in Canadian newspapers, and home video versions of films. Both systems have G and PG, but the next levels up have different names (14A and PG-13). The Restricted classification is used in both systems, but for different levels. Viewers' understandings of the ratings are also affected by the more generic issues of understanding the meanings in any mass communication. Semiotic studies are applicable to this concern, as well as the process of assigning classifications.

In the language of semiotics, a film is a text, and creating a text involves encoding meaning. Stuart Hall's analysis of encoding and decoding in mass communication (in his 
example, television, but applicable to films), explains that encoding occurs when the text is produced, and decoding occurs when the viewer receives the text. ${ }^{254}$ As the circumstances of reception are different than the circumstance of production, the viewer may not receive the same meaning as that which was encoded. The viewer may consciously or unconsciously accept the intended meaning, the viewer may negotiate the intended meaning, accepting some aspects and rejecting others, or the viewer may reject the intended meaning. For example, a viewer may find a raunchy comedy consistently hilarious (accept), a viewer may find the film amusing overall despite some offensive humour (negotiate), or a viewer may find the film boring and dreary, and eventually leave and ask for a refund (reject).

A mainstream Hollywood film's MPAA rating is part of the circumstances of production. It shapes the text, and becomes part of the text. A rating provides some information about the film, and provides an assurance that an authority, the government in Canada, has reviewed the film and determined the age appropriateness of the film. That information and assurance becomes part of the film.

Viewers may accept, negotiate, or reject the rating. The existence of alternate classification systems suggests there is ongoing rejection in some cases. Part of negotiating the rating may be reading a caution as a promise. Avatar's ratings comment "intense epic battle sequences," may be decoded as a promise rather than a warning. Similarly, the PG-13 rating promises teen viewers more action and more explicitness than a PG or G rating.

${ }^{254}$ Hall, "Encoding/Decoding." 
Parents may accept the intended reading of a PG-13 rating (I need to consider if this film is appropriate for my children), negotiate the reading (this may not be appropriate for some children, but mine will be fine) or reject the reading (my kids aren't scared of anything, I don't care what the raters say; or my teens won't see this as there is too much sex in PG-13 films).

The assigning of ratings is itself a process of decoding and encoding. Avatar's film makers included, or encoded, amounts of sensuality and violence they considered appropriate for a PG-13 classification. When the classifiers viewed Avatar, they decoded the theme, and the presence and amount of various elements such as sensuality and violence. Their backgrounds, movie knowledge, and roles as parents advising parents may cause them to decode the elements as greater or less than that intended by the film makers. The MPAA decoded Avatar as being consistent with the PG-13 classification.

Given the close relationship between Hollywood studios and the MPAA, and the advance review of material, the classifiers are likely to accept the encoded theme and level of elements as intended by the film makers. The circumstances of production and viewing are similar, especially at the appeal level, where representatives of the film industry view a product of the film industry.

When a film comes to Canada, the agencies may or may not be aware of the MPAA classification. The agencies decode the film in circumstances different from the MPAA, and from each other. They are more removed from the industry, and depending on the agency, view in different circumstances depending on whether the classifiers are full time employees or part time board members. The former see more films, while the latter are arguably more representative of community concerns. In addition, as previously 
noted, except in the case of Alberta, classifiers in Canada view a wider range of material than MPAA classifiers. Agency differences are not just from serving "a different class of people" but from their different scopes. ${ }^{255}$

Classifiers attempt to decode objectively, in the belief that this results in an accurate understanding of the message. The Ontario Guidelines state:

Ask yourself: Did you actually see the murderer slice the victim's throat with the knife? Or did you just see him threaten the victim with the knife, hear the screams, and see the splatter of blood? Did you actually see the couple having sex? Or did you just see them rolling around half naked beneath a sheet? Hollywood is superb at implying action that is not really there and making us believe we saw things we didn't. In order to evaluate the elements in a film it is very important to be aware of what you actually see on the screen." 256

When following these guidelines, the classifiers are choosing to negotiate the meaning of the imagery, with the goal of creating a clearly encoded message about the content. The meaning is that a person's throat was slashed, but it was not shown, just suggested. Viewers not following such guidelines decode the meaning of the imagery under different circumstances from the classifiers. These viewers may reject the classification as inaccurate, and decode the imagery to be what it implied, the throat being slashed, and not what was literally shown. Alternately, viewers may negotiate a film's message about horrors of violence as being less significant than encoded, on the grounds that the classification is merely PG-13, and therefore the violence is not that bad.

Despite attempts to be objective, decoding elements remains primarily subjective and subject to the circumstances of viewing. When classifying the violence element,

\footnotetext{
${ }^{255}$ Dean, Censored!, 47.

${ }^{256}$ Ontario Film Review Board, "Classifying Mainstream Films," 7. Emphasis in original.
} 
considerations according to the Ontario Guidelines include "how unnerved you were by the act" and whether the violence has "positive effect or dramatic purpose" or if it is a "cheap special effect."257

Canadian classifiers encode a film with broader intentions than their MPAA counterparts. The MPAA ratings are intended to provide "parents the information they need to decide whether a film is appropriate for their family." 258 The Canadian agencies generally acknowledge families and children, but note that they classify films on behalf of all viewers. For example, Alberta notes that ratings allow "film patrons make informed decisions about what is appropriate viewing for themselves and their families." 259 Nova Scotia states "Films and Videos are classified to help you decide if a particular movie is suitable for you and your family."

The concern for everyone might be considered more patronizing than the American approach of focusing on parents, but it is also more respectful of children (and their parents), as they are not singled out as in need of protection or guidance. While there are potentially more restrictions on films children can see in Canada, due to the 14A and $16+$ classifications, in practice there are fewer restrictions due to the more liberal ratings. ${ }^{260}$

${ }^{257}$ Ibid., 11.

258 "CARA." Emphasis added.

${ }^{259}$ Government of Alberta, "Alberta Film Ratings."; Province of Nova Scotia, "Access Nova Scotia - Film and Video," Service Nova Scotia, accessed January 19, 2015, http://www.novascotia.ca/sns/access/alcoholgaming/theatres-amusements.asp. Emphasis added.

${ }^{260}$ Restrictive film ratings prevent children from seeing films, or require them to attend with their parents. This could be considered a children's right issue, though advocates would probably agree that the right to view films is low on the list of concerns. However, the position of the USA on children's rights is worth noting. Every country in the world except the USA, Somalia, and South Sudan have ratified the United Nations Convention on the Rights of the Child (UNCRC). Somalia and South Sudan have both taken steps 
Film ratings are an attempt to decode the text, and subject to all the hazards of determining meaning in any mass communication. The assigned rating then becomes part of the text, further complicating the decoding by the final viewer.

\subsection{Conclusion}

Avatar is a typical mainstream Hollywood film. The story is conventional, the effects impressive, and the moral lessons blunt and popular. Questions about subtle issues of colonialism and sexism are of no concern to classifiers, who considered the portrayals of sexuality and violence, and the gratuitous swearing. The film makers went to the trouble of inventing a language for the natives, but relied on contemporary expletives, perhaps in part to ensure a PG-13, a sweet spot for Hollywood films.

Like most films, the rating in Canada was less restrictive. Canadian agencies were concerned about violence, and gave harsher warnings than the MPAA, but on average rated Avatar PG. With no direct equivalent to PG-13, the Canadian agencies had the choice of the higher 14A, or the lower PG. Except for British Columbia, they chose the lower PG, but in at least one case, only after appeal. Lack of information about appeals and possible cuts to rated films is probably not a deliberate attempt to obscure the operations of the agencies. It most likely reflects a desire to keep costs low and not present possibly confusing information. The end result is still obscured operations, and agencies in other countries are able to provide this information. 
Determining and communicating the ratings requires decoding and encoding the meanings in a film. The circumstances of viewing a Hollywood film by members of the MPAA are different in several respects from the circumstances of viewing a film by members of Canadian agencies, and there are further differences among the Canadian agencies. These differences include histories, operations, and being part of the industry, or part of the government. 
Table 4: Avatar Classifications, Advisories, and other information

\begin{tabular}{|c|c|c|c|}
\hline Agency & Rating & Advisory & Additional Online Material \\
\hline NS & PG & Violence, Language May Offend & 161 minutes \\
\hline QC & $\mathrm{G}$ & $\begin{array}{l}\text { Not recommended for young } \\
\text { children }\end{array}$ & $\begin{array}{l}171 \text { minutes } \\
\text { Rating applies to } 35 \mathrm{~mm} \text { film, DVD, Imax, digital, VHS } \\
\text { Reason for Ranking: The story, set in a strange and fabulous land where the } \\
\text { animals and plants are rendered with stunning visual effects, contains } \\
\text { moments of tension and fighting armies. } \\
\text { Synopsis: In } 2154 \text {, on a planet surveyed by humans, a young soldier agrees to } \\
\text { use the artificial body of a native to establish relations with that intelligent } \\
\text { species, living in harmony with their environment. * }\end{array}$ \\
\hline ON & PG & $\begin{array}{l}\text { Violence, Language May Offend, } \\
\text { 3D effects }\end{array}$ & $\begin{array}{l}182 \text { minutes } \\
\text { Detailed observations: } \\
\text { Use of expletives } \\
\text { Mild sexual references } \\
\text { Scenes that may cause a child brief anxiety, or fear } \\
\text { Embracing and kissing } \\
\text { Mild sexual innuendo } \\
\text { Tobacco use } \\
\text { Restrained portrayals of non-graphic violence }\end{array}$ \\
\hline
\end{tabular}




\begin{tabular}{|c|c|c|c|}
\hline MB & PG & $\begin{array}{l}\text { Not Recommended For Young } \\
\text { Children, Violence }\end{array}$ & $\begin{array}{l}162 \text { minutes** } \\
\text { Infrequent mild profanity } \\
\text { Frequent portrayals of non-graphic violence } \\
\text { Frequent and/or prolonged portrayals of graphic violence which may be } \\
\text { characterized by extreme brutality, extreme bloodletting and extreme tissue } \\
\text { damage. } \\
\text { Occasional disturbing/offensive scenes }\end{array}$ \\
\hline $\mathbf{A B}$ & PG & $\begin{array}{l}\text { Violence, Not Recommended For } \\
\text { Young Children }\end{array}$ & $\begin{array}{l}162 \text { minutes** } \\
\text { Synopsis: } \\
\text { Science Fiction/Adventure. While Earth military forces plan an invasion of } \\
\text { the planet Pandora to extract its precious natural resources, a parallel } \\
\text { scientific program places humans into alien bodies called 'avatars' in order to } \\
\text { communicate with the indigenous people. } \\
\text { Content Elements: } \\
\text { Infrequent use of scatological slang, profanity and mild cursing } \\
\text { Frequent creature and weapons violence - some blood and impact } \\
\text { Frequent portrayals of smoking } \\
\text { Thematic Elements: } \\
\text { Creating understanding } \\
\text { The corruption of power } \\
\text { The relationship between humans and nature } \\
\text { Classification Rationale: } \\
\text { Rated PG for frequent violence in a fantasy context. }\end{array}$ \\
\hline
\end{tabular}




\begin{tabular}{|l|l|l|l|}
\hline BC & $14 \mathrm{~A}$ & Violence & $\begin{array}{l}162 \text { minutes** } \\
\text { The following were determinative to the classification decision: } \\
\text { Several scenes of violence depicting fighting, stabbing, shooting, impalement } \\
\text { and explosion. } \\
\text { Classifiers also noted the following: } \\
\text { Approximately 21 instances of coarse language. }\end{array}$ \\
\hline MPAA & PG-13 & $\begin{array}{l}\text { Rated PG-13 for intense epic battle } \\
\text { sequences and warfare, sensuality, } \\
\text { language and some smoking. }\end{array}$ & $* *$ \\
\hline
\end{tabular}

* Translated from the French original: L'histoire, qui se déroule dans un univers étrange et fabuleux où la faune et la flore prennent vie grâce à des effets visuels époustouflants, contient des moments de tension et des affrontements guerriers. En 2154 , sur une planète prospectée par les Terriens, un jeune soldat accepte de s'incarner dans le corps d'un indigène créé génétiquement afin d'établir des relations avec cette espèce intelligente vivant en harmonie avec son environnement.

** There is a separate listing for the longer Special Edition, but the rating, advisories, and additional online information is identical (except in the case of British Columbia, where the Special Edition had "approximately 22" instances of coarse language.) 


\section{Case Study: Pirates}

Selecting the sex film equivalent of Avatar for a case study is complicated by the absence of public exhibition, reviews, and box office data for sex films. Despite this, Pirates stands out for several reasons. Pirates was a joint production between two of the larger and more established companies, Digital Playground and Adam \& Eve, and the filmmakers claim the budget was over a million dollars, an unusually high figure in that industry. ${ }^{261}$ In a throwback to the marketing practices of home video in the 1980 s, it was initially released for sale only, at prices up to $\$ 70$ (more than double other features). ${ }^{262}$ The initial release was a three disc edition: Standard DVD, High Definition DVD, and a disc for special features. The producers claimed to have sold 100,000 copies soon after release, in an industry where 5,000 sales is common. ${ }^{263}$ Pirates received numerous top awards from three different industry associations.

In a rare step, the film makers obtained an MPAA R classification for an edited version of Pirates. The original film is 129 minutes long, and the $\mathrm{R}$ rated version, which removes all of the explicit sexual activity and adds a small amount of non-explicit sexual activity, is a modest 80 minutes. An R classification allows sales and rentals of Pirates at mass market retailers. In other examples of mainstream marketing, Pirates opened the

${ }^{261}$ Daniel McGinn, "XXX Blue, Spending Green," Newsweek, November 27, 2005, http://www.newsweek.com/xxx-blue-spending-green-115291. Though unusually high, this may not be a record. Private Media Group released part one of Millionaire (Alessandro del Mar) in 2004, and claimed a budget of 1.9 million for the overall project. Jack Gillespie, "Private U.S.A. Sets Release Date For Multimillion-Dollar Feature, Millionaire," AVN - Business, accessed January 20, 2015, http://business.avn.com/articles/video/Private-U-S-A-Sets-Release-Date-For-Multimillion-Dollar-FeatureMillionaire-40243.html.

${ }^{262}$ The author attempted to view the film for a 2006 paper, but could not rent it or justify the purchase price.

${ }^{263}$ McGinn, "XXX Blue, Spending Green." 
2006 Great Lakes Film Festival in Erie, Pennsylvania, and the filmmakers released a soundtrack album. Pirates continues to be a strong seller almost ten years after release, and was followed by a sequel, Pirates II: Stagnetti's Revenge (Joone, 2008), that was also released in an $\mathrm{R}$ rated version. ${ }^{264}$

While Avatar's popularity may be due to how well it delivered the typical elements of a mainstream film, Pirates' popularity is due at least in part to how well it avoided some of the typical elements of a sex film. Conscious of Paasonen and Saarenmaa's concern that academic study of adult sex films canonize a small group of films that do not represent the industry, it should stressed that Pirates represents the aspirations of the industry, or one aspect of the industry, the big-budget narrative feature film, rather than the industry as a whole.

Pirates is a lightly comic tale of two groups: Pirates searching for a mystical treasure, and sailors searching for the pirates. The plot is thoroughly mainstream, but in the course of the story there are ten sexually explicit and narratively integrated sex scenes. The quality of dialogue and performances varies widely, and like many period films, the appearance of the performers reflects contemporary and genre standards of attractiveness more than historical authenticity. The well decorated and populated sets, and special effects including 3D animation and green screen work, are on a par with straight to DVD productions such as films from The Asylum Group (Transmorphers, Leigh Scott, 2007; Sharknado, Anthony C. Ferrante, 2013).

\footnotetext{
${ }^{264}$ A Canadian online retailer of adult sex products lists Pirates and its sequel first and third on a list of DVD best sellers. "VideoCanada.com DVD Movies," accessed January 7, 2015, http://www.videocanada.com/catalog2/index.php?cPath=1.
} 
In two scenes the men are anachronistically and discreetly using condoms. This behind the scenes glimpse breaks the reality effect of the film's narrative. It reinforces the generic spectacle of sex films, watching people have sex, and brings to mind some of the social concerns about sex film production. The break is similar to spotting parachutes under the bulky clothing of aerial stunt performers, or seeing a pneumatic cannon during a car stunt, in mainstream films.

Shipboard on deck sequences, all non-sexual, were filmed on the tall ship Bounty at the Pier in St. Petersburg, Florida. The producers of Pirates misrepresented their film as a PG-13 production to obtain the location, an indication of the authority of ratings, and the preference for PG-13. Once filming began, some of the performers were recognized as adult film actors. The Pier authorities did not have any contractual reason to cancel the rental. Instead, they obtained a promise to not mention the St. Petersburg Pier, city, or the Bounty in any credits or materials associated with the film. ${ }^{265}$

Pirates is a parody of a popular mainstream feature, Pirates of the Caribbean: The Curse of the Black Pearl (Gore Verbinski, 2003). The cover designs reference Pirates of the Caribbean, with similar layout, imagery, and colouring, particularly of the $\mathrm{R}$ rated version (see figures 1, 2 and 3). Plot elements and aspects such as the music and ship also reference Pirates of the Caribbean. There are fights with a skeleton army, as in Pirates of the Caribbean, though the sequence is more reminiscent of Jason and the Argonauts (Don Chaffey, 1963) and there are also references to the original Star Trek TV series. Sexually explicit parodies of popular entertainments are hundreds of years old, and

\footnotetext{
${ }^{265}$ Jay Cridlin, "Yo Ho, Yo Ho ... Oh No!" Tampa Bay Times, January 18, 2006, http://www.sptimes.com/2006/01/18/Tampabay/Yo_ho_yo_ho_oh_no.shtml.
} 
are common idea for feature length sex films, though the degree of parody and faithfulness to the original varies. 


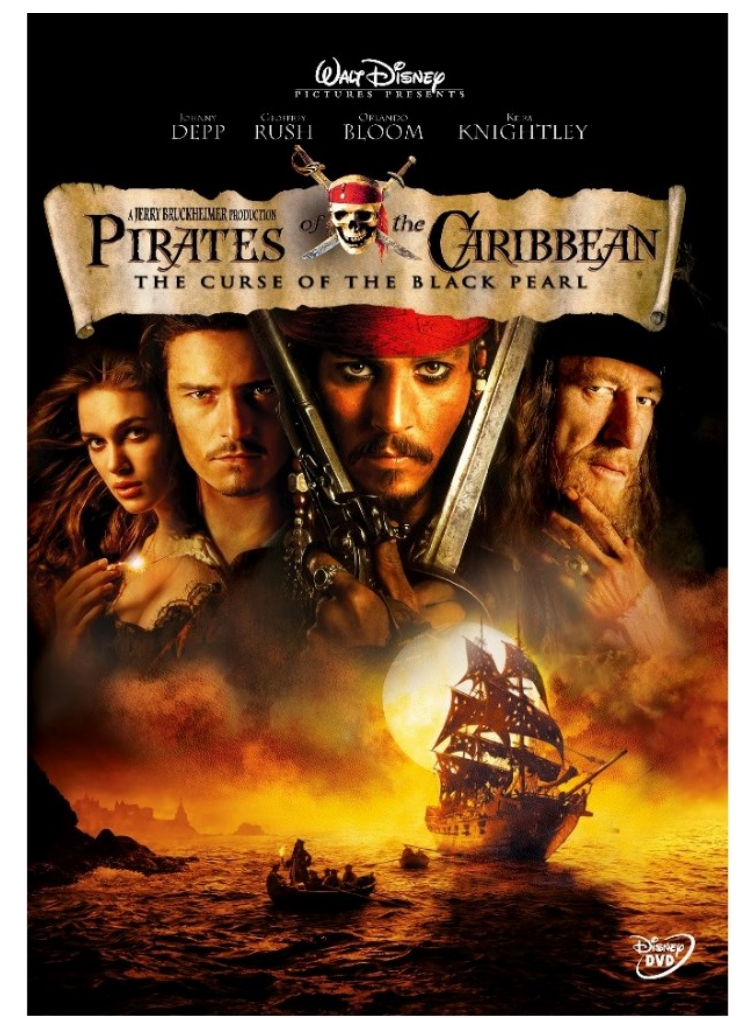

Figure 1 - Pirates of the Caribbean

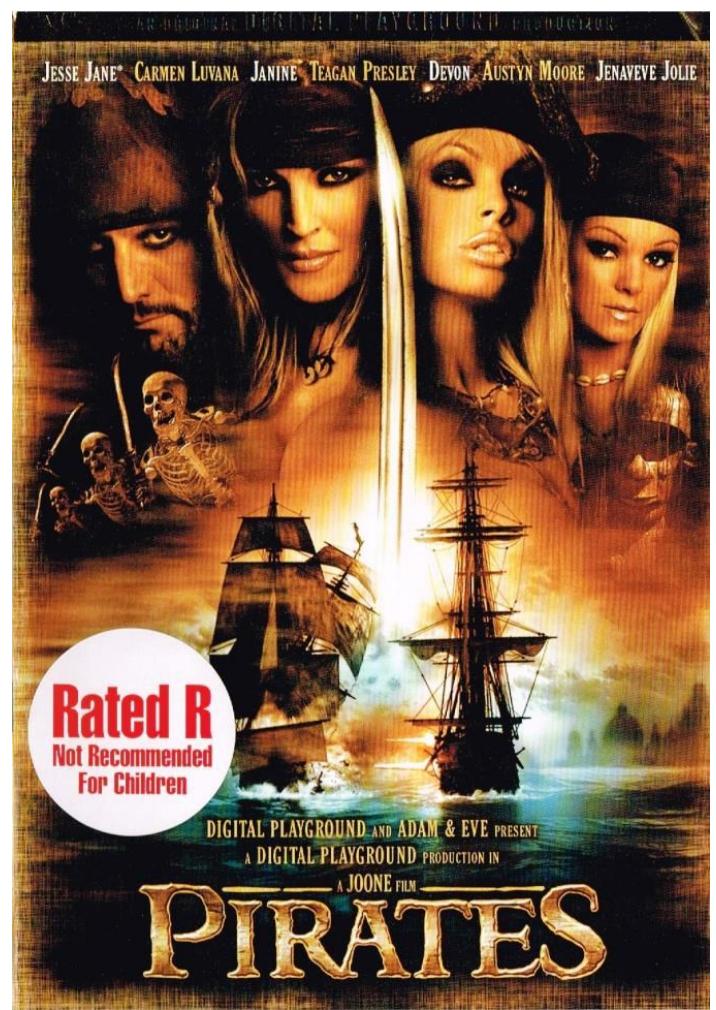

Figure 2 - Pirates, R Rated Version Rating label added by retailer

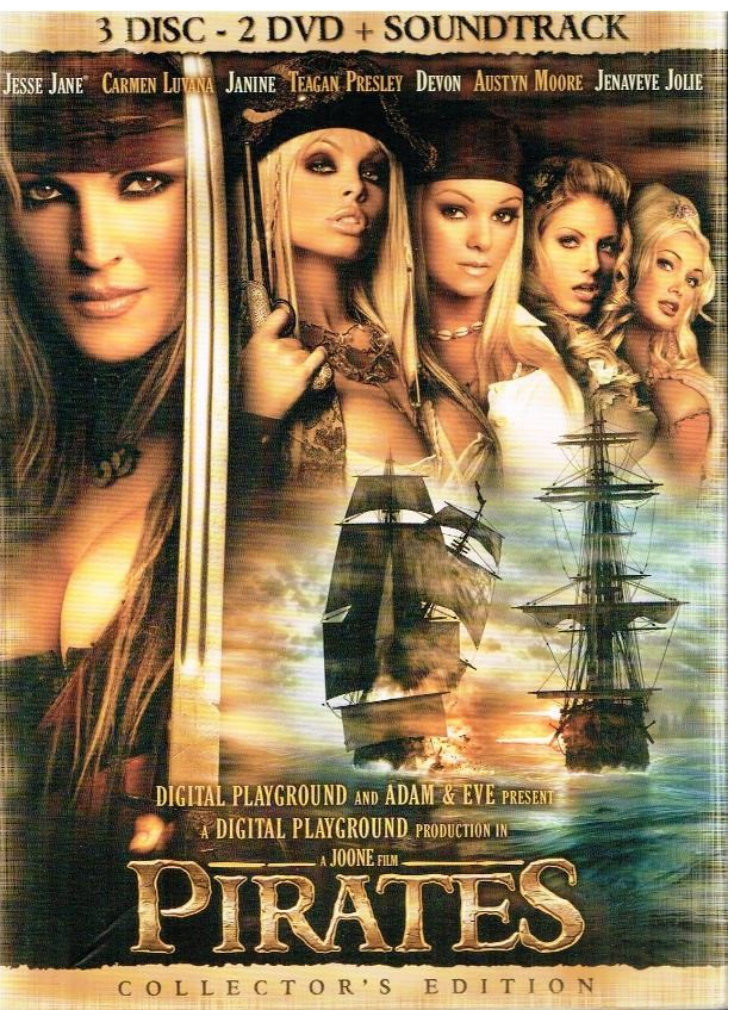

Figure 3 - Pirates, Explicit Version 


\subsection{Rating Pirates in the United States}

Pirates is not from an MPAA member company, so it can be distributed in the United States without any rating. As an unrated film, it faces restrictions on advertising and exhibition. Chain theatres will not show it, and major retailers will not carry the DVD. The same restrictions would apply if the film makers had obtained an NC-17 rating. The edited Restricted $(\mathrm{R})$ version does not face these obstacles.

The MPAA R rating explanation is "strong sexual content, nudity and language." There is also some violence, but it is muted even in the original version. For example, several characters' throats are slit in the context of a pirate attack, but the action is bloodless, and the killings are carefully shot to suggest more than they show.

The $\mathrm{R}$ rated version is partly a marketing tactic promoting the uncut adult sex version, and partly an additional source of revenue in itself. By obtaining a Restricted rating and making the film available through mainstream retailers and web sites, the film gains substantial exposure, and legitimacy as a film with more to offer than sex scenes. The film makers benefit from increased sales, particularly among viewers who purchase the $\mathrm{R}$ rated version, and then seek out the uncut version. This is similar to the mainstream tactic of releasing a film with an $\mathrm{R}$ rating for theatres, then releasing an unrated version with more explicit material for home video.

Prior to 1990, Pirates could have rated itself X. NC-17 cannot be self-applied, but it continues to be associated with adult sex films and is rarely used. Pirates could have obtained an $\mathrm{NC}-17$ rating with fewer cuts, but the decision to get an $\mathrm{R}$ rating is a clear 
example that R conveys a legitimacy that NC-17 does not. ${ }^{266}$ Given the ever present possibility of obscenity charges for any portrayal of explicit sex, and the ready availability of sexually explicit material online, appealing to legitimacy and consumer interest through narrative, sets, costumes, and an $\mathrm{R}$ rated version is a reasonable approach to making adult sex films.

\subsection{Rating Pirates in Canada}

The different versions of Pirates have different distributors, and it appears not all jurisdictions classified both versions. ${ }^{267}$ As there was no theatrical release, both versions are exempt from rating in Alberta. The edited version, classified as Restricted by the MPAA, is exempt from rating in British Columbia.

Manitoba rated the edited version Restricted (no admission under 18), with advisories of Nudity and Explicit Sexual Content. This seems high and possibly incorrect, but the records correctly identify the distributor and running time. Nova Scotia rated the edited version 18A, with a Sexual Content advisory. Ontario and Quebec have no record of classifying the edited version. ${ }^{268}$ The Canadian Home Video Ratings System does not have an entry for the edited version (and does not include sex films).

\footnotetext{
${ }^{266}$ Shortbus (John Cameron Mitchell, 2006) has multiple explicit sex scenes and a Deep Throat era storyline of a woman searching for sexual fulfillment (and a USC 2257 disclaimer concerning the age records of the performers), but remains a mainstream film by its presentation of the material. The distributor, not an MPAA member, released it unrated with limited distribution to art house theatres, rather than obtain an NC-17 rating. Linda Williams claims this is an example of "timid" studios refusing to redeem the NC-17 rating. Screening Sex, 294-295.

${ }^{267}$ Attempts to confirm where the versions were submitted, with the distributors and the agencies, were not successful.

${ }^{268}$ Information on the rating of Pirates is from the agency websites, and, in the case of the approval of the uncut version in Manitoba, personal communication with a Board member, December 2014.
} 
The uncut version of Pirates has not been classified in Nova Scotia. ${ }^{269}$ It was approved as an adult sex film in Quebec, Ontario, and Manitoba. British Columbia approved the film, but only after one scene was removed. ${ }^{270}$

At issue was a sex scene between two women. It begins with one of the women snatched from the street and tied to a chair in a room full of armed men. While she protests and struggles, she is threatened by the other woman to perform or be hurt by the men, who are expecting to watch the two women have sex. The captive woman resists when her top is pulled off and her breasts are kissed. When she starts to receive oral sex, she stops struggling. After a reaction shot of the men, the captured woman is no longer tied up. Instead, she is lying on the floor, and engaged in enthusiastic sexual activity with the other woman while the men watch. At the end of the scene, the men praise the captured woman, and offer a generous and narratively significant payment.

British Columbia requested removal of the scene, on the grounds that it was coercive. The distributor appealed, noting that the film was clearly a fictional adventure, and that the captive woman was not forced to perform any sexual activity. The distributors also noted positive reviews of the film.

The agency responded that the sexual activity portrayed while the woman was tied up could be considered explicit, the character's subsequent enjoyment may have been

\footnotetext{
269 This does not appear to be a case of classification being bypassed. Adult video retailers in the Halifax area were unable to supply a copy of the film.

${ }^{270} \mathrm{BC}$ does not provide any information about the approval of adult sex films on their site, however in the past reconsideration letters responding to appeals were posted online. The information about the requested cut to Pirates was obtained from a reconsideration letter copied from the site several years ago. These letters and related correspondence are presumably still available, but obtaining them now requires costly searches under the Freedom of Information Act.
} 
"putting on a good show" as she was ordered to do, and that the level of reality and opinions of other viewers were not relevant to interpreting the Motion Picture Act.

Although the scene is coercive, and Ontario at least has been sensitive to coercion in the past, Ontario and the other agencies approved Pirates without requesting a cut. Considering the film as a whole, it is later made clear that the character truly enjoyed the activity, and she subsequently initiates two encounters with women. However, the captive woman suddenly enjoying sex is a long standing and troubling trope in sex films. ${ }^{271}$ The coercion remains in the edited version, but the subsequent enjoyed sexual activity is almost completely missing.

The next two sex scenes are even more coercive. In one, clearly played for humour, a love-struck woman offers to free a couple from a burning building if the man agrees to have sex with her first. In the other, a woman frustrated by lack of attention from her lover demands he perform oral sex on her. She threatens him with a knife, partially undresses, and says, "Now lick it!' The man asks "And if I don't?" The woman responds, "Then I will slit your throat and celebrate my new position as captain [of this ship]."272 This is obviously coercive, and while the man appears to enjoy the sex that follows, in context he may not have. The next day he cheerfully abandons the woman to attacking monsters (she survives). Neither British Columbia nor any other agency noted these scenes as coercive. The requested cut illustrates some of the challenges and double standards involved in approving adult sex films.

\footnotetext{
271 As Williams suggests, this trope may be a strategy to make visible female pleasure, and ultimately portray "the fundamental sameness of male and female pleasure." Hard Core, 50.

272 Joone, Pirates, 2005.
} 
The agencies that classified the explicit version do not provide any information about the content. One can safely assume an adult sex film has explicit sexual content, but there is no information about the range and intensity of sexual acts, the nature of the film, or any violence. The violence in Pirates is discreet, but it did not need to be. Sexual violence is never permitted in adult sex films, but other violence is, to the same degree as any other restricted film, and there are no warnings. For example, under Ontario guidelines, it is permissible for an adult sex film to portray a gory murder, even during a sex act, so long as the portrayal does not show the murder being committed for sexual pleasure. ${ }^{273}$

Films that are Restricted do not allow attendance by children, yet they still provide content advisories, presumably for the benefit of the adult viewers. Films that are classified as Adult Sex do not provide any content information for the benefit of the viewers. The reason for this difference is unknown.

An approved film may still be considered obscene by police or the courts. Given the lack of information, no assurance that the film is legal, and that the classification fees for (low volume) adult films are usually higher than for (high volume) mainstream films, the process of classification might be seen as little more than a sin tax.

There remains the benefit that by reviewing and approving adult sex films, the Canadian classifiers and agencies are able to classify films in the context of all film, not the context of MPAA reviewed "family friendly" films. In addition, unlike the United States where almost any adult sex film might be illegal, or permitted, the provincial agencies prior restraint of adult sex films helps limit the distribution of adult sex films

${ }^{273}$ Ontario Film Review Board, "Classifying Adult Sex Films," 2005, 8. 
that are considered harmful. While classifying adult sex films appears to help the agencies have a more liberal attitude towards all films, it does not follow that there is a greater tolerance for the content of sex films.

\section{Ideas and Images}

In mainstream films, no idea is off limits. Some ideas influence classification, but the main concern is the imagery. Ontario Board chair Mary Brown stated in 1985 that while censorship was the suppression of ideas, and not tolerable in a democracy, film classification was simply the suppression of images that had nothing to do with ideas. ${ }^{274}$ At that time the board very rarely approved explicit sex. ${ }^{275}$ Now that explicit sex is permitted, almost any image is allowed, but certain ideas are not. The imagery of explicit sex is allowed, but if it is presented as coercive, rape, incest, or involving children, including children over the age of consent, through something as innocuous as dialogue in a scene before the sexual activity, that same imagery becomes obscene. Adult sex films are often criticized for their lack of narrative and emphasis on spectacle, but wrong kind of narrative can make a film more likely to be banned. Lack of storylines and an emphasis on spectacle may in part result from the regulation of permitted story ideas, which only applies to adult sex films.

The current notions of obscenity accept that explicit imagery alone is not obscene: There must also be harm, which comes in the expression of ideas accompanying the imagery. What is rarely accepted is that ideas may be harmful in the absence of explicit

\footnotetext{
274 Perlmutter, "Going Public," 7-8.

${ }^{275}$ During the 1980s the Board had a special exception for "art" films, such as might be shown in an art gallery. This exception did not extend to films at film festivals.
} 
imagery. ${ }^{276}$ Critics of the ratings systems point out that the allowance of any idea in a mainstream film is not necessarily appropriate, particularly the portrayal of violence against women, which is more prevalent in mainstream films than in adult sex films. ${ }^{277}$ A pre-occupation with explicit imagery as a source of harm also allows "legal child pornography" to flourish. These are online services, in some cases operated by the same companies that host adult sex websites, which purchase and sell pictures and videos of pre-teen children modelling and posing. Studies have indicated such imagery, though not explicit, makes people more tolerant of child sexual abuse. ${ }^{278}$

The contradiction of unlimited imagery in adult sex films versus unlimited ideas in mainstream films is not generally an issue in the film classification process, but it occasionally causes problems with films near the border between mainstream and adult sex.

Baise-moi includes a sexually explicit rape scene, and other sexually explicit scenes. The Ontario Film Review Board banned the film on the grounds of too much explicit sex (imagery) for a mainstream film. The distributor resubmitted the film as an adult sex film, and it was banned again, this time for portraying sexual violence (idea) in

\footnotetext{
${ }^{276}$ This is similar to the position of anti-pornography writers such as York and LaRue, but rather than argue that certain ideas and less explicit portrayals are harmful, they argue that these should be considered pornography and regulated as such. The result is a circular argument: If it causes harm, it is pornography, and if it is pornography, it causes harm. A more effective approach might be to accept that not all pornography causes harm, and not all harm is caused by pornography.

${ }^{277}$ Yang and Linz, "Movie Ratings and the Content of Adult Videos." Waltman is among those who claim too much is permitted under ratings systems, but his position that some sexual acts are inherently degrading would be disputed by those opposed to establishing what appropriate pleasures are, such as Strossen.

Establishing what is harmful is challenging.

${ }^{278}$ Autumn Bangay, "Legal Child Pornography: The Influence of Sexually Provocative Images of Children on Adult Attitudes toward Child Sexual Abuse" (Honours Diss, Cape Breton University, 2006).
} 
an adult sex film. The film was eventually approved as mainstream film, with a Restricted rating, after cutting thirteen seconds of explicit sex. ${ }^{279}$

The Board subsequently modified its guidelines to allow unlimited sex in a mainstream feature, allowing films like Shortbus to be approved as mainstream films. Moving closer to allowing any image and any idea in a mainstream film is certainly liberal, but if the intention of limiting ideas in adult sex films is to reduce possible harm when these ideas are accompanied by explicit images, then the same standards should apply to mainstream films with explicit images.

\subsection{Conclusion}

Pirates is not a typical adult sex film, or even a typical adult sex narrative feature. The $\mathrm{R}$ rated version and the marketing capitalize on this difference. However, it remains a film that foregrounds explicit sexual activity for $40 \%$ of its running time. Like all adult sex films, it strives to make visible what is normally hidden, with regard to portrayals of sex, an approach made more obvious by its use of conventional cinematic approaches to the portrayal of violence and other elements.

Sex films in the United States face no restrictions other than the possibility of being found obscene. As any explicit activity might be considered obscene, depending on the undefined community, criminal charges are an ever present risk, but minimal for a film with relatively conventional sexual activity and the veneer of respectability. In Canada, sexually explicit activity alone is not enough to restrict the circulation of any film, but if combined the possibility of harm, restrictions are possible. This was the case

${ }^{279}$ Devine, My Tango with Porn. 
with Pirates, and thus it faced greater restrictions in Canada than in the United Sates. The inconsistency of recognizing harm within a film and among the agencies reflects social debates over what is and is not harmful. 


\section{Case Study: Hounddog}

Hounddog was written, directed and produced by Deborah Kampmeier. Kampmeier worked in theatre in New York for several years before making three short films, and then a feature film in 2003 . That film, Virgin, was made for $\$ 65,000$ and won awards at several film festivals. Hounddog, with a budget of 3.75 million, is her second film. Her third feature is in post-production. Kampmeier is interested in representations of female sexuality, and her film company is "dedicated to the development and production of films by and about women." 280

Hounddog premiered at the Sundance film festival in 2007 and later played at the Santa Barbara Film Festival. The following year, it opened in eleven theatres in the United States, and played a few months on two to five screens, grossing a modest $\$ 130,000$. In 2009 it played at Toronto's Female Eye Film Festival, and won Best of the Show. It was released on DVD in 2009.

Set in rural Alabama in the 1950s, Hounddog is a female coming of age drama that revolves around the rape of a twelve year old girl. The film's angle to distinguish this southern gothic tale is the girl's devotion to Elvis Presley, including singing songs in his style. She wants to get a ticket when he comes to town, and her desire to obtain one sets up a situation where she is raped. Her recovery is marked by her being able to cover a Presley song (itself a cover, as a character explains), in her own voice.

Like all coming of age dramas, the material is not appropriate for or of interest to very young children, but there is minimal controversial content apart from the rape. The

\footnotetext{
${ }^{280}$ Deborah Kampmeier, "Deborah Kampmeier," Full Moon Films, accessed December 20, 2014, http://fullmoonfilmsny.com/2010/12/deborah-kampmeier/.; Jon McCallum, Turning Darkness into Light: The Making of Hounddog, DVD (Empire Film Group, 2008).
} 
only nudity is a rear shot of man, in a non-sexual situation. Some adults are shown having sex, but the shot is just a few seconds of thrusting and no nudity. There are a couple of contextually appropriate racial slurs, and children and women are shown with bruises from abusive men. Children undress a few times, but they are not shown nude. During the brief rape sequence, the only images are the girl's face, one of her hands, and the scared reaction of a young boy.

As with the bruises, the action and violence of the rape are not directly shown, but the film is more disturbing for focusing on the circumstances and effects of sexual violence than the sexual violence itself. Hounddog's peaceful and positive resolution may also have been disturbing or at least unsatisfying to viewers expecting the violent resolution of the relatively common and nominally female empowering rape-revenge genre. $^{281}$

Critical response was mostly negative. Variety called it an "indigestible gumbo" with "nothing going for it commercially", but praised Dakota Fanning's performance as the girl. ${ }^{282}$ Box Office magazine stated: "Faulknerian in intent, Dukes of Hazzard-esque in execution, this Dixie-fried '50s period piece centers on the rape of a child (Dakota Fanning) and its traumatic aftermath. Aimless plotting and stock Southern characters combine to make this movie less than expected."283 Roger Ebert notes Dakota Fanning as

\footnotetext{
281 This is a rare but not new approach, and perhaps more common among female filmmakers or independent films. André Loiselle has written about the emphasis on consequences of rape rather than the spectacle of the act in the 1979 film Scream From Silence (Anne Claire Poirier). Mourir À Tue-Tête / A Scream from Silence, Cinetek Series (Wiltshire, England: Flicks Books, 2000), 16.

282 Todd McCarthy, "Hounddog," Variety, January 29, 2007.

283 Ray Greene, "Hounddog," Boxoffice 143, no. 3 (March 2007): 64-65.
} 
"the only good thing about Hounddog." 284 The non-commercial North American Review, from the University of Iowa, also praised Fanning's work, but called the film "affirming and poignant."285

The initial festival showing of the then unrated film generated a lot of interest due to the anticipated depiction of child rape. The Christian Film and Television Commission requested action against the film for child abuse, and the Catholic League for Religious and Civil Rights asked the U.S. Department of Justice to determine if child pornography laws were violated in making the movie. ${ }^{286}$

In North Carolina, where the film was shot, a Senator called for advance review of scripts before approving state tax benefits to films. Under state law, obscene films do not qualify for benefits, but he wanted to expand the restriction to include objectionable films such as Hounddog."287

The Utah Attorney General and a state children's justice official attended a screening to determine if there was a violation of state laws prohibiting simulated sex with a minor, "for purposes of prurient interest." After seeing the film, he said "There is absolutely no concern whatsoever about it violating child porn or sexual exploitation of minor statutes." He went on to note that the rape scene was "horrific," but "tastefully

\footnotetext{
${ }^{284}$ Roger Ebert, "'Hounddog' Movie Review \& Film Summary," accessed December 20, 2015 , http://www.rogerebert.com/reviews/hounddog-2008.

${ }^{285}$ Grant Tracey, "Crosscuts: Brief DVD Reviews - Hounddog," The North American Review 294, no. 5 (September 1, 2009): 45.

${ }^{286}$ Ben Winslow, "'Hounddog' Not Porn, A.G. Says," DeseretNews.com, January 26, 2007, http://www.deseretnews.com/article/655191420/Hounddog-not-porn-AG-says.html?pg=all.

${ }^{287}$ Mark Schreiner, "Republican: Scripts Need Reviewing," StarNewsOnline.com, accessed January 21, 2015, http://www.starnewsonline.com/article/20070126/NEWS/701260363.
} 
shot" and hoped the controversy would lead to necessary conversations about rape and abuse. "As long as we keep it taboo, victims won't report it and perpetrators won't be prosecuted." He also praised the positive message of the film: "...there is some hope in recovery for children who find themselves kind of lost and stuck in a world of abuse."288

\subsection{Hounddog and Independent Film Ratings in the USA}

The non-exploitive portrayal of the rape, and the praise from state officials, suggests it would be appropriate and even beneficial for teenagers to see the film. However, when the MPAA rated it for theatrical release, it was "Rated $\mathrm{R}$ for a disturbing sexual assault of a young girl, and brief sexuality." With this rating, no one under 17 could see the film without an adult. Viewers who might benefit most from the message could not choose to see the film on their own.

Trust (David Schwimmer, 2010), another small film dealing realistically and sensitively with the sexual assault of a teen (by a man she meets online), is also Restricted. On the other hand Warner Brothers' Suckerpunch (Zack Snyder, 2011), a violent fantasy film with a persistence theme of rape and sexual assault, received a PG-13 rating.

There are numerous complaints that the MPAA is more restrictive when rating independent films than when rating films from its members. ${ }^{289}$ Some of the complaints may be marketing tactics: A ratings controversy can generate news coverage, which is

${ }^{288}$ Winslow, "'Hounddog' Not Porn, A.G. Says."

${ }^{289}$ In addition to studies previously mentioned, the Oxford Dictionary of Film Studies entry for "Ratings System" notes that the MPAA privileges studio films over foreign and independent films, and provides some examples. Annette Kuhn and Guy Westwell, A Dictionary of Film Studies (Oxford: Oxford University Press, 2012), sec. Ratings System. 
free advertising. This is more valuable for budget challenged smaller films than for films from major studios. Kirby Dick's ratings documentary This Film is Not Yet Rated attacks the MPAA ratings system on several fronts, including more restrictive ratings for independent films. He uses split screens to show similar scenes in films from major studios and independents, with the former rated PG-13 and the latter rated R. ${ }^{290}$ Though effective, the scenes are out of context and the ratings may not have been based solely on the scenes shown. The documentary had some results, such as changes in MPAA roles, but nothing affecting the classification of independent films.

The best analysis of how the MPAA rates independent films is the study by Waguespack and Sorenson. This 2010 study analyzed the ratings and content of about 2400 movies, and found that, after controlling for content and other factors, films from independent filmmakers were consistency given more restrictive classifications than films from major studies. They note that among other factors, film classification is not a blind process: Classifiers know the actors, directors, and studio, and that may affect how they decode the elements of a film when determining the classification. According to Waguespack and Sorenson, "studies have time and again confirmed that, when evaluators know the identities of the individuals being evaluated, biases creep into the process with high-status participants (and usually men) receiving more favorable evaluations."291 In an effort to isolate the cause of different ratings, they compare MPAA ratings with ratings issued by the British Board of Film Classification, also operated by the film industry (but more isolated than the MPAA), and the Ontario and Australian boards, both

\footnotetext{
${ }^{290}$ Dick, This Film Is Not Yet Rated.

${ }^{291}$ Waguespack and Sorenson, "The Ratings Game," 543.
} 
run by government. Their analysis of the results indicates that industry boards are less likely to assign Restricted ratings (or the equivalent) than the government boards.

This suggests the lack of blind reviewing (if it could even be possible) is not necessarily the cause of rating discrepancies. Government reviewers are just as likely to recognize actors, directors and a studio as industry reviewers. This portion of the analysis is less confident than the general review of films within the United States. For example, it is not clear what ratings they used as equivalent to Restricted. They claim to have used the rating where adult accompaniment would be required, but for Ontario this could be 14A (lower than Restricted) or 18A (higher than Restricted). The main conclusion, that the MPAA is more restrictive with independent films, is well supported and consistent with substantial anecdotal data.

\subsection{Hounddog and Festival Film Ratings in Canada}

Festival films have a history of special treatment in Canada. There has long been an understanding that people attending film festivals can accept more challenging material than the general public. For example, despite the highly restrictive censorship of Quebec in the early 1960s, films at the Montreal Film Festival played uncut. ${ }^{292}$ The Stratford Film Festival in Ontario, launched in 1964, was exempt from film classification. At some times, and in some jurisdictions, festival films have faced restrictions. In 1965, when the Calgary Film Society wanted to show Woman in the Dunes, the Board requested a cut of 120 feet. The Society appealed, and the Appeal Board requested a cut

${ }^{292}$ Dean, Censored!, 160. 
of 739 feet. ${ }^{293}$ As noted in chapter three, this film was approved uncut for a theatrical showing in Ontario, and it also played uncut in Quebec.

In 1975, Ontario started requiring classification and approval of all films at film festivals. The Board and the Toronto International Film Festival routinely fought over censorship of festival films, but both parties understood that this was a publicity game. In a 1985 interview, the Board chair said "Every year the Festival seems to introduce a film that we have no choice about and it gets them a lot of publicity." ${ }^{294}$ The festival director disagreed with this "totally inappropriate statement" and declared "no film has ever been selected for presentation at the festival based on the assumption that it will contravene the guidelines established by the Ontario Film Review Board." 295 Some years later another festival director acknowledged that "The Ontario Censor Board was a wonderful target for us to posture with in the press, and what seemed like a disadvantage worked in our favour as we occasionally posted 'Screening Cancelled by order of the Ontario Censor Board' at our theatres. This actually made it easier for the banned films to get publicity and to arrange private screenings for buyers." 296

Ontario stopped requiring classification of festival films in 1988, on the condition that admission be limited to adults. Alberta no longer cuts or bans any films, and festival films are now exempt from classification in that province and in Quebec. Most films in Saskatchewan are rated by British Columbia, but festival film ratings are managed by the

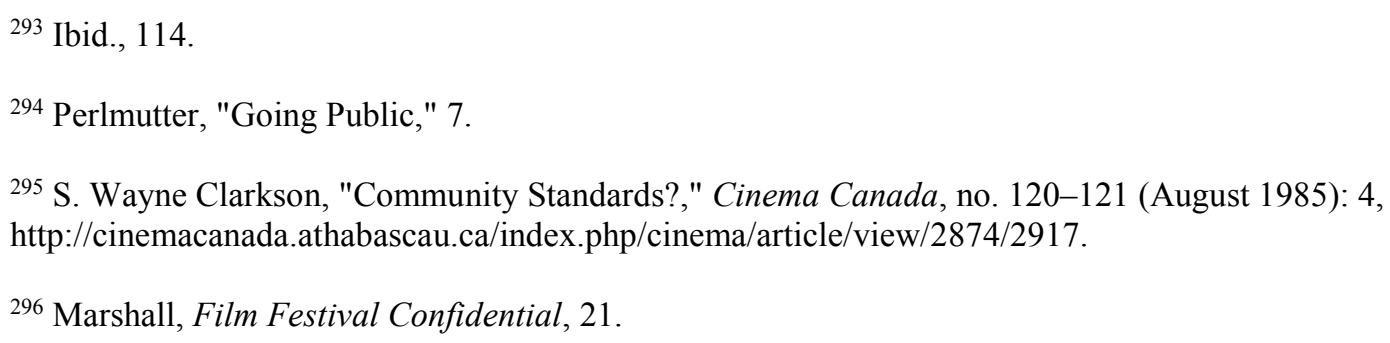


Saskatchewan Board. Festivals are directed to apply for a "General Exemption" to avoid the costs and paperwork of classification.

British Columbia exempts film societies, not festivals, but a festival can organize itself as a film society. For example, the Vancouver International Film Festival is operated by the Vancouver International Film Festival Society. Only society members can view the films, but society memberships are sold with film admissions. The cost is two dollars and good for the duration of the festival. $\mathrm{BC}$ requires society members to be at least eighteen. Manitoba requires festival films to be classified, but does not charge a fee, and does not ban or cut any film. Nova Scotia requires festival films to be classified, but allows the festival itself to do this and then submit supporting documentation to the agency. ${ }^{297}$

Hounddog played at a festival film in Ontario. As per Ontario regulations, it was exempt from classification, provided the audience was limited to age eighteen and over. The exemption from classification conditional on age restriction, as permitted in Ontario and British Columbia, is a two edged sword: It saves the festival time and money, but limits attendance. ${ }^{298}$ The festival showings of the unrated Hounddog in the United States were open to anyone, and the Restricted theatrical release allowed children to attend if accompanied by adults, but the festival showing in Ontario was limited to adults only. This makes the Canadian exhibition even more restricted than the perhaps unfairly limited showings in the United States. However, a festival showing in several other

\footnotetext{
${ }^{297}$ Rules for rating festival films were obtained from the web sites of the film classification agencies, except for Nova Scotia, which does not post this information. Nova Scotia's rules were obtained by personal communications with a member of the agency and an associate of the Atlantic Film Festival.

298 The self-classification performed in Nova Scotia has a similar risk. Just as the MPAA may be more restrictive than necessary to avoid government censorship, a film festival in Nova Scotia may err on the side of caution when classifying their films.
} 
provinces would have been open to anyone, and the festival did have the option of requesting a classification.

\section{After the Festival}

When Hounddog was released on DVD, rating was mandatory in the four jurisdictions that classify home video. All of them classified it significantly lower than the effective Restricted that applied when it was shown at the Female Eye Festival in Toronto: 14A in Manitoba, Ontario, and Nova Scotia; 13+ in Quebec. These ratings are also lower, or more liberal, than the Restricted rating from the MPAA.

A home video classification can be more restrictive than the festival showing. As Alberta and Quebec do not have age restrictions for festival films, a film might be open to anyone at a festival there, then age restricted for theatrical or home video release. A festival's self-rated film in Nova Scotia might get a higher rating when classified by the Board there. The Ontario Board requested cuts to Baise-moi and Fat Girl (Catherine Breillat, 2001) for theatrical release, even though they had played uncut at festivals. Baise-moi was cut, but Fat Girl was eventually released uncut.

\subsection{Conclusion}

Films at film festivals in the United States do not require classification. They are exempt from classification in most provinces, though in some cases they are automatically Restricted. The reasons for exemption are different: The MPAA ignores these films as they are not major studio productions, while the Canadian agencies exempt these films as they are not for the general public, or at least not for children. In the United 
States and Canada, festival films have the option of obtaining a classification to avoid being unrated or automatically Restricted, respectively.

The countries differ when these films go into theatrical release or home video. In the United States, the MPAA is likely to give a higher rating than a major studio film with the same content. In Canada, already with lower ratings, the rating is less likely to be influenced by the independent origins of the film. However, the rating can be higher or lower than the effective rating of a festival showing, most agencies have the right to ban or edit a film that has shown uncut at a festival, and a distributor may choose to cut a film in order to obtain a desired rating. The home video release of Hounddog was rated more liberally in Canada than in the United States, as is common with mainstream films. Conversely, the Ontario festival showing was more restricted than the festival showings and theatrical showings in the United States. 


\section{Conclusion}

Classifications and advisories identify films for age appropriateness and warn of possibly objectionable content. A film maker's desire to obtain a specific classification can lead to self-censorship, and the classification process reveals concerns of the agencies, the governments and industry groups that operate them, and persistent issues in film censorship. As shown in chapter two, there are gaps in the literature on film rating systems, particularly in Canada.

Chapter three explored the different paths to the current film rating systems in Canada and the United States. Both countries have similar origins of film censorship, but in the United States the mainstream film industry had enough power and influence to regulate itself, and has long used the spectre of government censorship to maintain that power. It has also reinforced that power by being stricter than government might be, to its own films and even more to films made outside of the mainstream.

Chapter four continued the history through the legalization of adult sex films, and the development of the adult sex feature film. The changes to obscenity law that allowed legalization were generated by both mainstream films and adult sex films. Canada's Butler test for obscenity came much later than the equivalent American Miller test, and offers greater legitimacy to sex films, but pays more attention to the potential harm of pornography.

Censorship by Canadian agencies has never been tested at the Supreme Court under the Charter of Rights and Freedoms. Constitutional challenges to the censorship powers of the Ontario Film Review Board have succeeded twice, but have only resulted in incremental adjustments to legislation. 
Chapter five described the current operations of the rating agencies, revealing the industry dominance of the MPAA system, and the different approaches across Canada, both in the scope and operations of the agencies.

Chapter six reviewed the classifications assigned to the top 100 theatrical releases of 2013. This review showed that most MPAA classifications are more restrictive than Canadian classifications, at every level. Within Canada, the agencies assign similar classifications to most films. Where there are differences, BC and Quebec are the most liberal agencies, Alberta and Manitoba are the most restrictive, and Ontario and Nova Scotia are close to average.

The case study of Avatar, chapter seven, explored the ratings process for mainstream films in greater detail. It is an example of a film with generally lower ratings in Canada than in the United States, and provincial differences in the case of BC's higher rating. This chapter also drew on semiotics to note how different agency circumstances affect understanding film content for determining ratings, and how ratings themselves subsequently affect understanding of the film text.

Chapter eight is a case study of the adult sex film Pirates. Adult Sex Films have been legal in both Canada and the United States for several years, but are only classified in Canada. The classification of these films provides little direct benefit to consumers, but is a source of income to the agencies, provides some regulatory control of the industry, and ensures classifiers are not unduly shocked by sexual activity in a mainstream film.

Chapter nine discusses the rating process for smaller films typical of film festivals, using the example of Hounddog. Canadian ratings, already more liberal than American ratings, have been shown by careful analysis to be fairer to films that do not 
originate with the major studios. However, the practice of not ratings films at festivals, then rating them for general release, can result in an inconsistent approach to content.

The analysis of classifications assigned to the most popular films of 2013 demonstrates that more liberal classification are usually assigned by Canadian classification agencies than by the American MPAA, at every level. The review of the history and operations of the agencies identifies a number of factors responsible for Canadian liberalism:

- Early adoption of special rules for children

- Early use of age ratings and content advisories

- Classifiers' exposure to a greater range of films

- Independence from the major studios

- Public accountability, and

- A mandate to serve the population at large, not just parents.

Some of these factors might be overcome by an industry system, but not all, so, in a democracy, a government run classification or censorship agency can be less restrictive than one run by industry. This is a lesson worth keeping in mind as proposals for internet censorship are discussed, and powerful online companies such as Google and Facebook censor their own content.

The effect of government run classification on adult sex films is less clear. Obscenity law generally changes in response to court cases after a film has been shown and charged, and the prior restraint of government film classification in Canada delayed changes to obscenity laws. When those changes finally came, they reflected more contemporary concerns of harm rather than explicitness, though there is disagreement about what constitutes harm. Unlike the United States, Canada's obscenity law states what is permitted as well as what is not permitted, and has established the community to 
consider. This ensures many films that are potentially subject to obscenity charges in the United States run no such risk in Canada. On the other hands, the law encourages classification agencies to prevent some scenarios from appearing in sex films in Canada. The voluntary application of federal obscenity law in provincial film classification is inconsistent within and among the agencies. This may be not so much a reflection on the operations of the agencies as an illustration of how difficult it is to craft obscenity laws that meet conflicting public demands.

Independent and festival films can play unrated in Canada and the United States, but may face audience restrictions in Canada, and venue and advertising restrictions in the United States. When and if they obtain classification, it is likely to be lower in Canada.

The various provincial ratings agencies usually assign classifications that have more in common with each other than with American ratings. Even Quebec's distinct system leads to classifications similar to the other provinces for eighty percent of films. If any nationalist reassurance is needed, when it comes to film classification, the different provinces are more like each other than different, and all are different from the United States.

Where there are differences in classification, they do not appear to be due to the different structures and operations of the agencies, nor the existence or types of guidelines. It does appear that the scope of the agency affects ratings. Alberta, the most restrictive agency, and like the more restrictive MPAA, does not classify any home video, including adult sex films. This might be considered a sign of a libertarian approach, where respect for individual rights allows total freedom of home viewing, but it can also 
be considered a socially conservative refusal to legitimize adult sex films by including them in a regulatory process. British Columbia, the most liberal agency, does not classify home video either, but does classify adult sex films.

It also appears that agencies with full time employees make more consistent decisions than agencies with part-time board members. More consistent decisions are not necessarily more representative of the population. Neither employees nor board members are more likely to represent the population, but all of the agencies have some degree of obtaining public feedback, and ultimately answer to elected officials.

Though much more accountable and transparent than the MPAA, the provincial film classification agencies do occasionally obscure aspects of their operations. Some records are unavailable, lost, or costly to obtain, and some information is not available. This appears to be oversight and underfunding rather than a deliberate attempt to conceal. In the context of government operations, an agreement with a film distributor to cut a few seconds of film in exchange for a preferred rating is a minor matter. That this is done secretly, and apparently accepted by the public, are both causes for concern. Canada's Charter of Rights and Freedoms limits free speech so long as the limits are reasonable and justified, but if a film scene is quietly cut to avoid a ban, the limitation of speech is not even noticed, let alone shown to be reasonable and justified. Agencies in other countries are able to provide information about all post-production cuts, and this would be desirable in Canada.

Portrayals of female sexuality are a persistent issue in censorship and classification. From the Spanish dancer film banned in 1894 to In Praise of Older Women to recent productions including Pirates and Hounddog, it is questions of female sexuality 
in films that have repeatedly driven public concerns, classification decisions, and obscenity cases. The Butler decision enshrined concern about harm to women in sexually explicit materials. A potential area to investigate may be whether female sexuality is a greater concern simply because it is more often explored in film, or if there is more attention paid to it. Either way, there is a frequent desire to either suppress female sexuality completely, or direct it into appropriate forms, another type of suppression. It is simplistic to blame this on male dominance of the film industry, as classification laws have input from women, and the agencies have historically ensured gender balanced film review panels.

It is noteworthy that community standards are legally enshrined as a consideration for obscenity law in Canada and the United States, despite concerns about the appropriateness of this from people concerned about representations of women. This affects the approval of films adult films in Canada. In addition, the notion of community standards is used throughout the range of ratings, despite various studies suggesting a more scientific approach to protecting children, and concerns about harm to women demonstrated in mainstream films. It is also curious that Canada's federal obscenity law considers the community to be the entire country, while the film classification systems consider the community to be the province.

Most countries that rate films have systems similar to Canada and the United States. Canada is unusual for having classification at the provincial level, particularly as that leaves some areas without any film classification. Many jurisdictions have more age restricted classifications than Canada. For example, instead of $13+$ or $14 \mathrm{~A}$, the British Board of Film Classification has 12A (under 12 requires adult accompaniment, theatres 
only), 12 (no admission or sale/rental to persons under 12) and 15 (no admission or sale/rental to persons under 15).

Though Canada's ratings are more liberal than the MPAA's, they are not necessarily better. It is hard to claim that any film ratings system is better, partly because there is very little work comparing systems. Filmmakers, exhibitors, and audiences all support classification, but within and among each group there are disagreements about what an ideal classification system would be. However, fears that a government run system must be repressive are unfounded. 


\section{Appendix A: Quebec Labels}

Avatar DVD stickers in Quebec, on the disk and case, as well as the printed (and contradictory) CHVRS and Quebec classifications on the case.
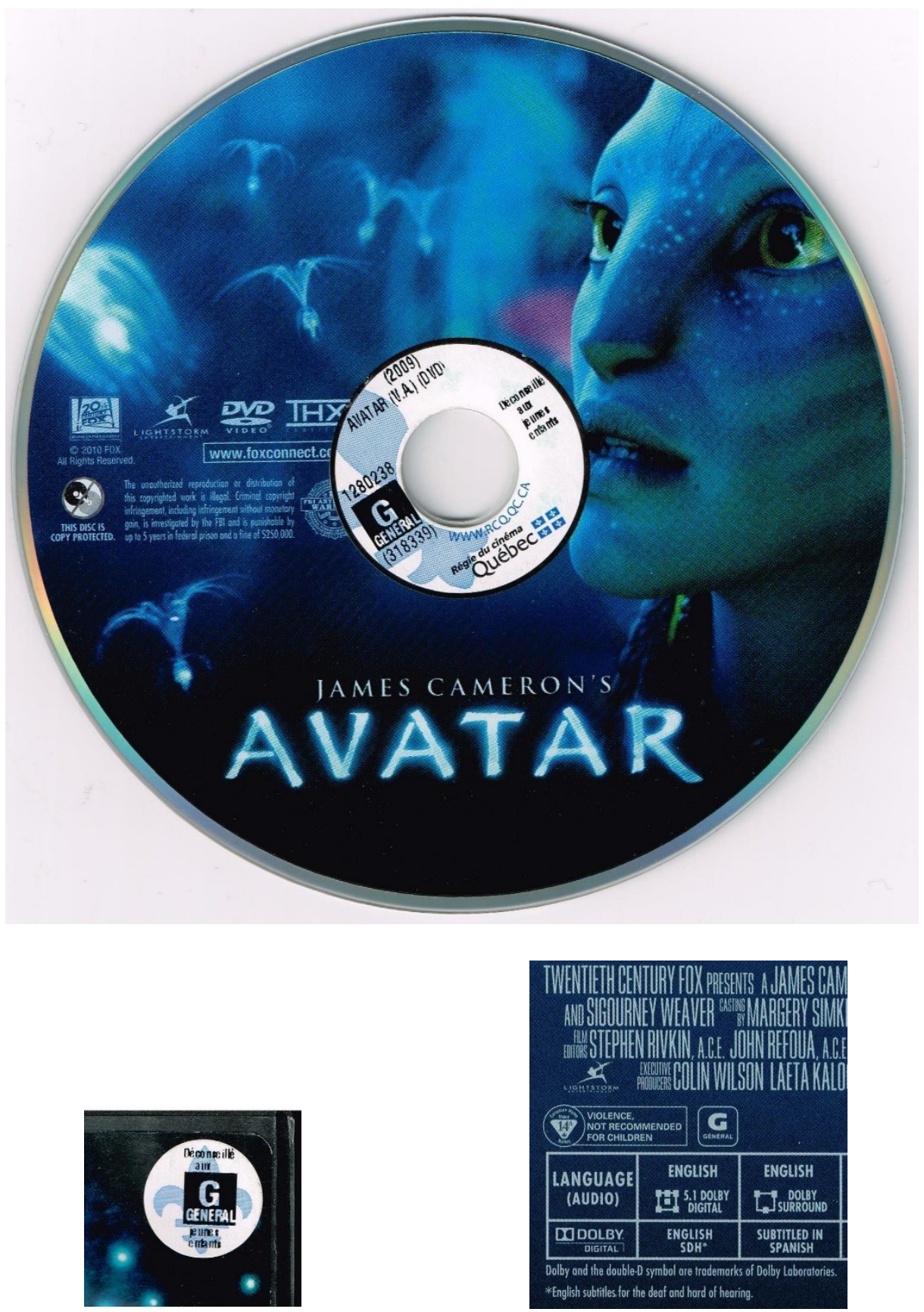


\section{Appendix B: Ontario Guidelines Summary Handout}

\begin{tabular}{|c|c|c|c|c|c|c|}
\hline \multicolumn{7}{|c|}{ Quick Reference Guide To The Elements } \\
\hline & General & $\begin{array}{ll}\text { PC } & \text { Parental } \\
\text { Guidance }\end{array}$ & $14^{A} \quad 14 A$ & $18^{4}$ & Restricted & $\begin{array}{l}\text { POSSIBLE NFO } \\
\text { PIECES }\end{array}$ \\
\hline $\begin{array}{c}\text { Age } \\
\text { Suitability }\end{array}$ & Suitable for All & Parental Guidance Advised & $\begin{array}{l}\text { Persons younger than } 14 \text { must } \\
\text { be accompanied by an Adult. }\end{array}$ & $\begin{array}{l}\text { Persons younger than } 18 \text { must be } \\
\text { accompanied by an adult }\end{array}$ & $\begin{array}{l}\text { Restricted to persons } 18 \text { years } \\
\text { of age or over }\end{array}$ & \multirow{7}{*}{$\begin{array}{l}\text { - Not } \\
\text { Recommended for } \\
\text { Children } \\
\text { - Not } \\
\text { Recommended for } \\
\text { Young Children } \\
\text { - Some Scary } \\
\text { - Scenes } \\
\text { - Cartoon Animation } \\
\text { - Mction } \\
\text { - Mature Theme } \\
\text { - Language May } \\
\text { Offend } \\
\text { - Coarse Language } \\
\text { - Language not } \\
\text { - evaluated } \\
\text { - Subtitied } \\
\text { - Crude Content } \\
\text { - Violence } \\
\text { - Graphic Violence } \\
\text { - Brutal Violence } \\
\text { - Sexual Violence } \\
\text { - Nudity } \\
\text { - Sexual Content } \\
\text { - Explicit Sexual } \\
\text { Content } \\
\text { - Gory Scenes } \\
\text { - Frightening Scenes } \\
\text { - Disturbing Content } \\
\text { - Substance Abuse } \\
\text { - Tobacco Use }\end{array}$} \\
\hline Language & $\begin{array}{l}\text { Infrequent use of mild } \\
\text { profanity such as dam, } \\
\text { damn, hell, ass and } \\
\text { god. }\end{array}$ & 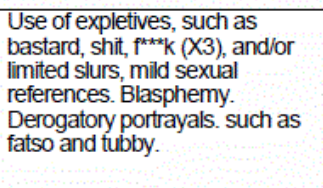 & $\begin{array}{l}\text { Coarse language and/or slurs } \\
\text { directed to specific segments of } \\
\text { society; excessive use of } \\
\text { expletives; sexual references. } \\
\text { Infrequent strong, aggressive } \\
\text { language. Derogatory portrayals } \\
\text { such as lard ass and those. }\end{array}$ & $\begin{array}{l}\text { Very intense and aggressive } \\
\text { coarse language usually } \\
\text { accompanied by violence directed } \\
\text { towards the person(s). } \\
\text { Aggressive/ frequent slurs/sexual } \\
\text { references. }\end{array}$ & No restriction. & \\
\hline $\begin{array}{c}\text { Violence } \\
\text { (see Note 3) }\end{array}$ & $\begin{array}{l}\text { Restrained portrayals } \\
\text { of limited violence } \\
\text { which may result in } \\
\text { extremely limited } \\
\text { bloodletting. }\end{array}$ & $\begin{array}{l}\text { Restrained portrayals of non- } \\
\text { graphic violence. The portrayals } \\
\text { are not prolonged; there are no } \\
\text { close-ups; bloodletting and/or } \\
\text { tissue damage is limited. }\end{array}$ & $\begin{array}{l}\text { Portrayals of graphic violence } \\
\text { resulting in blood-letting and/or } \\
\text { tissue damage which may or may } \\
\text { not be fatal. Violence should be } \\
\text { within the context of the film. }\end{array}$ & $\begin{array}{l}\text { Frequent and/or prolonged } \\
\text { portrayals of graphic violence } \\
\text { resulting in bloodletting and/or } \\
\text { tissue damage. Limited instances } \\
\text { of brief, visually explicit portrayals } \\
\text { of violence. Graphic torture/ } \\
\text { brutality. Graphic sexual violence. }\end{array}$ & $\begin{array}{l}\text { Visually explicit portrayals of } \\
\text { violence which may be } \\
\text { characterized by extreme } \\
\text { brutality, extreme bloodletting } \\
\text { and extreme tissue damage, } \\
\text { torture, horror and sexual } \\
\text { violence. }\end{array}$ & \\
\hline Nudity & $\begin{array}{l}\text { Non-sexual nudity with } \\
\text { no close-ups (including } \\
\text { still images.) }\end{array}$ & $\begin{array}{l}\text { Nudity in a non-sexual context, } \\
\text { non-exploitative close-up } \\
\text { (including still images.) }\end{array}$ & $\begin{array}{l}\text { Limited nudity in a brief sexual } \\
\text { situation. }\end{array}$ & $\begin{array}{l}\text { Limited instances of nudity in a } \\
\text { sexual situation. }\end{array}$ & Nudity in a sexual situation. & \\
\hline $\begin{array}{l}\text { Sexual } \\
\text { Activity }\end{array}$ & $\begin{array}{l}\text { Limited embracing and } \\
\text { kissing. }\end{array}$ & $\begin{array}{l}\text { Embracing, kissing; mild sexual } \\
\text { innuendo. }\end{array}$ & $\begin{array}{l}\text { Fondling, implied sexual activity, } \\
\text { sexual innuendo. }\end{array}$ & $\begin{array}{l}\text { Limited instances of simulated } \\
\text { sexual activity. }\end{array}$ & $\begin{array}{l}\text { Simulated sexual activity, } \\
\text { explicit sexual activity. }\end{array}$ & \\
\hline Horror & $\begin{array}{l}\text { Brief moments of mild } \\
\text { horror in comedic, } \\
\text { historic, or fantasy } \\
\text { settings (i.e. dragons, } \\
\text { giants, wicked witches.) }\end{array}$ & $\begin{array}{l}\text { Scenes containing some } \\
\text { grotesque images may be } \\
\text { allowed in a fantasy or comedic } \\
\text { context, but there will be no } \\
\text { detailed and/or prolonged focus } \\
\text { on gory images or suffering. }\end{array}$ & $\begin{array}{l}\text { Occasional gory moments and } \\
\text { some horrific/grotesque images, } \\
\text { but these will not be detailed. }\end{array}$ & $\begin{array}{l}\text { Gory or grotesque imagery may } \\
\text { be more frequent or detailed, but } \\
\text { will generally avoid prolonged } \\
\text { focus. }\end{array}$ & $\begin{array}{l}\text { Frequent detailed goryl } \\
\text { grotesque images will have a } \\
\text { more prolonged or graphic } \\
\text { focus and greater frequency. }\end{array}$ & \\
\hline $\begin{array}{l}\text { Psychological } \\
\text { Impact } \\
\text { (see Note 2) }\end{array}$ & $\begin{array}{l}\text { Sensitive to scenes or } \\
\text { situations related to a } \\
\text { child's sense of security } \\
\text { and well-being. }\end{array}$ & $\begin{array}{l}\text { Scenes and situations that may } \\
\text { cause adverse psychological } \\
\text { impact on children. May include } \\
\text { frightening or emotionally } \\
\text { upsetting situations involving } \\
\text { threats, injury, illness, family } \\
\text { problems, or death to young } \\
\text { people, family member, and } \\
\text { animals (particularty pets.) } \\
\text { Bullying. Substance referencing. } \\
\text { Visual reference. Crude } \\
\text { Content. }\end{array}$ & $\begin{array}{l}\text { Occasional upsetting scenes that } \\
\text { will tend to be more frightening, } \\
\text { intense, disturbing - particularly to } \\
\text { younger viewers. Substance } \\
\text { abuse. Frequent substance } \\
\text { referencing. }\end{array}$ & $\begin{array}{l}\text { Frequent upsetting, disturbing, or } \\
\text { fightening scenes that may cause } \\
\text { adverse psychological impact on } \\
\text { some mature viewers. Detaled/ } \\
\text { graphic portrayals of substance } \\
\text { abuse. }\end{array}$ & $\begin{array}{l}\text { Scenes and situations may } \\
\text { cause extreme adverse } \\
\text { psychological impact. May } \\
\text { involve intense and compelling } \\
\text { terror, acts of degradation, } \\
\text { threats of violence, and } \\
\text { continuous acts of violence; } \\
\text { situations could be } \\
\text { accompanied by coarse, } \\
\text { abusive, and degrading } \\
\text { dialogue. Explicit substance } \\
\text { abuse. }\end{array}$ & \\
\hline \multicolumn{7}{|c|}{ Note 1: From time to fime, guidelines may be set aside at the Panel's discretion (where social, historic and documentary significance warrants). The reason is to be identified on the Summary Report. } \\
\hline \multicolumn{7}{|c|}{$\begin{array}{l}\text { Note 2: Psychological impact may be a state of mind, mood or feeling and/or other effects on the viewer, resulting from the treatment of scenes and situations within the flim. Treatment may include intensity, degree, pace, atmosphere, tone, } \\
\text { visual effects, and dialogue. }\end{array}$} \\
\hline \multicolumn{7}{|l|}{ Note 3: } \\
\hline
\end{tabular}

PRE-001 R20 July 2012 


\section{Bibliography}

"Adult-Film Distributor Takes Nova Scotia to Court." The Globe and Mail. November 12, 2009, sec. Arts. http://www.theglobeandmail.com/arts/adult-film-distributortakes-nova-scotia-to-court/article4196426/.

Bangay, Autumn. "Legal Child Pornography: The Influence of Sexually Provocative Images of Children on Adult Attitudes toward Child Sexual Abuse." Honours Diss, Cape Breton University, 2006.

"BC Archives: Detailed Finding Aid GR-0490." Accessed January 7, 2015. http://royalbcmuseum.bc.ca/bcarchives/.

Bell, Tom W. Internet Privacy and Self-Regulation: Lessons from the Porn Wars. Cato Institute, August 9, 2001.

http://gateway.proquest.com.proxy.library.carleton.ca/openurl?url_ver=Z39.88-

2004\&res_dat=xri:policyfile\&rft_dat=xri:policyfile:article:00042670.

"Box Office Mojo," March 25, 2014. http://www.boxofficemojo.com/.

Boyce, Bret. Obscenity and Community Standards. SSRN Scholarly Paper. Rochester, NY: Social Science Research Network, June 1, 2008. http://papers.ssrn.com/abstract=1418684.

Boyle, James. "Foucault in Cyberspace: Surveillance, Sovereignty, and Hardwired Censors." University of Cincinnati Law Review 66 (January 1, 1997): 177-205.

Brand, Jeffrey. A Comparative Analysis of Ratings, Classification and Censorship in Selected Countries around the World. Australia: Centre for New Media Research and Education, Bond University., 2002.

http://epublications.bond.edu.au/cgi/viewcontent.cgi?article $=1886 \&$ context $=\mathrm{hss}$ pubs.

Brand, J., and M. Finn. "Informing Our Own Choices: A Proposal for User-Generated Classification." Media International Australia, no. 130 (February 2009): 112-26.

"British Films Smuttier, Can. Censor Says." Variety. June 27, 1937.

Brody, Dansky, Rubin v. The Queen (1962) SCR 681. Accessed January 7, 2015.

"Canadian Broadcast Standards Council." Ratings Classifications. Accessed January 6, 2015. http://www.cbsc.ca/english/agvot/ratings.php.

"Canuxploitation! Your Complete Guide to Canadian B-Film." Accessed January 9, 2015. http://www.canuxploitation.com/.

"Christian Spotlight on Entertainment." Films for Christ / Christian Answers Net. Accessed January 9, 2015. http://christiananswers.net/spotlight/.

Clarkson, S. Wayne. "Community Standards?" Cinema Canada, no. 120-121 (August 1985).

http://cinemacanada.athabascau.ca/index.php/cinema/article/view/2874/2917.

"ClearPlay Movies." ClearPlay. Accessed January 9, 2015. http://www.clearplay.com.

Cole, A. O. C. Trent: The Making of a University, 1957-1987. Peterborough, Ont.: Trent University, 1992. http://www.trentu.ca/library/archives/88-016.htm.

Consumer Protection BC. 2011 Annual Report: Administration of the Motion Picture Act. Accessed January 19, 2015.

http://www.consumerprotectionbc.ca/images/content/publications/2011\%20mpa\% 
20administration $\% 20$ agreement $\% 20$ report $\% 20$ -

$\% 20$ consumer $\% 20$ protection $\% 20$ bc.pdf.

. "Motion Pictures." Consumer Protection BC. Accessed January 19, 2015. http://www.consumerprotectionbc.ca/motion-pictures-portal.

Couvares, Francis G. "Hollywood, Main Street, and the Church: Trying to Censor the Movies before the Production Code." In Movie Censorship and American Culture, edited by Francis G. Couvares, Second edition., 129-58. Amherst: University of Massachusetts Press, 2006.

Cramer, Joe. "'Avatar' Draws Controversy from the Vatican." The Villanovan. Accessed January 5, 2015. http://www.villanovan.com/news/view.php/145596/Avatardraws-controversy-from-the-Vatica.

Crichton, Michael. Westworld. Bantam, 1974.

Cridlin, Jay. "Yo Ho, Yo Ho ... Oh No!" Tampa Bay Times. January 18, 2006. http://www.sptimes.com/2006/01/18/Tampabay/Yo_ho_yo_ho_oh_no.shtml.

Dean, Malcolm. Censored! Only in Canada: The History of Film Censorship - The Scandal Off the Screen. Toronto: Virgo, 1981.

Devine, Siobhan. My Tango with Porn. VHS, Documentary, 2003.

Dick, Kirby. This Film Is Not Yet Rated, 2006.

Dines, Gail, Bob Jensen, and Ann Russo. Pornography: The Production and Consumption of Inequality. New York: Routledge, 1997.

Dominion News \& Gifts (1962) Ltd. v. The Queen [1964] SCR 251. Accessed January 7, 2015.

Ebert, Roger. "Emmanuelle Movie Review \& Film Summary," January 1, 1975. http://www.rogerebert.com/reviews/emmanuelle-1975. . "'Hounddog' Movie Review \& Film Summary." Accessed December 20, 2015. http://www.rogerebert.com/reviews/hounddog-2008.

Franklin, Daniel. "Avatar: The Plot, the Controversy, the Irony." Encyclopedia Britannica. Accessed January 20, 2015. http://www.britannica.com/blogs/2010/01/avatar-the-plot-the-controversy-theirony.

Friedman, May. "Working Out the Kinks : Advancing the Pornography Debate." ProQuest, UMI Dissertations Publishing, 2002. https://curve.carleton.ca/theses/26514.

Gillespie, Jack. "Private U.S.A. Sets Release Date For Multimillion-Dollar Feature, Millionaire." AVN - Business. Accessed January 20, 2015.

http://business.avn.com/articles/video/Private-U-S-A-Sets-Release-Date-ForMultimillion-Dollar-Feature-Millionaire-40243.html.

Goldstein, Sidney E. "The Motion Picture and Social Control." In The Movies on Trial: The Views and Opinions of Outstanding Personalities Anent Screen Entertainment Past and Present, edited by William J. Perlman, 206-31. New York: MacMillan, 1936.

Government of Alberta. "Alberta Film Ratings." Alberta - Culture and Tourism. Accessed January 19, 2015. http://www.albertafilmratings.ca/.

Government of Manitoba. "Manitoba Film Classification Board." Manitoba - Tourism, Culture, Heritage, Sport and Consumer Protection. Accessed January 9, 2015. http://www.gov.mb.ca/chc/mfcb/index.html. 
Government of New Brunswick. "Film Exchange Licence," 11:08:36.0.

http://www2.gnb.ca/content/gnb/en/services/services_renderer.835.Film_Exchang e Licence.html.

Government of Prince Edward Island. "Film Classification." Prince Edward Island: Department of Environment, Labour and Justice. Accessed January 19, 2015. http://www.gov.pe.ca/jps/index.php3?number=20822\&lang=E.

Government of Quebec. "Régie Du Cinéma." Accessed January 19, 2015. http://www.rcq.gouv.qc.ca/.

Government of Saskatchewan. "Film and Video Classification Board." Ministry of Justice - Branches, Boards and Commissions. Accessed January 19, 2015. http://www.justice.gov.sk.ca/filmandvideoclassification.

Greene, Ray. "Hounddog." Boxoffice 143, no. 3 (March 2007): 64-65.

Haberski, Jr. Raymond J. Freedom to Offend: How New York Remade Movie Culture. Lexington: The University Press of Kentucky, 2007.

Hall, Ann C., and Mardia J. Bishop, eds. Pop-Porn: Pornography in American Culture. Westport, Conn: Praeger, 2007.

Hall, Stuart. "Encoding/Decoding." In Culture, Media, Language: Working Papers in Cultural Studies 1972-79, 117-27. London: Routledge, 1991.

Hare, Breeanna. "'Avatar' Sex Scene on DVD?." Accessed January 20, 2015. http://marquee.blogs.cnn.com/2010/01/06/avatar-sex-scene-on-dvd/.

Heaven, Will. "James Cameron's Avatar Is a Stylish Film Marred by Its Racist Subtext." News - Telegraph Blogs, December 22, 2009. http://blogs.telegraph.co.uk/news/willheaven/100020488/james-camerons-avataris-a-stylish-film-marred-by-its-racist-subtext/.

Holquist, Michael. "Introduction: Corrupt Originals: The Paradox of Censorship." PMLA 109, no. 1 (January 1, 1994): 14-25.

Hutchinson, Allan C., and Klaus Petersen. Interpreting Censorship in Canada. University of Toronto Press, 1999.

Internet Movie Database. "Avatar." Internet Movie Database. Accessed January 20, 2015. http://www.imdb.com/title/tt0499549/?

Jacobellis v. Ohio 378 U.S. 184 (1964).

Jenkins v. Georgia 418 U.S. 153 (1974).

Jennings, David. Skinflicks: The Inside Story of the X-Rated Video Industry. Bloomington, IN.: Authorhouse, 2000.

Jochelson, Richard. "After Labaye: The Harm Test of Obscenity, the New Judicial Vacuum, and the Relevance of Familiar Voices." Alberta Law Review 46, no. 3 (2009): 741-67.

Johnson, Brian. Brave Films, Wild Nights: 25 Years of Festival Fever. Random House Canada, 2000.

Johnson, Kirsten K. Undressing the Canadian State: The Politics of Pornography from Hicklin to Butler. Halifax: Fernwood Pub, 1995.

Joone. Pirates, 2005.

"Joseph Burstyn, Inc. v. Wilson 343 U.S. 495 (1952)." Justia Law. Accessed January 7 , 2015. https://supreme.justia.com/cases/federal/us/343/495/.

Jowett, Garth. "'A Significant Medium for the Communication of Ideas:' The Miracle Decision and the Decline of Motion Picture Censorship, 1952-1968." In Movie 
Censorship and American Culture, edited by Francis G. Couvares, Second edition., 258-76. Amherst: University of Massachusetts Press, 2006.

Kampmeier, Deborah. "Deborah Kampmeier." Full Moon Films. Accessed December 20, 2014. http://fullmoonfilmsny.com/2010/12/deborah-kampmeier/.

Kaufman, Jason Andrew. The Origins of Canadian and American Political Differences. Cambridge, Mass. : Harvard University Press, 2009.

Kelly, Deirdre. "An Old Home Gives up Its Secrets." The Globe and Mail. June 13, 2008. http://www.theglobeandmail.com/life/home-and-garden/real-estate/an-old-homegives-up-its-secrets/article674376/.

Keshen, Jeff. Propaganda and Censorship During Canada's Great War. University of Alberta, 1996.

"Kids-In-Mind." Critics / Kids-In-Mind. Accessed January 9, 2015. http://www.kids-inmind.com/.

King, Randall. "FP Critic's Eyes See Avatar in Different, Spectacular Light." Winnipeg Free Press. Accessed January 20, 2015. http://www.winnipegfreepress.com/artsand-life/entertainment/movies/fp-critics-eyes-see-avatar--in-different-spectacularlight-79882357.html.

Kuhn, Annette, and Guy Westwell. A Dictionary of Film Studies. Oxford: Oxford University Press, 2012.

Lee, Raymond. Research on Community Standards. Vancouver: British Columbia Film Classification Office, 2003. www.bcfilmclass.com/publications/cs2004.pdf (Accessed 2005, no longer available).

Leone, Ron, and Laurie Barowski. "MPAA Ratings Creep" 5, no. 1 (February 1, 2011): 53-68.

Leone, Ron, and Nicole Houle. "21st Century Ratings Creep: PG-13 and R" 23, no. 1 (June 1, 2006): 53-61.

Lewis, Jon. Hollywood v. Hard Core: How the Struggle Over Censorship Created the Modern Film Industry. New York: NYU Press, 2002.

Lipset, Seymour Martin. Continental Divide: Values and Institutions of the United States and Canada. New York: Routledge, 1990.

Loiselle, André. Mourir À Tue-Tête / A Scream from Silence. Cinetek Series. Wiltshire, England: Flicks Books, 2000.

. "Subtly Subversive or Simply Stupid: Notes on Popular Quebec Cinema." Post Script XVIII, no. 2 (1999): 75-84.

Lyman, Rick. "Hollywood Balks at High-Tech Sanitizers; Some Video Customers Want Tamer Films, and Entrepreneurs Rush to Comply." The New York Times, September 19, 2002, sec. Movies.

http://www.nytimes.com/2002/09/19/movies/hollywood-balks-high-techsanitizers-some-video-customers-want-tamer-films.html.

Marshall, William. Film Festival Confidential. Toronto: McArthur \& Co, 2005.

McCallum, Jon. Turning Darkness into Light: The Making of Hounddog. DVD. Empire Film Group, 2008.

McCarthy, Todd. "Hounddog." Variety, January 29, 2007.

McGinn, Daniel. "XXX Blue, Spending Green." Newsweek, November 27, 2005. http://www.newsweek.com/xxx-blue-spending-green-115291. 
"Meet the MPAA." Motion Picture Association of America. Accessed January 23, 2015. http://www.mpaa.org/our-story/.

Miller v. California 413 U.S. 15 (1973).

Milter, Katalin Szoverfy, and Joseph W. Slade. "Global Traffic in Pornography: The Hungarian Example." In International Exposure: Perspectives on Modern European Pornography, 1800-2000, edited by Lisa Z. Sigel, 173-204. Piscataway NJ: Rutgers University Press, 2005.

Mosk, Richard M. "Motion Picture Ratings in the United States." Cardozo Arts \& Entertainment Law Journal 15, no. 1 (1997): 135-45.

Motion Picture Association of America, Inc., and National Association of Theatre Owners, Inc. "Classification and Rating Rules," January 1, 2010. http://www.filmratings.com/what.html.

"Movie Mom." Belief Net - Movie Mom. Accessed January 9, 2015. http://www.beliefnet.com/columnists/moviemom.

"Movie Reviews." Catholic News Service. Accessed January 9, 2015. http://www.catholicnews.com/movies.htm.

Moylan, Brian. "The Avatar Na'vi Sex Scene Revealed." Gawker. Accessed January 20, 2015. http://gawker.com/5445676/the-avatar-navi-sex-scene-revealed.

Musser, Charles. Edison Motion Pictures, 1890-1900: An Annotated Filmography. Gemona (UD) Italy; [Washington, D.C.]: Giornate del cinema muto ; Smithsonian Institution Press, 1997.

"Mutual Film Corp. v. Industrial Comm'n of Ohio 236 U.S. 230 (1915)." Justia Law, https://supreme.justia.com/cases/federal/us/236/230/.

Nielson-Stowell, Ameilia. "CleanFlicks Plans to Appeal Ruling." DeseretNews.com, July 9, 2006. http://www.deseretnews.com/article/640193492/CleanFlicks-plans-toappeal-ruling.html?pg=all.

"Observing Older Women." Playboy, October 1978.

"Ontario Board of Censors Chairman's Correspondence," 1911 1921. RG-56-1-1-4. Archives of Ontario.

Ontario Film Review Board. "Classifying Adult Sex Films," 2005.

_. "Classifying Mainstream Films," 2007.

—. Ontario Film Review Board Annual Report 2010/2011, 2011. http://www.ofrb.gov.on.ca/english/Annual\%20Report\%2010-11.pdf.

_. "Ontario Film Review Board Chair's Files," 2005.

Paasonen, Susanna, and Laura Saarenmaa. "The Golden Age of Porn: Nostalgia and History in Cinema." In Pornification: Sex and Sexuality in Media Culture, edited by Kaarina Nikunen, Susanna Paasonen, and Laura Saarenmaa, 23-32. Oxford ; New York: Bloomsbury Academic, 2008.

Parent Previews. "Avatar." Parent Previews. Accessed January 20, 1015. http://parentpreviews.com/movie-reviews/avatar.

Perlman, William J. "Why This Book?" In The Movies on Trial: The Views and Opinions of Outstanding Personalities Anent Screen Entertainment Past and Present, edited by William J. Perlman, vii - xi. New York: MacMillan, 1936.

Perlmutter, Tom. "Going Public: Mary Brown and the Ontario Film Review Board." Cinema Canada, no. 117 (April 1985): 6-10. 
Phillips, Michael. "Not Suitable in Dallas : Movies: Dentist Fred Aurbach Presides over the Only Big-City Film Ratings Board in the Country--a Thorn in Distributors' Sides." Los Angeles Times. Accessed August 28, 2014.

http://articles.latimes.com/1990-09-18/entertainment/ca-817_1_classificationboard.

Province of Nova Scotia. "Access Nova Scotia - Film and Video." Service Nova Scotia. Accessed January 19, 2015. http://www.novascotia.ca/sns/access/alcoholgaming/theatres-amusements.asp.

"Re: Bengal Tiger," September 11, 1936. GR-490 Box 5. Archives of British Columbia.

"Re: Bride of Frankenstein," May 22, 1935. GR-490 Box 5. Archives of British Columbia.

Regina v. R. Price 20040423 BCPC 0103, (British Columbia 2004).

"Rejection List for the Week Ending April 11, 1914," April 11, 1914. GR-490 Box 8. Archives of British Columbia.

Re Ontario Film and Video Appreciation Society and Ontario Board of Censors (1983) 41 O.R. (2d) 583, (Ontario High Court 1983).

Re Ontario Film and Video Appreciation Society and Ontario Board of Censors (1984) 45 O.R. (2d) 80 (C.A.), (Supreme Court of Ontario 1984).

"Re: The Outlaw - Approved with Cut," October 8, 1946. GR-490 Box 6. Archives of British Columbia.

"Re: The Outlaw - Protests," November 4, 1946. GR-490 Box 6. Archives of British Columbia.

"Roth v. United States 354 U.S. 476 (1957)." Justia Law, https://supreme.justia.com/cases/federal/us/354/476/case.html.

Rotten Tomatoes. "Avatar." Rotten Tomatoes. Accessed November 6, 2014. http://www.rottentomatoes.com/m/avatar/.

R. v. Butler [1992] 1 SCR 452.

R. v. Glad Day Bookshops Inc., (C 2004).

R. v. Hicklin [1868] LR 3 QB 360, (1868).

R. v. Labaye [2005] 3 SCR 728.

Sandler, Kevin S. The Naked Truth: Why Hollywood Doesn't Make X-Rated Movies. New Brunswick, N.J: Rutgers University Press, 2007.

Schaefer, Eric. Bold! Daring! Shocking! True: A History of Exploitation Films, 19191959. Durham: Duke University Press Books, 1999.

_. "Gauging a Revolution: 16mm Film and the Rise of the Pornographic Feature." In Porn Studies, 370-400. Durham: Duke University Press Books, 2004.

Schreiner, Mark. "Republican: Scripts Need Reviewing." StarNewsOnline.com. Accessed January 21, 2015.

http://www.starnewsonline.com/article/20070126/NEWS/701260363.

Scott, A. O. "Theater Will Ignore NC-17 Rating for 'Blue Is the Warmest Color."' ArtsBeat. Accessed January 21, 2015. http://artsbeat.blogs.nytimes.com/2013/10/23/theater-will-ignore-nc-17-ratingfor-blue-is-the-warmest-color/.

"Screenit." Accessed January 9, 2015. http://www.screenit.com/.

Sigel, Lisa Z. International Exposure: Perspectives on Modern European Pornography, 1800-2000. New Brunswick, N.J: Rutgers University Press, 2005. 
"Introduction: Issues and Problems in the History of Pornography." In International Exposure: Perspectives on Modern European Pornography, 18002000, edited by Lisa Z. Sigel, 1-26. Piscataway NJ: Rutgers University Press, 2005.

Sirove, Taryn. "Freedom, Sex \& Power: Film/Video Regulation in Ontario." Wreck: Graduate Journal of Art History, Visual Art, and Theory 2, no. 1 (2008): 31-54.

Smith, Clarissa. "A Perfectly British Business: Stagnation, Continuities, and Change on the Top Shelf." In International Exposure: Perspectives on Modern European Pornography, 1800-2000, edited by Lisa Z. Sigel, 146-73. Piscataway NJ: Rutgers University Press, 2005.

Stanley v. Georgia 394 U.S. 557 (1969).

Stephens, Thomas. "Film Commission Aims to Clear up Royal Mess." SWI Swissinfo.ch, February 28, 2011. http://www.swissinfo.ch/eng/film-commission-aims-to-clearup-royal-mess/29606612.

Strossen, Nadine. Defending Pornography: Free Speech, Sex, and the Fight for Women's Rights. New York: Scribner, 1995.

Talbot, Henry. Comparing Classifications: Feature Films and Video Games 2012 \& 2013. Wellington, New Zealand: Information Unit at the Office of Film and Literature Classification, 2014. www.censorship.govt.nz.

Tatiana. "Why Do We Have 40,000 Adult DVDs in Our Office?" Consumer Protection $B C$. Accessed January 17, 2015. http://www.consumerprotectionbc.ca/component $/ \mathrm{k} 2 /$ item/45-adult_dvd_seizure.

"The Hunger Games (2011)." British Board of Film Classification. Accessed November 22, 2014. http://www.bbfc.co.uk/releases/hunger-games-2011.

"The Laurier Palace Theatre Fire," May 22, 2010. http://silenttoronto.com/?p=92.

"The Restricted Cougar." Consumer Protection BC. Accessed January 12, 2015. http://www.consumerprotectionbc.ca/consumers-film-and-videohomepage/consumer-tips/1028.

Thompson, Kimberly M, and Fumie Yokota. "Violence, Sex, and Profanity in Films: Correlation of Movie Ratings With Content." Medscape General Medicine 6, no. 3 (July 12, 2004). http://www.ncbi.nlm.nih.gov/pmc/articles/PMC1435631/.

Tracey, Grant. "Crosscuts: Brief DVD Reviews - Hounddog." The North American Review 294, no. 5 (September 1, 2009): 45.

Tropiano, Stephen. Obscene, Indecent, Immoral \& Offensive: 100+ Years of Censored, Banned, and Controversial Films. New York: Limelight Editions, 2009.

"United States v. Paramount Pictures, Inc. 334 U.S. 131 (1948)." Justia Law, https://supreme.justia.com/cases/federal/us/334/131/case.html.

Véronneau, Pierre. "When Cinema Faces Social Values: One Hundred Years of Film Censorship in Canada." In Silencing Cinema: Film Censorship around the World, edited by Daniel Biltereyst and Roel Vande Winkel, Kindle., 49-52. New York, New York: Palgrave Macmillan, 2013.

"VideoCanada.com DVD Movies." Accessed January 7, 2015. http://www.videocanada.com/catalog2/index.php?cPath=1.

Waguespack, David M., and Olav Sorenson. "The Ratings Game: Asymmetry in Classification." Organization Science 22, no. 3 (June 1, 2011): 541-53. doi:10.1287/orsc.1100.0533. 
Walsh, David A., and Douglas A. Gentile. "A Validity Test of Movie, Television, and Video-Game Ratings." Pediatrics 107, no. 6 (June 1, 2001): 1302-8. doi:10.1542/peds.107.6.1302.

Waltman, Max. "Rethinking Democracy: Legal Challenges to Pornography and Sex Inequality in Canada and the United States." Political Research Quarterly 63, no. 1 (March 2010): 218-37.

Ward, Kate, and Henry Talbot. Comparing Classifications: Feature Films and Video Games 2010 \& 2011. Wellington, New Zealand: Information Unit at the Office of Film and Literature Classification, 2013. www.censorship.govt.nz.

White, Amy E. Virtually Obscene: The Case for an Uncensored Internet. Jefferson, N.C: McFarland \& Company, 2006.

"Why: History of Ratings." filmRatings.com The Classification \& Ratings Administration. Accessed January 19, 2015. http://www.filmratings.com/.

Williams, Linda. Hard Core: Power, Pleasure, and the "Frenzy of the Visible." Expanded edition. Berkeley: University of California Press, 1999.

_. , ed. Porn Studies. Durham: Duke University Press Books, 2004. - Screening Sex. Durham: Duke University Press, 2008.

Wilson, Barbara J., Daniel Linz, and Barbara Randall. "Applying Social Science Research to Film Ratings: A Shift from Offensiveness to Harmful Effects." Journal of Broadcasting \& Electronic Media 34, no. 4 (September 1, 1990): 44368. doi:10.1080/08838159009386754.

Winslow, Ben. "'Hounddog' Not Porn, A.G. Says." DeseretNews.com, January 26, 2007. http://www.deseretnews.com/article/655191420/Hounddog-not-porn-AGsays.html?pg=all.

Wise, Wyndham. "History of Ontario's Film Industry, 1896 to 1985." Take One, 2000. 216183924. ProQuest. http://proxy.library.carleton.ca/login?url=http: //search.proquest.com.proxy.library.carleton.ca/docview $/ 216183924$ ?accountid=9894.

Wyatt, Justin. "The Stigma of X: Adult Cinema and the Institution of the MPAA Ratings System." In Controlling Hollywood: Censorship and Regulation in the Studio Era, edited by Matthew Bernstein, 238-63. New Brunswick, N.J: Rutgers University Press, 1999.

Yang, Ni, and Daniel Linz. "Movie Ratings and the Content of Adult Videos: The SexViolence Ratio." Journal of Communication 40, no. 2 (January 1990): 28-42.

York, Frank, and Jan LaRue. Protecting Your Child in an X-Rated World. Focus on the Family. Wheaton, Ill: Tyndale, 2002. 